I N T ER N ATIONAL MONETARY FUND

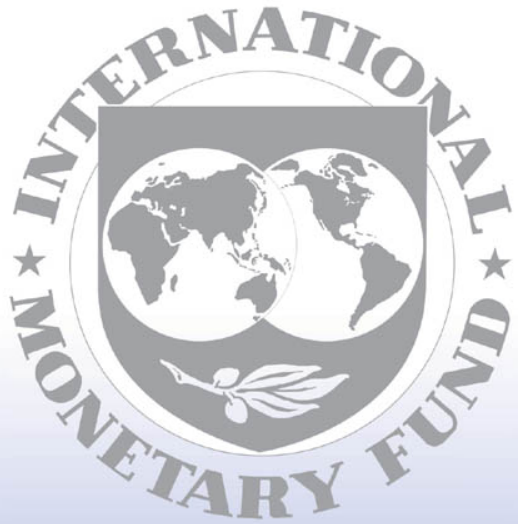

Staff

Country

Reports 


\section{Guyana: Recent Economic Developments}

This Recent Economic Developments report on Guyana was prepared by a staff team of the International Monetary Fund as background documentation for the periodic consultation with this member country. As such, the views expressed in this document are those of the staff team and do not necessarily reflect the views of the Government of Guyana or the Executive Board of the IMF.

Copies of this report are available to the public from

International Monetary Fund - Publication Services

700 19th Street, N.W. • Washington, D.C. 20431

Telephone: (202) 623-7430 - Telefax: (202) 623-7201

Telex (RCA): 248331 IMF UR

E-mail: publications@imf.org

Internet: http://www.imf.org

Price: $\$ 15.00$ a copy

\section{International Monetary Fund \\ Washington, D.C.}




\section{INTERNATIONAL MONETARY FUND}

\section{GUYANA}

\section{Recent Economic Developments}

Prepared by a staff team consisting of Gopal Yadav (Head), Shehadah Hussein, David Loevinger, and Mariana Torres (all WHD) and Guorong Jiang (PDR) Approved by the Western Hemisphere Department

April 28, 1999

Basic Data 3

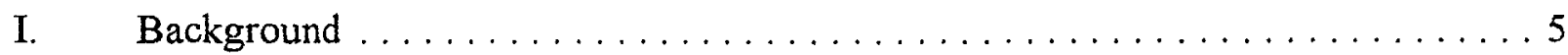

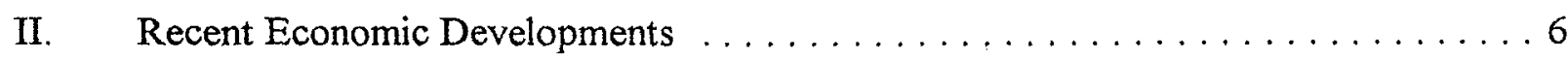

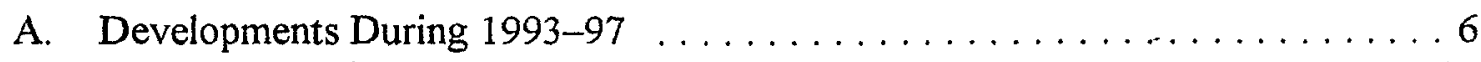

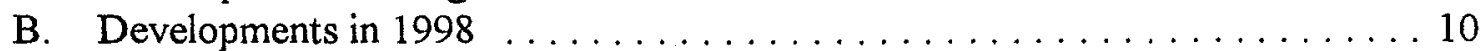

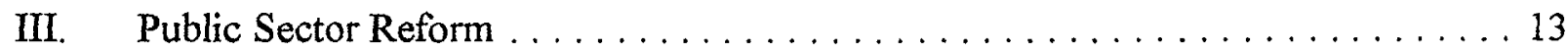

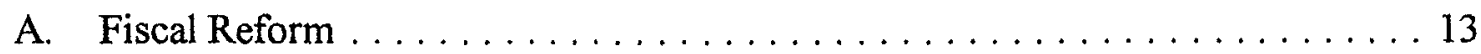

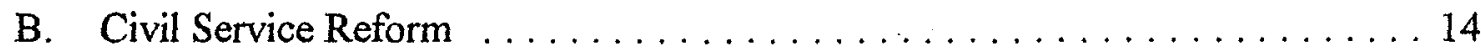

IV. Financial Sector and Business Environment Reforms ............. 16

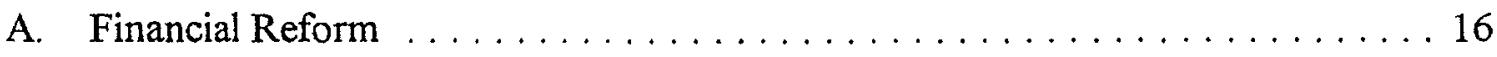

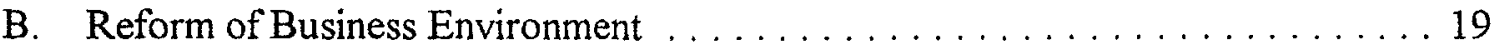

V. External Sector Reform .......................... 20

$\underline{\text { Boxes }}$

1. Selected Financial Reform Measures . . . . . . . . . . . . . . . . . . . . . 17

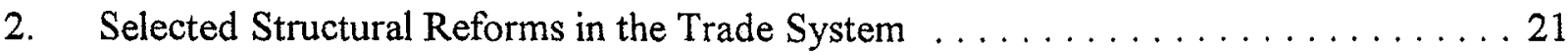

3. Selected Structural Reforms in the Exchange System $\ldots \ldots \ldots \ldots \ldots \ldots 22$

CInternational Monetary Fund. Not for Redistribution 
$\underline{\text { Tables }}$

1. Value Added by Sector . . . . . . . . . . . . . . . . . . . . . 33

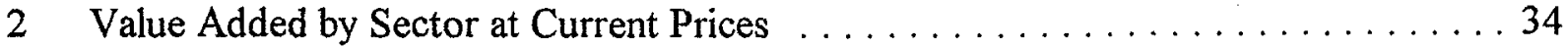

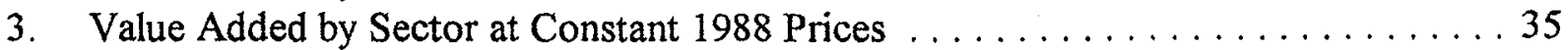

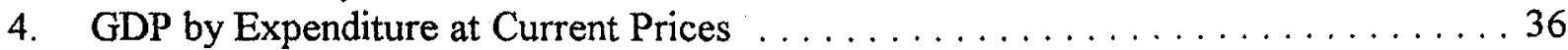

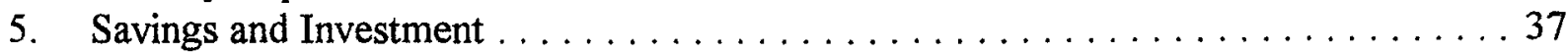

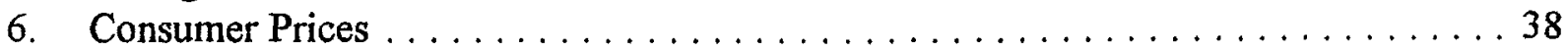

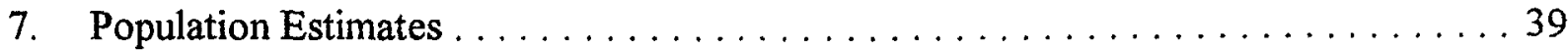

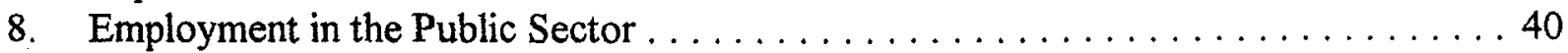

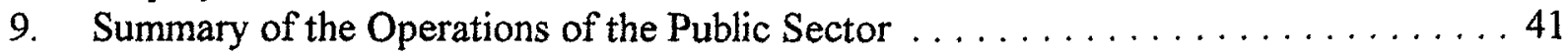

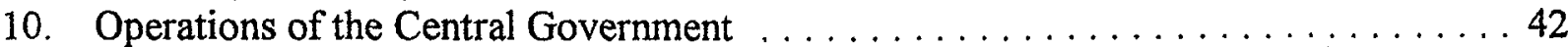

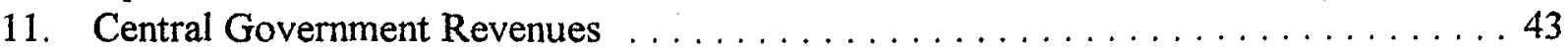

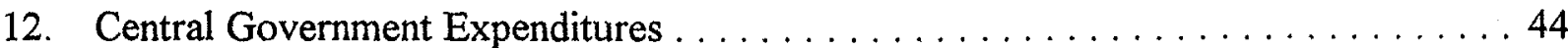

13. Summary of the Operations of the Public Enterprises $\ldots \ldots \ldots \ldots \ldots \ldots \ldots 45$

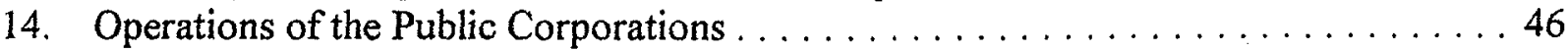

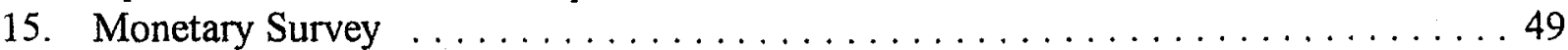

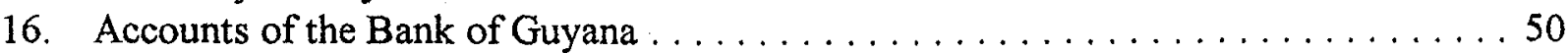

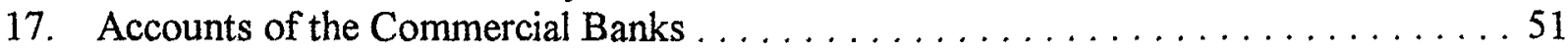

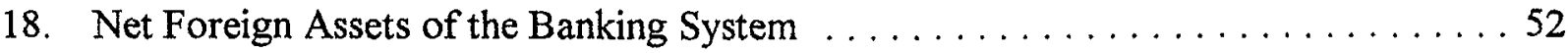

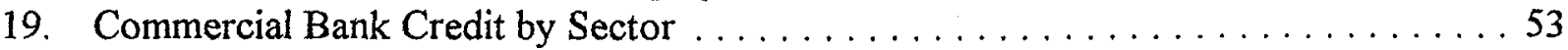

20. Liabilities of the Banking System to the Private Sector $\ldots \ldots \ldots \ldots \ldots \ldots \ldots 54$

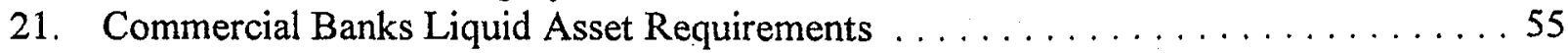

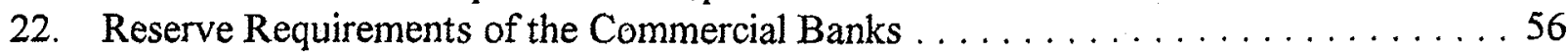

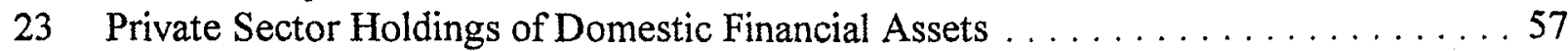

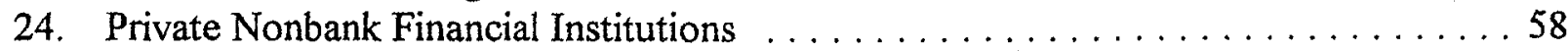

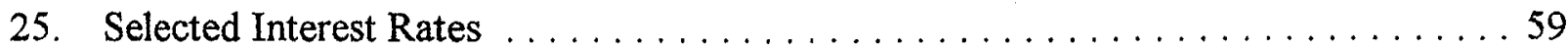

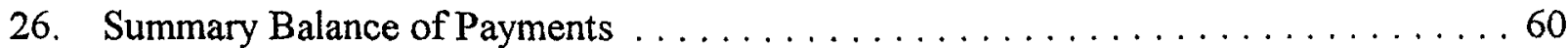

27. Value, Price, and Volume Indices for Exports and Imports $\ldots \ldots \ldots \ldots \ldots 61$

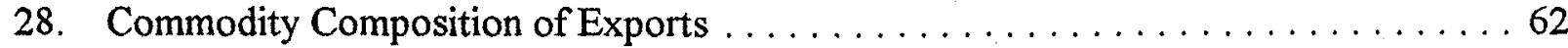

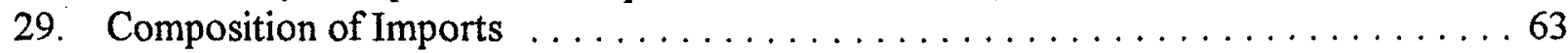

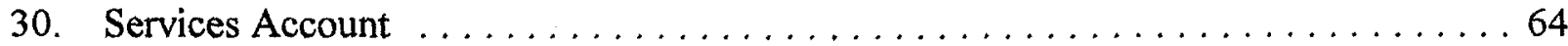

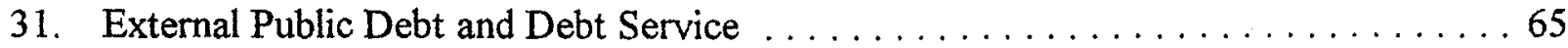

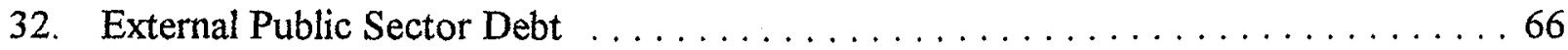

33. Effective Exchange Rates and Related Series $\ldots \ldots \ldots \ldots \ldots \ldots \ldots \ldots 67$

$\underline{\text { Figure }}$

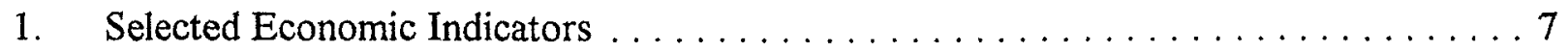

Appendices

I. Strengthening and Reorganization of the Bank of Guyana . . . . . . . . . 23

II. Reform of the Insurance and Securities Trading Industries $\ldots \ldots \ldots \ldots \ldots 26$

III. Summary of the Tax System as of December $31,1998 \ldots \ldots \ldots \ldots \ldots \ldots . \ldots 30$ 


\section{Guyana: Basic Data}

\section{Social and Demographic Indicators}

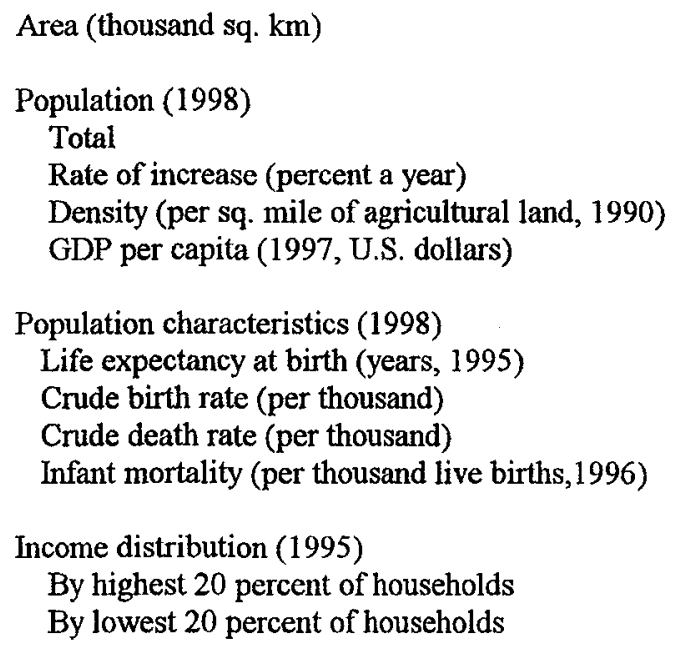

215
773,439
-0.2
113.5
932

65
27
6.8
24.2

52
6

Nutrition (1989)

Calorie intake (percent $\quad 86.6$ of requirement)

Protein intake (per capita $\quad 59$ grams a day)

Health (1998)

Population per physician $\quad 2,326$

Population per hospital $\quad 236$ bed

Access to safe water (percent of population, 1995) 83

Urban 100

Rural 75

II. Economic Indicators, 1993-98

Education (percent, 1993)

Secondary education enrollment rate

(In annual percent changes)

\section{National accounts and prices}

GDP at constant 1988 market prices Agriculture, forestry and fishing Mining and quarrying

Manufacturing

Construction

Services

Consumer price index (end of period)

Gross investment

Private investment

Public investment

Private consumption

Public consumption

Gross national saving

$\begin{array}{rr}8.2 & 8.5 \\ 5.9 & 12.2 \\ 49 & 6.6 \\ 3.3 & 5.8 \\ 3.5 & 20.0 \\ 3.4 & 5.6\end{array}$

... 16.1

8.1

7.9
7.4
15.2
5.7
14.0
6.1

6.2

4.0

15.0

2.5

13.1

5.3

4.5

4.2

(In percent of GDP)

$\begin{array}{rr}41.5 & 27.2 \\ 22.1 & 15.6 \\ 19.4 & 11.6 \\ 62.7 & 70.8 \\ 15.6 & 14.9 \\ 12.8 & 8.7\end{array}$

31.8

15.5

16.3

64.3

14.9

13.9
30.3

12.3

18.1

62.3

17.1

16.2
$-1.5$

$-5.1$

2.7

$-8.9$

4.8

0.7

4.7

(In millions of Guyana dollars)

\section{Public sector finances}

Revenue 1/

Noninterest expenditure 2/

Current primary balance (deficit -)

Overall balance before grants (deficit -)

Overall balance after grants (deficit -)

$\begin{array}{rr}17,248 & 23,582 \\ 12,009 & 11,588 \\ 5,239 & 11,994 \\ -12,146 & -4,276 \\ -9,438 & -799\end{array}$

(In percent of GDP)

Memorandum items:

Current primary balance

Overall balance before grants

Overall balance after grants

$\begin{array}{rrr}9.2 & 16.0 & 22.5 \\ -21.1 & -5.7 & -4.0 \\ -16.4 & -1.1 & -2.1\end{array}$
8 
Guyana: Basic Data (Concluded)

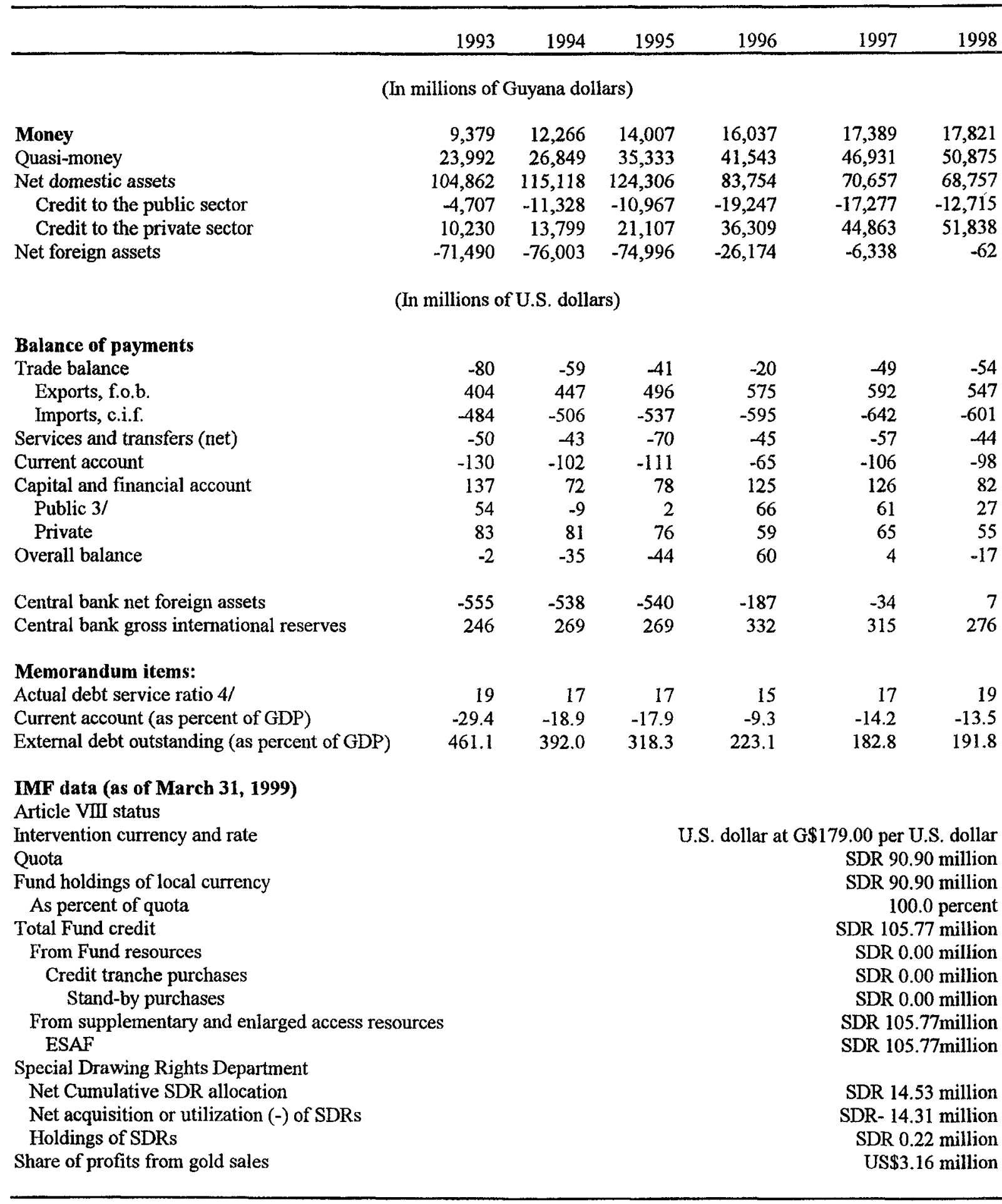

Sources: Guyanese authorities; World Bank; and Fund staff estimates.

1/ Excluding grants.

2/ For central government.

3/ Includes the effect of the 1996 Paris Club stock-of-debt operation on future principal maturities.

4/ External debt service as percent of exports of goods and nonfactor services. 


\section{BACKGROUND}

1. Guyana, an open and predominantly agricultural economy with considerable natural resources, had virtually a state-run economic system for over two decades following its independence in 1966. Under this system, major productive sectors (sugar, rice, bauxite, and gold) and financial institutions were brought under government control, prices were extensively controlled, foreign exchange was rationed, and government-owned consumer and marketing agencies were established. As a result, private sector growth languished, a parallel economy emerged, government administration became overburdened, and the public finances deteriorated.

2. Following sluggish growth during the 1960s and 1970s, the economy suffered from a steady decline in output and large macroeconomic imbalances during the 1980s. Real GDP fell at an average rate of 3 percent per annum during the 1980 s. Inadequate policy responses to a sharp deterioration in Guyana's terms of trade and weak external demand for its major exports (bauxite, rice, and sugar) led to lower production, large fiscal deficits, high inflation, depletion of external reserves, and rise in external indebtedness. By 1988 external payments arrears (mainly on debt service) had accumulated to about US\$500 million or 315 percent of GDP.

\section{In mid-1988 the government adopted a medium-term Economic Recovery} Program (ERP), with the assistance of the Fund and other donors, which aimed at fundamentally shifting the economy toward a market-oriented system. In mid-1990, Guyana cleared its overdue obligations to the Fund and negotiated a one-year Stand-By Arrangement and the first three-year arrangement under the Enhanced Structural Adjustment Facility (ESAF). During 1989-91 the government eliminated virtually all price controls (except for sugar and utilities); adjusted public sector tariffs closer to cost recovery levels; abolished import prohibitions and simplified the tariff structure in line with the CARICOM common external tariff (CET); unified the exchange rates; and introduced treasury bill auctions which formed the basis for market-determined interest rates. The government sold some 14 public enterprises, placed the state-owned sugar and bauxite companies under private management contracts and transferred the rice sector to private ownership. In addition, the efficiency of the public sector was substantially enhanced through broadening the tax base, curbing current expenditure, reducing current transfers to public enterprises, and rationalizing public administration with a reduction in the number of ministries from 18 to 11 .

\section{By 1991 economic performance had turned around in response to the shift in} economic policies and the improved incentive framework. Following sizable reductions in 1989-90, real GDP grew by about 7 percent a year in 1991 and 1992, mainly due to a recovery of export-related production (particularly sugar and rice) and new foreign investments in the bauxite, gold, and forestry sectors. By 1992 inflation had declined markedly (to 28 percent from about 90 percent in 1989); the fiscal and external deficits were reduced substantially; and private and official capital inflows had risen significantly. Section II below 
reviews economic developments since 1993. Structural reforms relating to the public sector, financial system, and external sector, are detailed in Sections III-V. Appendices I-III cover the reorganization of the central bank, the new legislations for the insurance and securities sectors and the current tax system.

\section{RECENT ECONOMIC DEVELOPMENTS}

\section{A. Developments During 1993-97}

\section{Assisted by adjustment programs supported by the Fund and World Bank,} Guyana's economy continued to grow strongly in the period 1993-97 (Figure 1). Real GDP grew by an average of 7 percent a year during the period with a strong growth in agriculture (particularly rice and forestry), mining (bauxite and gold), construction, transport, and telecommunications (Tables 1-4). Structural reforms, with emphasis on private sector ownership and management, helped increase the production of rice and sugar (despite the negative or low growth of both sugar crops in 1997 due to the El Niño-related adverse weather). Increased confidence in the economy boosted investment (particularly foreign investment) in the bauxite, gold and forestry industries. Light manufacturing (e.g., clothing and processed food and seafood) also registered growth. Inflation declined from 100 percent in 1991 to an average of 10 percent a year in 1993-97 (4 percent in 1997), supported by generally restrained monetary and fiscal policies, structural reforms, and a relatively stable exchange rate (Table 6).

6. National savings increased to 16 percent of GDP in 1997 (Table 5). Public sector dissavings of 1.7 percent of GDP in 1993 turned to a saving of 9.4 percent of GDP by 1997, as tax collections improved, and current public expenditure was restrained. Private savings relative to GDP also increased in the period 1994-97 as inflation declined, the exchange rate stabilized and real interest rates turned positive.

7. Public finances improved substantially during the period 1993-96. The overall deficit of the public sector fell from 21 percent of GDP in 1993 to 3 percent of GDP in 1996, reflecting substantial improvements in the finances of both central government and public enterprises (Tables 9-14). Given the relatively high ratio of tax revenues to GDP, improvements in the central government finances originated more from curbing expenditures than from increasing revenues. Tax revenue declined from 351/2 percent of GDP in 1993 to 32 percent in 1996 despite the measures taken to strengthen tax administration and reform the tax system (mainly through the simplification of the tax system, increasing indirect taxes, and alleviating the tax burden on individuals and corporations). However, the decline in revenue was more than offset by cuts in central government current expenditure (from $31 \frac{1}{2}$ percent of GDP in 1993 to 24 percent of GDP in 1996) - mainly reductions in transfers to the public and private sectors, decline in interest payments due to debt relief, and the containment of wages. However, central government capital expenditure increased (by 2 percent of GDP between 
Figure 1. Guyana

\section{Selected Economic Indicators, 1993-98}
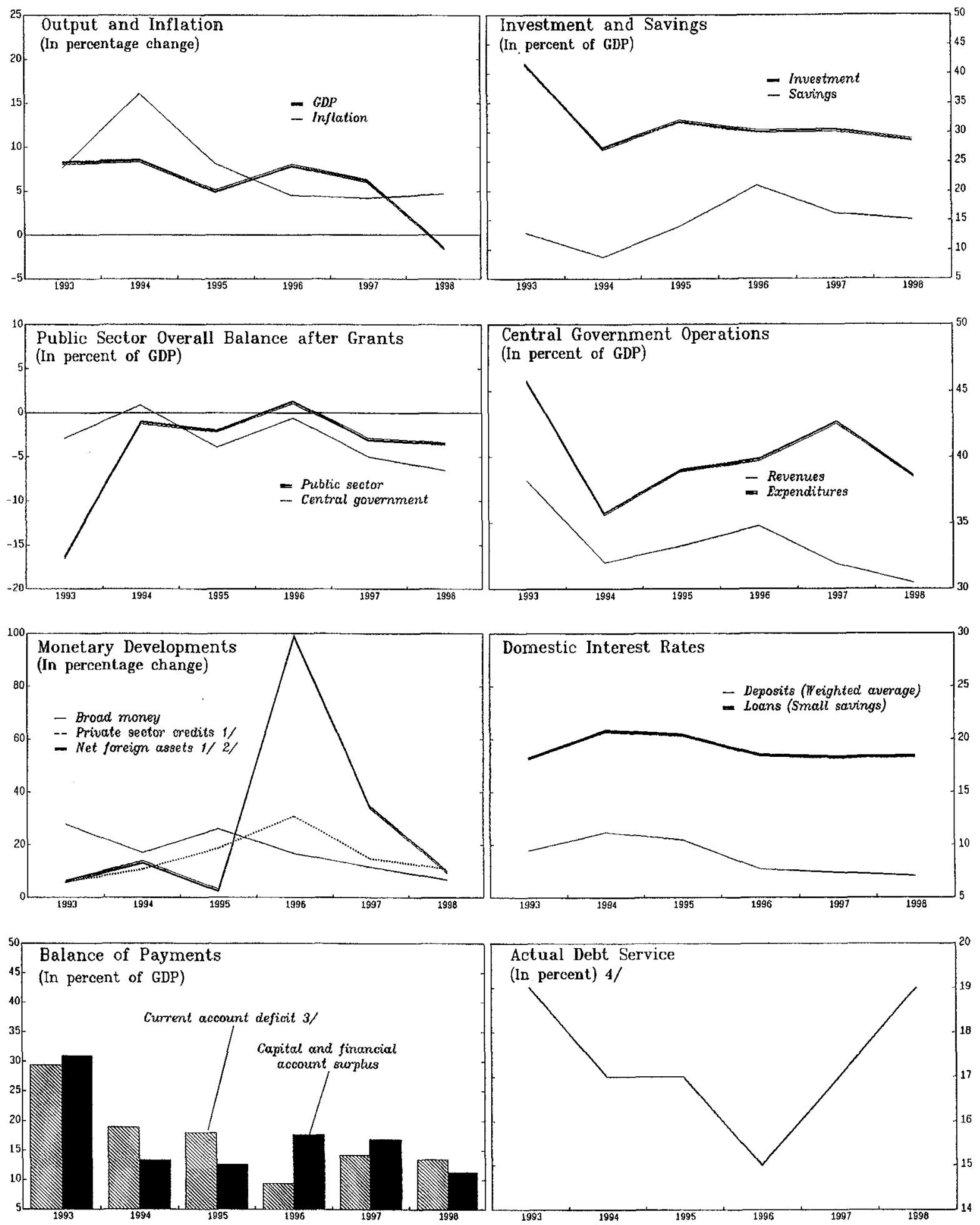

Sources: Data provided by the Guyanese authorities; and Fund staff estimates and projections.

1/ Contribution to liquidity growth.

2) 1996 projection includes the effect of the debt relief provided in May.

$3 /$ Excluding official transfers.

4/ In percent of exports of goods and nonfactor services. 
1993 and 1996) and focused on infrastructure (urban and rural roads, drainage, and irrigation) and social sectors (especially education and health facilities). The overall balance of the public enterprises improved from a deficit of 5.2 percent of GDP in 1993 to a surplus of 2.7 percent of GDP in 1996, mainly due to divestment, liquidation of unviable entities, and engagement of private management.

8. However, the fiscal performance faltered in 1997 , reflecting the elections-related economic disruption in the last two months of the year, expenditure overruns by two large public enterprises, and the adverse effects of the $E l$ Niño-generated drought. The overall public sector deficit before grants rose by $5 \frac{1}{2}$ percentage points of GDP to $81 / 2$ percent of GDP in 1997, mainly due to a weakening of the finances of the central government. The overall surplus of the public enterprises also fell by more than 1 percentage point of GDP, reflecting unanticipated outlays by GUYSUCO and Guyana Airways.

9. The growth of broad money decelerated from 28 percent in 1993 to $11 \frac{1}{2}$ percent in 1997, and the income velocity of money declined due to remonetization (Tables 15-18). During this period, the net domestic assets of the banking system fell at an average annual rate of 8 percent while the net foreign assets of the banking system increased sharply (mainly as a result of the Paris Club stock-of-debt reduction operation in 1996, and the transfer of foreign debt liability from the Bank of Guyana to the central government in 1997). The public sector increased its deposits at the Bank of Guyana, notwithstanding a reduction in 1997 reflecting the deterioration in the public finances. Growth in credit to private sector, while decelerating, was strong (averaging 37 percent per annum). The relative shares of bank credit to agriculture and service sectors increased in 1997 relative to 1993 (Table 19). In the banking system's liabilities to the private sector, there was a shift in favor of the interest-earning assets such as time and savings deposits compared to currency in circulation and demand deposits (Table 20). The ratio of actual to required liquid assets of commercial banks declined from 2.9 in 1993 to 1.7 in 1997 indicating increased preference for longer term placements, while the ratio of actual to required reserves increased somewhat (from 1.1 to 1.3) over the same period, indicating banks' continued comfortable liquidity position (Tables 21 and 22).

10. At end-1997, 75 percent of the private sector domestic financial assets were held in claims on the banking system and 23 percent with nonbank financial institutions (the Building Society, insurance and trust companies, and pension schemes). Nonbank financial institutions' claims on the private sector and other financial institutions increased substantially over 1993-97, partly at the expense of claims on the central government (Table 23-24).

\section{The treasury bill rate decreased from 15.4 percent in 1993 to 8.2 percent in 1997} as a result of the decline in inflation and the reduction in government borrowing (Table 25). Reflecting partly the high administrative costs and nonperfoming loans, the spread between the lending and deposit rates widened from 8 percentage points at end-1993 to about $101 / 2$ percentage points at end-1997. During this period the banking system reform progressed with the expansion of the supervisory role of the Bank of Guyana and the transfer of foreign 
liabilities from its books to the central government, the merger of two government-owned financial institutions (the Guyana National Commercial Bank and the Guyana Agricultural and Industrial Bank), the sale of the government's share in another bank (the National Bank of Industry and Commerce), and the restructuring of the only remaining government bank (the Guyana National Co-operative Bank).

12. The external position strengthened substantially during 1993-96. The current account deficit narrowed from 291/2 percent of GDP in 1993 to 91/2 percent of GDP in 1996 while gross official international reserves were at about five months of imports of goods and nonfactor services (Tables 26-32). The reduction in the current account deficit reflected increased exports (particularly sugar, rice, and nontraditional exports) and an improvement in the services account due to lower interest payments resulting from the debt relief. In the capital and financial account, the surplus fell slightly between 1993 and 1996 largely because of a slowdown of direct investment following the completion of major private projects in the timber and gold sectors. The large capital account surplus in 1996 reflected the effect of the 1996 Paris Club debt-stock operation under which Guyana received a debt forgiveness equivalent to around US\$524 million.

\section{In 1997 the balance of payments weakened and the Guyana dollar depreciated.} The external current account deficit rose to 14 percent of GDP from $91 / 2$ percent of GDP in 1996 due to the adverse effects of El Niño and a sharp decline in export prices. Value of imports rose by 8 percent partly on account of an acceleration in retooling (mainly in the manufacturing sector). Net capital inflows remained unchanged, with the increase in private capital inflows being offset by a smaller net official inflows (including transfers). Reflecting these developments, the overall balance of payments surplus fell from US\$60 million in 1996 to US\$4 million in 1997, and gross international reserves also declined although remaining at about $4 \frac{1}{2}$ months of imports of goods and nonfactor services. The weakening of the external position led to a depreciation of the Guyana dollar in terms of the U.S. dollar but in real terms the Guyana dollar appreciated by $81 / 2$ percent.

\section{Guyana's external public debt (including to the Fund) declined from about 461 percent of GDP (about US\$2 billion) at end-1993 to 183 percent of GDP} (US\$1.4 billion) at end-1997 (Table 32). The decline reflected mainly the effect of the stock-of-debt reduction (on Naples terms) in May 1996 from the Paris Club creditors (including Trinidad and Tobago). Debt to multilateral institutions increased steadily, constituting about 70 percent of the total debt at end-1997, while obligations to bilateral creditors continued to decline. Both the scheduled and actual debt service relative to exports of goods and nonfactor services declined during the period, with the latter falling from 19 percent in 1993 to 17 percent in 1997 (including the carryover of some interest payments from 1996 upon conclusion of bilateral agreements under the Paris Club stock-of-debt operations into 1997). 


\section{B. Developments in 1998}

\section{In 1998 real GDP declined by $1 \frac{1 / 2}{2}$ percent reflecting the lingering effect of the} El Niño-induced drought and forest fires, weaker demand and prices of Guyana's major exports, and continued civil disturbances through mid 1998. Output of sugar, rice, timber, gold, and many manufactured products declined compared with 1997. Retail sales also declined significantly, as many businesses were shut down during the periods of civil unrest. Consumer prices rose by $4 \frac{1}{2}$ percent, with increases in telephone charges and food prices being offset partly by lower oil prices.

\section{The overall public sector deficit before grants was reduced from $81 / 2$ percent of} GDP in 1997 to 5 percent of GDP in 1998 (Table 9). However, the overall public sector deficit after grants increased by $1 / 2$ percentage point of GDP to $3 \frac{1}{2}$ percent of GDP. The deficit was financed by net external loans and borrowing from the domestic banking system in amounts that more than covered the deficit, thereby allowing the public sector to reduce its other domestic debt and to recapitalize the Bank of Guyana.

17. The overall deficit of the central government (before grants) fell by $2 \frac{1}{2}$ percentage points of GDP to 8 percent of GDP in 1998 (Table 10). The improvement resulted from a reduction in interest obligations and a decline in capital spending, which overcompensated for the decline in revenue and a rise in the wage bill. The increase of $1 / 2$ percentage point of GDP in the wage bill resulted mainly from salary increases (averaging 19 percent), which were partly offset by reduction in employment. ${ }^{1}$ No new taxes were imposed in 1998 . However, the customs valuation exchange rate was adjusted (from G\$134 per US dollar to G\$144 per U.S. dollar), and certain fees and charges were increased (licenses fees for vehicles, airport departure fees, inter alia) to cost recovery levels.

\section{The operating surplus of the rest of the public sector increased by $1 / 2$ percentage} point of GDP in 1998, reflecting mainly a strengthening of the financial position of the National Insurance Scheme (NIS). The operating balance of the NIS improved by $1 / 2$ percentage point of GDP as a result of the sale of its shares of the NBIC, which was only partially offset by higher benefits payments and lower interest income. ${ }^{2}$ The operating surplus of the state enterprises remained constant at around 2 percent of GDP. The operating surplus of the sugar company (which accounts for almost half of public enterprises' total operating revenue) stabilized (at $2 \frac{1}{2}$ percent of GDP) as the impact of a $7 \frac{1}{2}$ percent reduction in sugar production was offset by the depreciation of the Guyana dollar. One bauxite company

${ }^{1}$ Civil service wage negotiations for 1998 were concluded in July 1998, which included $91 / 2$ percent increase from January 1, 1998 and additional increases ranging from $4 \frac{1}{2}$ percent (for higher grades) to $201 / 2$ percent (for lower grades) effective July 1, 1998.

${ }^{2}$ In 1998 the NIS decided to begin to hold government papers of longer-term maturities, which shifted the receipt of interest on their papers from 1998 to 1999. 
(BERMINE) improved its operating balance due to reduced freight costs and the depreciation of the Guyana dollar. The other bauxite company (LINMINE) incurred a deficit similar to that registered in 1997 as its production capacity was curtailed, reflecting technical and marketing problems. The state airline's operating balance continued to deteriorate in 1998 (with a deficit of 0.5 percent of GDP) due to technical difficulties (including the grounding of a leased aircraft several times during the year). The other small enterprises realized an operating surplus before taxes similar to that registered in 1997.

\section{Broad money and private sector credit slowed down markedly in 1998, but net} credit to the public sector accelerated. Growth of broad money slowed from $11 \frac{1}{2}$ percent in 1997 to 7 percent in 1998, while the growth of currency also slowed from $12 \frac{1}{2}$ percent to $11 / 2$ percent. Credit to the private sector increased by $151 / 2$ percent compared to $231 / 2$ percent in 1997. Net credit to the public sector increased by $261 / 2$ percent (compared to 10 percent in 1997 ) as the central government drew down its deposits while the rest of the public sector improved its net asset position at the banking system. The gross international reserves of the Bank of Guayana fell from US\$315 million at end-1997 to US\$276 million at end-1998, but the net foreign assets of the banking system improved reflecting the transfer of certain external debt of the Bank of Guyana to the central government. Deposit rates declined from $81 / 2$ percent at end-1997 to 8.2 percent at end- 1998 while the weighted average lending rate remained virtually unchanged at 18.4 percent. The 91-day treasury bill rate rose by 60 basis points to 8.8 percent at end-1998.

20. The external current account deficit (excluding official transfers) narrowed slightly from 14 percent of GDP in 1997 to $13 \frac{1}{2} / 2$ percent of GDP in 1998 as a decline in export proceeds was virtually offset by lower import payments and the services account improved due to lower interest payments (Table 26). The external terms of trade worsened by 1 percent, as a decline in export prices was only partially offset by lower oil import prices (Table 27).

\section{Export receipts fell by $71 / 2$ percent in 1998 , as both prices and volume declined} (Table 28). Sugar export suffered from lower production, with export volume declining by $71 / 2$ percent due to the effect of El Niño. The volume of rice exports contracted by over 12 percent as production of the first crop was adversely affected by the drought and export of the second crop was delayed. The gold price continued its slide, with export earnings declining by over 9 percent. Timber export was substantially lower due to the Asian Crisis which depressed demand and price. The volume of plywood exports recovered by 18 percent as labor relations normalized and technical difficulties were resolved. However, this was offset by a 30 percent decline in the export price of plywood. Nontraditional exports of garments, fish, and shrimp registered strong growth, though from a low base.

22. Imports were lower by about 6 percent compared to 1997 , as a result of depressed economic activities and lower oil prices (Table 29). Imports of consumption goods increased by $6 \frac{1}{2}$ percent, as large increases in the first quarter reflected carryover from last year due to political unrest, which delayed the imports for the holiday season at end- 1997 . 
Imports of intermediate goods experienced a slight decline, with sharp contractions in capital goods imports resulting from lower investment. In the services account, interest payments were lower mainly due to debt relief and the appreciation of the U.S. dollar against major currencies, which was partly offset by the lower tourist earnings due to political uncertainty.

\section{There was a sharp decline in net official capital inflows, as project loans and} grants declined due to shortage of locally produced construction materials (bricks, stones, etc.), difficulties in meeting conditionalities associated with projects, and the limited project implementation capacity of local contractors. Net private capital inflows (including errors and omissions) increased marginally as the decline in direct investment (resulting from uncertainties in the domestic and external financial markets) was more than offset by lower other private capital outflows. Reflecting these developments, the gross international reserves declined from US\$315 million at end-1997 to US\$276 million at end-1998.

\section{The Guyana dollar depreciated from G\$144 per U.S. dollar at end-1997 to G\$165} per U.S. dollar at end-1998 despite central bank interventions. In real effective terms, the Guyana dollar depreciated by around 9 percent during 1998, thereby offsetting a large part of the appreciation of the preceding three years (Table 33).

25. The authorities continued to make efforts to normalize relations with the creditors and continued to pursue a prudent external debt management policy to maintain a high degree of concessionality in new external borrowing. In 1998 rescheduling agreement with the OPEC Fund to clear arrears was implemented and negotiation with bondholders continued. The stock of external debt remained at about US\$1.4 billion, or about 192 percent of GDP. Actual debt service ratio rose to about 19 percent of exports of goods and services, reflecting the payments of arrears. The fiscal burden of debt remained heavy, with actual government debt service payments in 1998 amounting to almost 40 percent of the central government revenue.

\section{The authorities have been improving the debt management capacity, with} technical and financial support from the Debt Relief International (a donor funded nongovernmental organization) and the UK Department for International Development (DFID). Since February 1999, a reorganization plan is being implemented for the Debt Management division in the ministry of finance that distinguish clearly between recording and analytical functions. ${ }^{3}$ A comprehensive training program covering both recording and analytical aspects of the debt management and computerization for the staff has been agreed with the Debt Relief International and consultants have been recruited.

\footnotetext{
${ }^{3}$ Three additional technical persons were hired in early 1999 and additional computers and office equipment were put in place by March 1999. The training started in February and will last for about a year.
} 


\section{Public Sector Reform}

\section{A. Fiscal Reform}

27. Until 1989 the tax system had suffered from several deficiencies, including a narrow income tax base with six tax brackets and high marginal rates (with a maximum of 55 percent). State corporations were exempted from the payment of consumption taxes and import duties, and their payments of dividends and income tax to the government were not seriously enforced. In addition, there were many specific taxes and corporations paid taxes annually on the basis of the previous years' profits. Also, the overall tax administration was weak.

28. Efforts to correct these deficiencies started in 1989 with the conversion of all specific consumption taxes to ad valorem bases, the ending of exemptions of state corporations from consumption taxes and import duties, and a reduction in the number of consumption tax rates from fourteen to three. In addition to these measures, the government entered into an agreement with the UNDP to provide training and resources to improve tax administration.

29. In 1991 a comprehensive tax reform program was introduced. An important action was the increase in the personal income tax threshold from $\mathrm{G} \$ 10,000$ to $\mathrm{G} \$ 48,000$. The concept of taxable income was expanded to include income (cash and in kind) from all sources, and all previous allowances and deductions were withdrawn. The six income tax brackets were replaced with three, and the highest marginal rate was reduced to 40 percent. Other important measures included a withholding tax on gross interest earned by individuals and companies, the introduction of the rice levy, ${ }^{4}$ and an amnesty for taxpayers in arrears for the period 1984-90. The corporate tax rate was reduced from 55 percent in 1992 to 35 percent in 1995 and the income tax threshold rose continuously from G\$48,000 in 1991 to G $\$ 216,000$ by 1998 .

30. Also, since 1991 efforts have been made to improve tax administration and enforcement. These efforts included more frequent tax audits of individuals and corporations, and revisions to the registry of manufacturers in 1991 and the registry of landlords in 1993. In addition, the tax base was widened by targeting self-employed with the introduction of a minimum tax on gross sales and some increases in licenses and fees. In 1994 the authorities abolished the system of tax holidays while allowing those in existence to remain in place until their expiration dates. Equally important were efforts to remove corrupt officials including the introduction of several regional anti-smuggling squads.

31. In 1995 a comprehensive approach was taken with respect to reforms in the Customs and Inland Revenue departments. The new initiative sought to remove these

\footnotetext{
${ }^{4}$ Set at the level of cost recovery to the Rice Board.
} 
divisions from the civil service and create a new autonomous Revenue Authority to be run by its own board. In July 1996 the National Assembly approved the Revenue Authority Act, which combined the mandates of the two departments and placed them under a commissioner general who would report to a governing board. The main objectives of establishing the Revenue Authority are to: (a) improve the efficiency of both departments by eliminating the duplication of common services and functions, such as management and legal services, human resource management, and internal audit; (b) improve collection, compliance and enforcement activities by strengthening existing units; and (c) attract and retain expertise in the tax and customs departments and operate more closely in line with the needs of the business community by relieving the administration from the government's constraints on hiring, salary, and operations.

32. Consultants have been recruited to develop organizational and legal structure, job descriptions, and computer systems in the new Revenue Authority. However, a court decision enjoined government from establishing the Authority as some staff of Customs and Excise departments had instituted a court action against the government for elimination of their positions in the Revenue Authority. On June 4, 1998, the government filed a motion to have the injunction lifted, and it is expected that the Revenue Authority would become operational as soon as the court injunction is lifted.

\section{B. Civil Service Reform}

33. In order to improve the efficiency of the civil service and the ability of the government to attract and retain skilled personnel, the government has been working since 1993 to reform the civil service with the assistance of the World Bank, IDB, and bilateral donors (particularly the United Kingdom). However, progress has been slow partly due to the fact that new organizational structures and staff responsibilities have not been matched by simultaneous improvements in compensation and conditions of service due to the budgetary constraints. Employment in the public sector has been declining, resulting in a significant understaffing of professional, managerial, and technical positions.

\section{The government currently pursues a broader civil service reform strategy, which} has two essential components: vertical reforms in individual public institutions to strengthen organization, management, and human resources; and horizontal reforms across institutional boundaries to improve the environment in which public sector entities function. Under vertical reforms, the reorganization of the ministry of finance was completed in 1998. The reorganization focused on the organizational weaknesses such as overcentralization, ineffective management and decision-making processes, unclear lines of authority, and inadequate staff development policies. To deal with these weaknesses, several actions have been taken, including preparation of a staff handbook to define the human resources policy framework and guidelines; and assessment of leadership requirements, training and development needs, scope of work rules and responsibilities, staffing needs and job descriptions for all positions within the new organizational structure. In addition, major 
renovation and rehabilitation took place to prepare the physical facilities for upgrading the management information system as well as to prepare departmental offices for hiring qualified personnel. Vertical reforms are also proposed for the ministries of education and health under the HIPC Initiative in the social sector. The restructuring of the ministry of finance is being used as a prototype to restructure these ministries.

35. While these vertical restructuring efforts are being implemented, crucial and complementary horizontal reforms have been carried out simultaneously. In this context, the government is committed to reviewing and streamlining the public service rules. To this end, a committee of private sector, government, and public sector union officials began to review the public service rules in May 1998, and the review was completed in December 1998.

36. Recognizing that one of the main problems in attracting skilled workers was that real public sector wages had deteriorated significantly in the 1980s and early 1990 s, the government first introduced a new 14-band salary structure in 1993. Since 1994, the government has granted a series of wage increases intended to achieve the mediumterm goal of bringing public sector wages gradually to within 10 percent of the median for comparable jobs in the private sector. In addition to these across-the-board increases, the government provided supplements over base pay to key and critical positions, where the salary gaps are much larger. At the same time, to maintain a sound fiscal position, the government has been reducing the size of the civil service. ${ }^{5}$

\section{Despite these efforts, the government continues to experience difficulties in} attracting and retaining skilled personnel. Under the current ESAF arrangement, the government has renewed its efforts to overcome this problem. In 1998 the government commissioned two surveys to compare the pay scales in the public and private sectors. The surveys concluded that public sector pay remained lower than private sector pay for comparable positions. To address this, the government is working on a new remuneration structure for professional, technical, and managerial positions.

\footnotetext{
${ }^{5}$ Between 1991 and 1998 central government employment declined from 17,800 to 9,400 and total public sector employment (including state enterprises) decline from 65,700 to 36,300 (Table 8). However, this data does not include security forces, teachers, public health care workers, regional administrators, and staff in autonomous agencies.
} 


\section{FinANCIAL SECtor AND BUSINEsS ENVIRONMENT REFORMS}

\section{A. Financial Reforms}

38. The financial system consists of the Bank of Guyana, the country's central bank established in 1965; seven commercial banks (four domestic and three foreign-owned banks) with a network of 30 branches; ${ }^{6}$ a large number of credit unions including the New Building Society; ${ }^{7}$ six insurance companies; and five trust companies. All commercial banks and trust companies are governed by legislation under the Financial Institutions Act of 1995 and are supervised by the central bank. ${ }^{8}$ At end- 1998 about 74 percent of private domestic financial assets were held with the banking system, while the remainder was held with nonbanks (251/2 percent) and in government securities (see Table 23). Commercial banks invest about 28 percent of their net domestic assets in treasury bills, which are the central bank's principal monetary management instrument. Markets for long-term debt securities (e.g., debentures), interbank money and securities are still very shallow.

\section{Prior to reforms which started in 1988 , monetary policy was conducted mainly} through direct controls on credit and interest rates (the latter, through the rediscount rate fixed by the central bank and used by commercial banks to set their deposit and lending rates) and adjustment of the minimum liquid and reserve requirements. Open-market operations were precluded by the lack of an established financial market and by the substantial losses of the central bank (due mainly to its high foreign debt-service payments).

40. Financial reforms in Guyana were started in $\mathbf{1 9 8 8}$ and aimed at enhancing efficiency by increasing reliance on market forces, reducing controls on the financial system, strengthening the capacity to conduct monetary policy, and improving the effectiveness of policy responses to external shocks (Box 1). In 1988 interest rates and credit controls were removed, launching the move to a market-oriented economic system. By end-1989 interest rates had increased to about three-fold their pre-reform levels.

${ }^{6}$ Of these, only the Guyana National Co-operative Bank (formed by the merger of two stateowned banks in May 1995) is still state-owned. In October 1997, a 51 percent share of the National Bank of Industry and Commerce (NBIC), formerly owned by the government, was sold to the Republic Bank of Trinidad and Tobago.

${ }^{7}$ Because of weak performance, the Guyana Co-operative Mortgage Finance Bank (a specialized financial institution established in 1973 to provide home mortgage for low-income families) was closed at end-1998 and its loan portfolio was transferred to the Guyana Co-operative Financial Services.

${ }^{8}$ The New Building Society, the main mortgage-finance institution is governed by the Co-operative Financial Institutions Act (COFA), while the insurance companies are under the supervision of the Commissioner of Insurance. 


\section{Box 1. Guyana: Selected Financial Reform Measures}

April 1989

July 1989

June 1990

July 1990

April 1991

June 1991

March 1992

June 1994

December 1994

March 1995

May 1995

February 5, 1996

January 1, 1997

January 2, 1997

October 1997

July / September 1998

September 1998

November 1998

January 1999
Bank rate increased from 14 percent to 35 percent, and the treasury bill rate increased from 11.3 percent to 33.7 percent.

Liquid asset holdings of the commercial banks were frozen for a period of six months.

The rediscount rate for treasury bills was set at 1 percentage point above the treasury bill rate.

To strengthen the institutional framework for the conduct of monetary policy, a monetary policy unit was established in the central bank.

Two thirds of the conversion of excess liquidity of commercial banks into medium-term liabilities was completed with the remaining amount scheduled to be completed by endOctober 1991.

Competitive bidding for treasury bills was introduced.

Central bank implemented new mechanism for the determination of the bank rate, special deposit rates, and the rediscount rate where these rates were a function of the market-determined treasury bill yields.

The frequency of 91-day treasury bill auctions increased from monthly to a biweekly.

Special reserve deposits of banks were remunerated/eliminated.

The Financial Institutions Act (FIA) was passed and became operational in May 1995.

To ensure conformity with the FIA, amendments were made to the Cooperative Financial Institutions Act, the dealers in foreign currency (Licensing) Act, the Companies Act, and the Capital Issues (Control) Act.

Weekly auctions for 91 -day treasury bills commenced.

As part of the currency reform program, the public was asked to stop using the $\$ 1, \$ 5$, and $\$ 10$ notes.

In accordance with the FIA, the Bank of Guyana issued a provisional license to GNCB Trust Corporation to carry on depository financial business with authority to engage in trust business in Guyana.

Republic Bank of Trinidad and Tobago purchased the government-owned 51 percent share in NBIC.

Bank of Guyana revised the 1966 circulars on reserve and liquid assets requirements of all licensed financial institutions in line with international standards.

Bank of Guyana introduced the National Clearing House, which significantly reduced the time for processing interbank checks by commercial banks.

Parliament passed the revised Bank of Guyana Act for the reorganization and recapitalization of the Bank (Bank's capital raised from G\$6 million to G\$1 billion).

The Bank of Guyana reduced the reserve requirement ratios of licensed financial institutions from 16 to 14 percent on demand and time liabilities, respectively, to 12 percent on all liabilities. 
41. Monetary management was strengthened by improving the conduct of its treasury bill auctions, and interest rates policies. In mid-1991 the central bank introduced competitive bidding in its monthly 91-day treasury bill auctions (operated on behalf of the government); and since March 1992, administered rates such as the bank rate, special deposit rates, and the rediscount rate have been set in relation to the market-determined 91-day treasury bill rate. ${ }^{9}$ Also, to enhance competition in the treasury bill market, the central bank decreased the rate on special deposits (from $2 \frac{1}{2}$ to $31 / 2$ percentage points below the Bank rate) and increased the penalty for using the rediscount facility (from 2 to 3 percent). In April 1993 the central bank started to auction longer maturity treasury bills (182-day and 364-day), while the frequency of the 91-day treasury bill auctions was increased to a biweekly basis in January 1994, and to a weekly basis in February 1996. In January 1999 the central bank removed the collar on the treasury bill bids in the weekly auctions to allow interest rates to reflect market forces more quickly. ${ }^{10}$

42. Reserve and liquid asset requirements were also used to increase the effectiveness of monetary policy. In keeping with an increasingly restrained monetary stance and given banks' generally comfortable liquidity position, reserve requirements on demand, and saving and time deposits respectively were raised by 4-5 percentage points in April 1994. In July 1998 the scope of reserve requirements was enlarged to include all licensed nonbank depository institutions and the coverage was extended to include foreign currency deposits. However, reserve requirements were reduced from an average of 15 percent to 12 percent on all liabilities (demand, savings, and time deposits) in February 1999 mainly to reduce the cost of funds and, thereby, lending rates. Treasury bills were issued in higher volumes and with longer maturities to mop up the initial increase in liquidity due to the freed reserves. The liquid assets requirement has remained at 25 percent for demand deposits and 20 percent for time deposits since May 1991.

43. To enhance the efficiency and competitiveness of banks, financial reform also included the reduction of the government's share in the financial sector. Toward this end, the government agreed with IDA to bring down its share in financial entities to no more than 25 percent of the asset value of those entities at end-1993. The government achieved this goal with the sale of all its shares in the largest two commercial banks: the Guyana Bank for Trade and Industry in August 1994, and the National Bank for Industry and Commerce in October 1997.

${ }^{9}$ Special deposit rates applied to banks' excess reserves at the central bank and remained in effect until end-1994, after which excess reserves became nonremunerated.

10 This replaced the previous system which required that the deviation in yield in bids in a current tender be no more than two percentage points of the average yield in the previous tender. 
44. Strengthening and updating the regulatory and supervisory framework for financial institutions reinforced the monetary policy reforms and was effected through the enactment of the Financial Institutions Act (FIA) in May 1995. To ensure the safety and soundness of the financial system FIA required that all financial institutions be licensed by the central bank, and extended the central bank's surveillance responsibility to all deposit taking financial institutions; ${ }^{11}$ upgraded the capital adequacy requirement and asset risk classification to internationally accepted standards; and introduced other regulations to limit risk and concentration of ownership of financial institutions (e.g., limits on loans to single borrower and on investment in nonbank companies; and rules regarding insider trading, loan classification and provisioning, and minimum capital for setting up a bank).

\section{Institutional strengthening of the Bank of Guyana with a view to enhancing its} autonomy and capacity to conduct monetary policy formed another key element of financial sector reform (see Appendix I). Efforts to strengthen the Bank have culminated in the passage by parliament in November 1998 of the revised Bank of Guyana Act (1998). The revised act recapitalized the central bank by raising its authorized and paid-up capital to G\$1 billion from G\$6 million; allowed the transfer of further foreign debt liabilities from its books to the central government; prohibited the central bank from extending credit to the central government or public enterprises; authorized the central bank to issue and trade its own securities for the purposes of open market operations; and introduced organizational changes in the bank's board of directors.

\section{B. Reform of Business Environment}

46. In order to improve the business climate for private sector, legislation was passed in late 1998 to establish the regulatory frameworks for the insurance and securities trading and to reform the Deeds Registry. The Insurance and Securities Acts seek to strengthen the regulatory aspects of the two industries and improve the rules regarding medium- and longterm credit to local businesses and small investors (Appendix II). Reform of the Deeds Registry (including making it a semi-autonomous entity) will expedite the processing of land titles, allow for the use of a more diverse range of collaterals and thus enhance private sector access to capital. Reform of the land tenure policy will step up the conversion of lease-holds to free-holds, allow the extension of long-term leases beyond 25 years, and increase the sale of state lands. The government also has prepared legislation (to be tabled in parliament in 1999) on bankable property rights with a view to improving private sector access to bank credit.

11 These included all commercial banks and trust companies and other deposit-taking institutions; insurance companies remained under the supervision of the Commissioner of Insurance. 


\section{EXTERNAL SECTOR REFORM}

47. During the transformation from a public sector dominated economic system to a market based, private sector led economy, major progress has been made in external sector reforms, including the liberalization of foreign trade, the elimination of foreign exchange controls, and the opening up to foreign direct investment. Currently, Guyana does not maintain any restrictions on making payments and transfers for current international transactions. Its external trade system is virtually free of quantitative controls, except for restrictions on import of few items relating to health and security.

48. In the 1980s Guyana's trade system was overly restrictive, complex and riddled with prohibitions, licenses, and limited access to foreign exchange. Imports were subject to high tariffs, individual licensing by the ministry of trade, and allocation of available foreign exchange from the central bank. Exporters had to surrender most of their foreign exchange earnings to the central bank and some of the major exports (rice and gold) had to go through marketing boards.

49. From the late 1980s the trade system was gradually liberalized (Box 2). Licensing requirements for imports have been abolished, except for petroleum products ${ }^{12}$ and some 20 items affecting national security, health, public safety, and the environment. Foreign exchange surrender requirements were abolished in December 1996, and restrictions and marketing board arrangements on exports were removed except for licenses for exports of gold ${ }^{13}$ and wildlife, and quotas for the supply of some commodities to preferential markets.

\section{The import tariff has been reduced substantially since the government passed} legislation in February 1991 to apply the Common External Tariff (CET) to all imports from outside the CARICOM market. Current tariffs range from 5 percent to 25 percent, with a few exceptions: notably, passenger and private vehicles (with a 45 percent tariff), and alcoholic products, cigarettes, and other tobacco products (with a 100 percent tariff). In principle, intra-CARICOM trade is free of import duties. However, there exists a few exceptions to duty free trade from CARICOM, including alcohol, pharmaceuticals with high content of alcohol, perfumes, matches, and curry.

\footnotetext{
${ }^{12}$ The Government of Guyana does all importation of fuel to the country through GNEA, which does documentation and importation and sells to private distributors, GUYOIL (government owned) and government departments, all at the same price.

${ }^{13}$ Exports of gold required permits from the Guyana Gold Board. Licenses were granted to eight local dealers in May 1997 for one year experiment and has been extended by another year from April 30, 1998.
} 
Box 2. Guyana: Selected Structural Reforms in the Trade System, 1988-99

June 1988

August 1988

September 1988

October 1988

February 1991

October 1992

January 1994, September 1995

November 1997

April 1999
The import licensing requirements were abolished for goods intended for personal use that would not involve official foreign exchange.

Import prohibitions on a number of manufactured products were eliminated. Prohibitions were limited to certain food products and permissible imports were subject to individual licensing by the ministry of trade except for personal effects, gifts, and primary agricultural products from CARICOM countries.

Import licenses for no-foreign currency imports were granted automatically.

Import licensing requirements for goods originating and consigned from CARICOM countries were removed.

Legislation to bring Guyana in line with the Common External Tariff (CET) of the Caribbean Common Market (CCM) was approved. A Common External Tariff (CET) was applied to imports from outside CARICOM.

CARICOM member states agreed to a phased reduction in the CET rate structure from the existing rates of 0-45 percent to 5-20 percent by January 1, 1997 (which was later extended). For basic competing primary inputs and capital goods, the average rate was to fall from 30 percent to 10 percent.

Guyana implemented the first and second steps in the phased CET reduction, lowering its maximum tariff rate from 45 to 30 percent.

Guyana implemented the third step in the phased CET reduction, lowering its maximum tariff rate from 30 to 25 percent.

Guyana is expected to implement the fourth and final phase of the reduction by lowering its maximum tariff rate from 25 percent to 20 percent.

\section{The exchange rate is determined freely in the market, with the central bank} intervention limited to smoothing sharp movements in the exchange rate. The Bank of Guyana conducts certain transactions on the basis of the cambio exchange rate by averaging quotations of the three largest dealers. The present exchange rate arrangement developed from the successive efforts to reform the market: the unification of the official and cambio markets in February 1991, the abolishment of Exchange Control Act in December 1995, the reduction and eventual abolishment of foreign exchange surrender requirements in December 1996 (Box 3). 
Box 3. Guyana: Selected Structural Reforms in the Exchange System, 1987-96

February 1987

April 1989

March 1990

June 1990

February 1991

August 1993

December 1995

December 1996
A secondary foreign exchange window at commercial banks was established with the intention of operating at a market-related rate.

The Bank window rate and special rates for gold and diamonds were abolished and the official rate was devalued by about 70 percent, to G\$33.00 per US\$1.

The cambio market was established as a first step toward unification of the exchange rate system. The new system introduced two markets - the official and the cambio markets.

The Guyana dollar was further devalued from G\$33 per US\$1 to G\$45 per US\$1. This was effected to correct the wide and growing disparity between the parallel market rate (G\$55 to G\$60 per US\$1) and the official exchange rate (G\$33 per US\$1).

The Guyana dollar in the official market was again devalued from G\$45 to G\$101.75 per US\$1, the level prevailing in the cambio market on that date. The official rate was determined weekly based on the average free-market rates for the preceding week.

With a view of achieving closer integration of the official and cambio markets, the Bank of Guyana initiated a policy of foreign exchange transactions with the cambio market. Consistent with its target for gross international reserves, the bank was able to supply US\$21.9 million to that market.

The Exchange Control Act was abolished.

The foreign exchange surrender requirements for exporters were abolished. 


\section{Guyana: The Strengthening and Reorganization of the Bank of Guyana (BOG)}

1. Efforts to strengthen the functioning of the central bank (the Bank of Guyana) have proceeded in earnest over the last few years and have culminated in the passage by parliament at end-November 1998 of the revised Bank of Guyana Act (1998). These efforts have aimed at the modernization of the bank's structure and operations, enhancing its autonomy, and increasing its capacity to conduct monetary policy.

2. Key reforms prior to the passage of the revised BOG Act included the following:

(i) Strengthening the income and balance sheet positions of the bank by reducing foreign debt liabilities on its portfolio either through debt relief or by the transfer of foreign debt from its books to central government. Under the Paris Club debt-stock reduction operation for Guyana in May 1996, BOG's foreign liabilities were reduced by about US $\$ 287$ million. Also, in 1997 foreign liabilities of US\$145 million owed to Paris Club creditors were transferred from the BOG to central government. Largely because of these operations, BOG's net foreign asset position was substantially strengthened (from-US\$540 million at end-1995 to US\$14 million at end 1998), and the bank started to make profits since 1997 (amounting to G\$458 million in 1998).

(ii) The introduction of a reserve money programming framework in early 1998 to improve liquidity management in line with the foreign reserve and inflation objectives, and to enhance the coordination with debt management. This framework guided the bank in open market operations (through the treasury bill auctions) and in interventions in the foreign exchange market.

(iii) The implementation since May 1995 of the Financial Institutions Act (FIA) which aimed at ensuring the safety and soundness of the banking system by the strengthening and modernization of the regulatory and supervisory framework under which the central bank operates. The FIA expanded the central bank's supervision to all deposit-taking institutions; and raised to internationally accepted standards (Basle committee and BIS standards) the prudential requirements as to capital adequacy, loan classification and provisioning, and exposure limits on single-borrower and concentration of ownership of financial institutions.

(iv) Enhancing the bank's monetary management and economic research capacities, and improving its organization, payments, budget and audit, and information management systems with technical assistance from the Fund. Achievements in these areas included the operation and enhancement of a competitive weekly treasury bill auction system (further strengthened by the removal of limits on bid prices as of January 22, 1999); development of the statistical data base and reporting system including the compilation of the balance of payments statistics; automation of check clearing and the establishment of a National Clearing House; and introduction of a 
Foreign Exchange Market Information System (FEMIS) for bank and nonbank cambios and guidelines for banks foreign exchange risk management.

(v) Restructuring of the bank and strengthening of its human resources functions through staff training (including through participation in the courses and seminars at the IMF Institute), improving internal communication within the bank, and establishing and strengthening of the policy unit in the bank.

3. The revised Bank of Guyana Act (1998), which amended the previous Bank of Guyana Act of 1995, had originally been tabled in Parliament in 1997 but had lapsed because of the December 1997 elections. The new act recapitalized the bank, allowed the transfer of further foreign debt liabilities from its portfolio to central government, barred the bank from extending credit to the public sector, and introduced other changes to increase the efficiency and autonomy of the bank in performing its functions. Key features of the act are as follows:

(i) increased the bank's authorized and paid-up capital to G\$1 billion (from G\$6 million which has remained unchanged since the bank's establishment in 1965). The recapitalization was effected through the issuance of marketable securities by the government to the bank; these securities will be used by the bank solely for open market operations and will be rolled over upon maturity.

(ii) increased the number of the bank's directors from five to six (with the Governor and Deputy Governor appointed by the president and the rest by the minister of finance); staggered the directors' terms to expire one year apart; and empowered the Governor in consultation with the Board to appoint, reorganize, train and determine the conditions of employment of staff and consultants. Under the repealed Act, all directors were appointed simultaneously and their terms ended concurrently, and the finance minister set the terms of conditions of employees and consultants. The above-noted amendments would provide the bank with a larger measure of autonomy and continuity at the policy-making level.

(iii) allowed the transfer of foreign debt liabilities (amounting to US\$64 million) owed to non-Paris Club creditors (Argentina, Kuwait, and Libya) from the bank's books to the central government.

(iv) prohibited the bank from extending any credit (including by means of advances and negotiable securities) or guarantees directly or indirectly to the government or the public sector entities. This provision, beside helping to maintain the bank's net worth, would enhance its capacity to promote a non-inflationary macroeconomic environment. In the past, large fiscal deficits have been partly financed by credit and guarantees by the central bank. Also, the bank's quasi-fiscal activities including borrowing externally in support of the budget deficit, and making loan guarantees and 
interest payments on behalf of the Government have been largely responsible for the bank's losses and negative net worth.

(v) authorized the bank to issue and trade its own securities for the purposes of open market operations (beside trading in government securities for open market operations purposes already allowed under the previous act). This provision, together with the recapitalization of the bank, will substantially increase the bank's ability to conduct a more active monetary and exchange rate policies especially through more extensive open-market operations.

(vi) charged the bank with the sole responsibility of preparation of the balance of payments accounts and the external assets and liabilities position of the country. This formalized the practice which had been in effect for the preceding year and half, before which the compilation of the balance of payments was shared between the bank and the Bureau of Statistics (due to the inadequate technical resources at the two institutions). The provision would increase the efficiency of the balance of payments compilation and reporting and ensure greater consistency between the balance of payments and monetary accounts.

(vii) formally mandated the bank with the responsibility of the custody and management of Guyana's external reserves (denominated in foreign currency and gold).

(viii) removed the requirement that financial institutions incorporated outside Guyana should maintain a proportion ( 25 percent) of their statutory reserves in foreign exchange. The abolished requirement, which originally was intended to garner foreign exchange, has been rendered inconsistent with the liberalized exchange rate regime and the FIA regulations of creating a level playing field in the financial system.

(ix) authorized the bank to examine all records, accounts and books of licensed financial institutions and their holding companies or affiliated subsidiaries, stipulated the due notices and fines for failure to submit such information, and assured institutions of the confidentiality of the provided information. This provision seeks to ensure full disclosure and transparency of operations of financial institutions with a view to safeguarding the soundness of the individual institutions and the financial system. 


\section{Guyana: Reform of the Insurance and Securities Trading Industries}

1. Reform of the insurance and securities trading industries is an important element of the government's effort to enhance the business environment and increase the role of the private sector in the country's economic development. In December 1998 the parliament passed two bills to establish the regulatory frameworks for the insurance and securities trading industries. Two independent boards, the Insurance Commission and the Securities Council, would be formed and their respective heads appointed (by end-1999) to oversee the implementation of the two acts and monitor the activities of the insurance and securities sectors in accordance with the newly passed legislation.

2. The Insurance Act (1998): This act, drafted in collaboration with the associations of the insurers and insurance brokers in Guyana, replaced the previous insurance legislation developed in the 1970s. The act provided for the regulation of the insurance industry, including promotion of competition and consumer protection. The act opens new avenues for insurers to adequately cater for the needs of the insuring public, particularly through new products and better services.

3. Total assets of the insurance companies expanded rapidly from $\mathrm{G} \$ 398$ million in 1985 to $G \$ 10.8$ billion at mid-1998. Guyana's six insurance companies currently hold the largest share of the assets of nonbank financial institutions and can play a major role in mobilizing long-term financial resources and developing Guyana's capital market. Insurance companies have pursued conservative policies in the investment of their substantial resources, opting mainly for the safety of the foreign sector. At mid-1998, about 45 percent of insurance companies' assets were placed in foreign securities, loans and bank deposits, with the rest invested locally in the banking system (10 percent), private sector businesses (11 percent), government securities ( 1 percent), and other assets. The new act provides incentives to insurance companies to invest more in loans to local businesses (see below).

4. Key features of the new act are the following:

(i) The Commissioner of Insurance is to be invested with the power to regulate the insurance industry, a much stronger role than under the repealed act. The commissioner is appointed by, and reports directly to, the minister of finance and could be removed by him with the approval of the president. The commissioner is authorized to appoint actuaries, consultants, managers, and other staff. Under the new act, the commissioner is relieved from being the principal arbitrator in disputes between clients and insurer firms and agents, but he would be represented on an insurance arbitration board (see below).

(ii) The commissioner's office may, if necessary, supplement its budget (primarily funded by registration fees, fines and allocations by the National Assembly) through a levy assessed on the insurance industry (insurers, insurance brokers, 
underwriters association and pension fund managers under the commissioner's jurisdiction).

(iii) All insurers are required to make a deposit with the commissioner's office and maintain statutory funds. Long-term insurers (life, health, and pensions) will deposit an amount equal to G\$5 million per class of insurance business, while general insurers (accident, sickness, motor vehicles, etc.) will deposit the greater of G\$5 million or 20 percent of net premium revenue in the preceding year. In addition, insurers are required to establish a statutory fund equal to their liabilities (to policyholders) and contingency reserves (less amounts deposited with the commissioner's office). Longterm insurers are required to invest 85 percent (as against 95 percent under the previous act) of this fund in Guyana. Also, the act increased the fines for offences on companies and individuals.

The provision that all insurers should maintain statutory funds allows for greater consumer protection and corporate stability than under the repealed act, which required only long-term insurers to maintain statutory funds. Also, the new act provided incentives for companies to invest in the common stocks of the Guyanese companies by reducing the domestic investment required (from 85 percent to a minimum of 75 percent) if the insurer invested in the common stock or long-term debt of companies in Guyana. The act provides a similar incentive for the investments of funds of pension plans. These provisions are intended to coordinate the Insurance Act with the new Securities Act to promote investment in public companies in Guyana.

(iv) Two new entities for dispute resolution are to be established: (a) an Insurance Arbitration Board (composed of representatives of the commissioner, and the associations of insurance firms and brokers) to resolve disputes between policyholders and insurers, and (b) an Insurance Board of Review (IBR) to listen to appeals of the decisions of the commissioner. Appeals from the decisions of the IBR are resolved by the High Court (instead of the minister of finance under the repealed act).

(v) Insurance brokers and agents are to be directly regulated by the commissioner who is empowered to issue a code of conduct for them. This improves on the repealed act which required the commissioner to have insurance companies registered but not regulated by his office. Also, the new act authorized the commissioner to register and regulate pension plans (which previously fell under the jurisdiction of the Inland Revenue Department). This was deemed more appropriate since many pension plans are managed by insurance companies.

(vi) Policyholders are enabled to name beneficiaries and beneficiaries to collect benefits without being affected by the policyholder's will (unlike under the previous act in which benefits were paid to the estate of the insured). Also, the act introduced a provision which prevented insurers from voiding policies based on the 
state of health of the insured (except if the insured failed to disclose something or lied about the state of his health). These provisions are considered to offer consumers greater protection than under the previous act.

5. The Securities Industry Act (SIA), 1998: The act regulates the securities issuance and trading in Guyana through provisions for the registration and efficient operation of securities' issuers, brokers and dealers, and their respective associations. The act constitutes the first step in the development of a stock exchange in Guyana and repeals comparable parts of the Companies Act (1991) and the Capital Issues (Control) Act (1995). It aims to encourage long-term financing and capital formation by fostering a deeper and more efficient capital market, protecting purchasers of securities, and promoting professional and ethical conduct in the securities industry. It is expected that the act will allow wider ownership of shares by Guyanese and encourage more companies to go public to make use of available capital. Also, the act will assist in implementing transparent disclosure mechanisms for share offerings.

6. The act was modeled after the Trinidadian securities act, taking into account the local conditions, especially the relative immaturity of the Guyanese securities market (compared for instance to that of Trinidad and Tobago or Jamaica). This will increase the likelihood that the securities laws and practices developed under the act will be in harmony with those in neighboring Caricom states and enhance Guyana's interest in becoming a significant participant in the regional capital market. To enhance the effectiveness of the act, the government has mounted a campaign to inform the public of the benefits of having a securities exchange. This is particularly important in view of the fact that there is no well established securities market in Guyana and most companies are family-owned businesses. Since December 1993, a Call Exchange has been in operation, but the trading has remained thin and the exchange has been witnessing a declining turnover.

7. Key features of the act are as follows:

(i) A Securities Council will be established to administer the act and advise the minister of finance on matters relating to securities. The council will have three-five members (including an officer from the Bank of Guyana), and a chairman-all appointed by the minister of finance. The council will appoint a manager to handle day-to-day operations and will be funded from appropriations approved by parliament and from fees paid by securities' issuers and dealers, and other securities intermediaries.

(ii) Self-regulatory organizations (SRO), such as securities exchanges, clearing agencies, and associations of securities companies and intermediaries, will be recognized by the council (subject to approval by the Minister) and will be charged with the task of licensing of securities companies, dealers, and brokers. Relieving the council of the tasks of licensing and monitoring the conduct of market activities will 
reduce its administrative and financial burden and better ensure the application of substantive standards of professional and financial competency. ${ }^{1}$

(iii) Companies based in Caricom states or companies registered as foreign businesses in Guyana are eligible for registration with the council. This would promote economic regionalism within the Caricom and also encourage foreign investment and participation in the Guyanese securities market and business activity.

(iv) A self-regulatory clearing agency is to be formed for the purpose of enabling participants to trade in securities by book entry instead of physical delivery of certificates. This is expected to facilitate trading, enhance confidence and promote an efficient securities market.

(v) Comprehensive standards are set forth regarding malpractice, the conduct of business by securities professionals, insider dealings, and takeover bids. In particular, the act prohibits market rigging transactions (e.g. deceptive devices and schemes, "churning" or excessive trading in clients' accounts etc.); mandates the disclosure of certain conflicts; requires the mailing of confirmations and the maintenance of records; regulates "insider trading" by requiring persons owning more than a stipulated percentage (to be established by the council) of a reporting issuer's securities to publicly disclose the amount, nature and purpose of its ownership; and regulates certain aspects of takeover bids including requirements for public disclosure and treatment of all stockholders on equal footing (e.g. in case of excess tendering the purchase from all stockholders on a pro rata basis, or paying the best price to all tendering stockholders). The act stipulates that self-regulating organizations could not make rules (e.g. by virtue of the authority delegated to them by the council) that contravene these standards.

\footnotetext{
${ }^{1}$ This approach of assigning licensing responsibilities to self-regulatory organizations rather than to the securities council or commission is similar to that used in Trinidad and Tobago and the United States (where in the latter the principal SRO is the National Association of Securities Dealers and its affiliate Nasdaq Stock Exchange), but not in Jamaica.
} 


\section{INCOME TAX}

\section{Personal and corporate}

Individuals and corporations receiving income earned from carrying out productive activities (including the rendering of services) within the territory of the Republic of Guyana.

\section{Withholding}

Individuals and corporations

2. ENTERTAINME:TT TAX

\section{Tax base:}

\section{Personal}

The total amount of net taxable income--whether Individuals pay rates of 20 percent on annual in money or in kind--earned by the taxpayer (gross income exceeding $G \$ 216,000$ but below income less expenses and deductions).

G\$350,000 (monthly income exceeding G\$18,000 but below G\$29,083; and $331 / 3$ percent on annual income from $G \$ 350,000$ upwards (monthly income from G\$29,083 upwards).

\section{Corporate}

1. Manufacturing-noncommercial corporations pay 35 percent on net profit

2. Nonmanufacturing-commercial corporations pay 45 percent on net profit Companies pay a minimum tax of 2 percent. This is credited when they return to profitability.

Tax paid on interest earned on:
(i) Savings accounts
Fifteen percent

(ii) Other interest payments to nonresidents

(iii) Other interest payments

(iv) Payments other than interest to nonresidents

(v) Loans secured by bonds and

similar instruments

Fifteen percent

Fifteen percent

Ten percent

Fifteen percent

Deductions of tax from discount on Treasury Bills

Fifteen percent final tax.

Tax paid by gold miners (individuals only) on gross sales to the Gold Board

2 percent

Income generated from entertainment, foreign artists and cinemas

Twenty five percent

\section{Deductions:}

Threshold: G\$18,000 per month and $\$ \$ 216,000$ per year.

\section{Exempted types of income:}

1. Donations to charitable organizations

2. Dividends

3. Annual leave passage allowances to traditional public servants (which equals one month salary).

All others are taxed at the normal rate if income is not invested.

Exempted persons or entities:

1. Disabled individuals and senior citizens whose total annual income does not exceed G\$216,000

2. Charitable organizations

\section{Exempted types of income:}

1. Dividends

\section{Exempted types of income:}

Performances by Caribbean and nonresident Guyanese artists 


\section{PREMIUM}

\section{PROPERTY}

Process Fee (previously Estate Duty) Heirs or recipients of a particular items of property

\section{Capital gains}

5. PURCHASE TAX

6. TRAVEL VOUCHER TAX
Tax paid on insurance premiums to:

(i) Nonresident companies carrying on business in

Guyana

(i) Nonresident companies not carrying on

business in Guyana

6 percent

Ten percent

Tax base: Personal

(i) On the first G\$5,000,000 of net property Zero rate

(ii) For every dollar of the next $G \$ 5,000,000$ of net property

(iii) For every dollar of the remainder of the net property

$1 / 2$ percent

$3 / 4$ percent

Tax base: Corporate

(i) On the first $G \$ 5,000,000$ of net property Zero rate

(ii) For every dollar of the next G\$5,000,000 of net property

(iii) For every dollar of the remainder of the net property

$1 / 2$ percent

$3 / 4$ percent

Gifts with value exceeding G\$100,000

$1 / 2$ percent of gross value

Income gained from the sale, disposal or transfer Twenty percent of profit of capital items (e.g. vehicles, real estate

Tax paid on the accumulated retail value of vehicles purchased, based on engine capacity:
(i) Under $1500 \mathrm{cc}$
Ten percent
(ii) From $1500 \mathrm{cc}$ to $2000 \mathrm{cc}$
(iii) From $2000 \mathrm{cc}$ to $3000 \mathrm{cc}$
Twenty percent
Seventy percent
(iv) From $3000 \mathrm{cc}$ and above
One hundred percent

Tax paid on the cost of any airline ticket for which the journey originates in Guyana

Ten percent

Tax exit required to be paid by passengers departing Guyana
Disposal of public corporation shares 


\section{IMPORT DUTIES}

Any individual or corporation importing goods liable to taxation

All goods liable for taxation that are imported into

Guyana

Tax base: The c.i.f. value of the merchandise

General rates

Special rates (natural agricultural products)

Motor vehicles

Luxury items

0 to 25 percent

Forty percent

Forty five percent

One hundred percent

\section{Exempted companies}

All oil commodities imported by mining companies

Imports originated from Caricom countries

\section{EXPORT DUTIES}

Charges for specific services provided by

line departments:

Product and tax base:

Aquarium fish - value of export 5 percent

Bauxite - tonne G\$0.45

Timber

Rough green hard logs - cubic meter $\quad G \$ 0.29$

Sawn green hard wood - cubic meter G\$5.09

Live birds - value of export

Sugar - tonne

1.5 percent

G\$1 (deposited in Sugar Industry Stabilization

Fund)

\section{Tax base}

On imported commodities:

$\begin{array}{ll}\text { (i) Value of duty paid on oil imports } & \text { Fifty percent } \\ \text { (ii) Value of duty paid on nonoil imports } & 0-30 \text { percent }\end{array}$

On local goods:

(i) Selling price of alcoholic beverages Fifty percent

(ii) Production cost of tobacco 128 percent

(iii) Other goods

Primary inputs and capital goods $\quad 0.10$ percent

Intermediate inputs and final goods $\quad 15-30$ percent

On local services:

(i) Value of overseas telephone calls Ten percent

(ii) Betting shops - value of the bet Ten percent

\section{CONSUMPTION TAX}


Table 1. Guyana: Value Added by Sector

\begin{tabular}{|c|c|c|c|c|c|c|}
\hline & 1993 & 1994 & 1995 & 1996 & 1997 & $\begin{array}{r}\text { Est. } \\
1998\end{array}$ \\
\hline \multicolumn{7}{|c|}{ (In percent of GDP at current prices) } \\
\hline GDP at current factor cost & 100.0 & 100.0 & 100.0 & 100.0 & 100.0 & 100.0 \\
\hline Agriculture & 36.2 & 37.0 & 41.2 & 38.9 & 35.4 & 34.7 \\
\hline Sugar & 16.1 & 15.0 & 13.7 & 12.7 & 10.7 & 10.4 \\
\hline Rice & 5.2 & 7.0 & 11.6 & 10.4 & 8.1 & 7.9 \\
\hline Other crops & 4.5 & 4.3 & 4.8 & 4.8 & 5.0 & 5.4 \\
\hline Livestock & 1.5 & 1.5 & 1.7 & 1.9 & 2.0 & 2.0 \\
\hline Fishing & 6.8 & 6.2 & 6.1 & 5.9 & 6.2 & 6.6 \\
\hline Forestry & 2.1 & 3.1 & 3.3 & 3.2 & 3.5 & 2.4 \\
\hline Mining and quarrying & 20.7 & 21.5 & 17.0 & 18.9 & 17.3 & 16.0 \\
\hline Bauxite & 7.7 & 5.2 & 5.5 & 5.7 & 3.7 & 3.5 \\
\hline Other & 13.1 & 16.3 & 11.6 & 13.2 & 13.7 & 12.6 \\
\hline Manufacturing & 11.6 & 11.6 & 11.4 & 10.3 & 11.4 & 11.1 \\
\hline Sugar & 6.4 & 6.0 & 6.0 & 5.0 & 5.5 & 5.4 \\
\hline Rice & 1.2 & 2.0 & 1.5 & 1.6 & 2.2 & 2.3 \\
\hline Other & 4.0 & 3.6 & 3.8 & 3.7 & 3.7 & 3.4 \\
\hline Construction & 3.4 & 3.6 & 4.2 & 4.6 & 5.0 & 5.4 \\
\hline Services & 28.1 & 26.3 & 26.1 & 27.3 & 30.8 & 32.8 \\
\hline Distribution & 4.7 & 4.4 & 4.3 & 4.3 & 4.3 & 4.6 \\
\hline Transportation and communication & 5.3 & 5.2 & 5.1 & 5.5 & 5.8 & 6.7 \\
\hline Rental of dwellings & 4.4 & 3.9 & 3.8 & 3.7 & 3.9 & 3.9 \\
\hline Financial & 3.6 & 3.3 & 3.1 & 3.4 & 3.3 & 3.4 \\
\hline Government & 8.5 & 8.1 & 8.4 & 9.0 & 12.1 & 12.7 \\
\hline Other & 1.5 & 1.4 & 1.4 & 1.5 & 1.5 & 1.5 \\
\hline \multicolumn{7}{|c|}{ (Percentage change) } \\
\hline GDP at constant 1988 prices & 8.2 & 8.5 & 5.0 & 7.9 & 6.2 & -1.5 \\
\hline Agriculture & 5.9 & 12.2 & 8.5 & 7.4 & 4.0 & -5.1 \\
\hline Sugar & -0.2 & 4.0 & -0.5 & 10.4 & -1.2 & -7.5 \\
\hline Rice & 24.0 & 9.7 & 37.3 & 5.7 & 2.0 & -0.3 \\
\hline Other crops & 5.2 & 5.9 & 8.4 & 3.9 & 5.4 & 6.8 \\
\hline Livestock & 11.1 & 15.0 & 21.7 & 25.0 & 5.7 & -1.6 \\
\hline Fishing & 2.8 & 7.1 & 10.0 & 2.3 & 8.1 & 11.1 \\
\hline Forestry & 33.0 & 68.4 & 15.7 & 0.4 & 15.3 & -21.8 \\
\hline Mining and quarrying & 49.0 & 6.6 & -11.4 & 15.2 & 15.0 & 2.7 \\
\hline Bauxite & 100.0 & -48.1 & 7.8 & 0.4 & -0.4 & 3.5 \\
\hline Other & -34.4 & 278.6 & -24.5 & 29.6 & 26.7 & 2.2 \\
\hline Manufacturing & 3.3 & 5.8 & 9.4 & 5.7 & 2.4 & -8.9 \\
\hline Sugar & -0.5 & 4.4 & -1.1 & 10.1 & -1.0 & -7.5 \\
\hline Rice & 20.0 & 13.9 & 31.7 & 7.4 & 1.7 & -0.3 \\
\hline Other & 4.0 & 5.6 & 12.9 & 2.9 & 4.6 & -10.6 \\
\hline Construction & 3.5 & 20.0 & 9.7 & 14.0 & 13.1 & 4.8 \\
\hline Services & 3.4 & 5.6 & 5.3 & 6.1 & 5.3 & 0.7 \\
\hline Distribution & 7.0 & 5.9 & 5.0 & 5.1 & 5.6 & 5.2 \\
\hline Transportation and communication & 6.0 & 8.5 & 9.0 & 10.9 & 8.9 & -3.1 \\
\hline Rental of dwellings & 0.0 & 9.1 & 6.9 & 6.5 & 7.3 & 5.1 \\
\hline Financial & 4.9 & 7.9 & 7.8 & 9.6 & 4.4 & 3.3 \\
\hline Government & 0.0 & 2.0 & 2.0 & 1.9 & 2.8 & -2.0 \\
\hline Other & 3.7 & 8.6 & 6.0 & 7.5 & 5.2 & 3.7 \\
\hline
\end{tabular}

Source: Bureau of Statistics. 
Table 2. Guyana: Value Added by Sector at Current Prices

(In millions of Guyana dollars)

\begin{tabular}{lrrrrrr}
\hline & 1993 & 1994 & 1995 & 1996 & 1997 & Est. \\
\hline & & & & & & \\
GDP at current factor costs & $\mathbf{4 9 , 5 3 2}$ & $\mathbf{6 3 , 1 4 5}$ & $\mathbf{7 3 , 9 2 7}$ & $\mathbf{8 2 , 2 5 8}$ & $\mathbf{8 9 , 7 4 4}$ & $\mathbf{9 2 , 0 0 2}$ \\
Agriculture & $\mathbf{1 7 , 9 0 7}$ & 23,357 & 30,481 & 31,993 & $\mathbf{3 1 , 8 1 3}$ & 31,949 \\
Sugar & 7,973 & 9,451 & 10,136 & 10,462 & 9,608 & 9,598 \\
Rice & 2,586 & 4,415 & $\mathbf{8 , 5 6 9}$ & $\mathbf{8 , 5 3 0}$ & $\mathbf{7 , 2 8 5}$ & $\mathbf{7 , 2 4 1}$ \\
Other crops & 2,227 & 2,715 & 3,518 & $\mathbf{3 , 9 7 4}$ & 4,478 & 4,962 \\
Livestock & 731 & 916 & 1,249 & 1,598 & 1,807 & 1,879 \\
Fishing & 3,344 & 3,924 & 4,536 & 4,832 & 5,532 & 6,035 \\
Forestry & 1,046 & 1,936 & 2,473 & 2,597 & 3,103 & 2,234 \\
Mining and quarrying & 10,275 & 13,570 & 12,604 & 15,567 & 15,565 & 14,752 \\
Bauxite & 3,801 & 3,295 & 4,064 & 4,680 & 3,284 & 3,202 \\
Other & 6,474 & 10,275 & 8,540 & 10,887 & 12,281 & 11,550 \\
Manufacturing & 5,756 & 7,327 & 8,431 & 8,491 & 10,265 & 10,220 \\
Sugar & 3,166 & 3,795 & 4,472 & 4,095 & 4,952 & 4,944 \\
Rice & 613 & 1,236 & 1,113 & 1,318 & 2,016 & 2,111 \\
Other & 1,977 & 2,296 & 2,846 & 3,078 & 3,297 & 3,165 \\
Construction & 1,673 & 2,253 & 3,098 & 3,747 & 4,446 & 4,926 \\
Services & 13,921 & 16,638 & 19,313 & 22,460 & 27,655 & 30,155 \\
Distribution & 2,323 & 2,750 & 3,205 & 3,534 & 3,855 & 4,202 \\
Transportation and & & & & & & \\
$\quad$ communication & 2,645 & 3,300 & 3,742 & 4,486 & 5,183 & 6,168 \\
Rental of dwellings & 2,197 & 2,491 & 2,798 & 3,025 & 3,489 & 3,629 \\
Financial & 1,790 & 2,076 & 2,324 & 2,829 & 2,974 & 3,087 \\
Government & 4,220 & 5,115 & 6,187 & 7,393 & 10,839 & 11,662 \\
Other & 746 & 906 & 1,057 & 1,193 & 1,315 & 1,407 \\
\hline & & & & & &
\end{tabular}

Source: Bureau of Statistics. 
Table 3. Guyana: Value Added by Sector at Constant 1988 Prices

(In millions of 1988 Guyana dollars)

\begin{tabular}{lrrrrrr}
\hline & 1993 & 1994 & 1995 & 1996 & 1997 & Est. \\
\hline GDP at constant factor cost & & & & & & \\
Agriculture & $\mathbf{4 , 1 0 2}$ & $\mathbf{4 , 4 5 2}$ & $\mathbf{4 , 6 7 6}$ & $\mathbf{5 , 0 4 7}$ & $\mathbf{5 , 3 6 0}$ & $\mathbf{5 , 2 7 7}$ \\
Sugar & 1,160 & 1,301 & 1,412 & 1,516 & 1,576 & 1,495 \\
Rice & 575 & 598 & 595 & 657 & 649 & 596 \\
Other crops & 93 & 102 & 140 & 148 & 151 & 149 \\
Livestock & 203 & 215 & 233 & 242 & 255 & 272 \\
Fishing & 60 & 69 & 84 & 105 & 111 & 109 \\
Forestry & 112 & 120 & 132 & 135 & 146 & 162 \\
Mining and quarrying & 117 & 197 & 228 & 229 & 264 & 206 \\
Bauxite & 502 & 535 & 474 & 546 & 628 & 645 \\
Other & 418 & 217 & 234 & 235 & 234 & 242 \\
Manufacturing & 84 & 318 & 240 & 311 & 394 & 403 \\
Sugar & 504 & 533 & 583 & 616 & 631 & 575 \\
Rice & 182 & 190 & 188 & 207 & 205 & 188 \\
Other & 36 & 41 & 54 & 58 & 59 & 58 \\
Construction & 286 & 302 & 341 & 351 & 367 & $\mathbf{3 2 8}$ \\
Services & 265 & 318 & 349 & 398 & 450 & $\mathbf{4 7 2}$ \\
Distribution & 1,671 & 1,765 & 1,858 & 1,971 & 2,075 & 2,091 \\
Transportation and & 338 & 358 & 376 & 395 & 417 & $\mathbf{4 3 9}$ \\
$\quad$ communication & & & & & & \\
Rental of dwellings & 317 & 344 & 375 & 416 & 453 & 439 \\
Financial & 66 & 72 & 77 & 82 & 88 & 93 \\
Government & 214 & 231 & 249 & 273 & 285 & 295 \\
Other & 597 & 609 & 621 & 633 & 651 & 638 \\
\hline & 139 & 151 & 160 & 172 & 181 & 188 \\
\hline
\end{tabular}

Source: Bureau of Statistics. 
Table 4. Guyana: GDP by Expenditure at Current Prices

\begin{tabular}{|c|c|c|c|c|c|c|}
\hline & 1993 & 1994 & 1995 & 1996 & 1997 & $\begin{array}{r}\text { Est } \\
1998\end{array}$ \\
\hline \multicolumn{7}{|c|}{ (In millions of Guyana dollars) } \\
\hline GDP at current factor cost & 49,532 & 63,145 & 73,927 & 82,258 & 89,744 & 92,002 \\
\hline Net indirect taxes $1 /$ & 8,052 & 11,658 & 14,176 & 16,296 & 16,933 & 16,464 \\
\hline GDP at market prices & 57,584 & 74,803 & 88,103 & 98,554 & 106,677 & 108,465 \\
\hline Consumption expenditure & 45,109 & 64,147 & 69,729 & 76,284 & 84,687 & 89,957 \\
\hline Private sector & 36,125 & 52,966 & 56,639 & 60,516 & 66,441 & 70,843 \\
\hline Public sector & 8,984 & 11,181 & 13,090 & 15,768 & 18,246 & 19,114 \\
\hline Gross domestic investment & 23,903 & 20,364 & 28,001 & 29,710 & 32,372 & 31,144 \\
\hline Private sector & 12,718 & 11,677 & 13,649 & 10,842 & 13,101 & 15,478 \\
\hline Public sector & 11,185 & 8,687 & 14,352 & 18,868 & 19,271 & 15,666 \\
\hline \multicolumn{7}{|l|}{ Net exports of goods and } \\
\hline nonfactor services & $-11,428$ & $-9,708$ & $-9,627$ & $-7,440$ & $-10,382$ & $-12,637$ \\
\hline \multicolumn{7}{|l|}{ Exports of goods and } \\
\hline \multicolumn{7}{|l|}{ Imports of goods and } \\
\hline nonfactor services & $-79,020$ & $-88,215$ & $-98,966$ & $-107,668$ & $-115,784$ & $-116,557$ \\
\hline \multicolumn{7}{|c|}{ (As a percentage of GDP at market prices) } \\
\hline GDP at current factor cost & 86.0 & 84.4 & 83.9 & 83.5 & 84.1 & 84.8 \\
\hline Net indirect taxes $1 /$ & 14.0 & 15.6 & 16.1 & 16.5 & 15.9 & 15.2 \\
\hline GDP at market prices & 100.0 & 100.0 & 100.0 & 100.0 & 100.0 & 100.0 \\
\hline Consumption expenditure & 78.3 & 85.8 & 79.1 & 77.4 & 79.4 & 82.9 \\
\hline Private sector & 62.7 & 70.8 & 64.3 & 61.4 & 62.3 & 65.3 \\
\hline Public sector & 15.6 & 14.9 & 14.9 & 16.0 & 17.1 & 17.6 \\
\hline Gross domestic investment & 41.5 & 27.2 & 31.8 & 30.1 & 30.3 & 28.7 \\
\hline Private sector & 22.1 & 15.6 & 15.5 & 11.0 & 12.3 & 14.3 \\
\hline Public sector & 19.4 & 11.6 & 16.3 & 19.1 & 18.1 & 14.4 \\
\hline \multicolumn{7}{|l|}{ Net exports of goods and } \\
\hline nonfactor services & -19.8 & -13.0 & -10.9 & -7.5 & -9.7 & -11.7 \\
\hline \multicolumn{7}{|l|}{ Exports of goods and } \\
\hline nonfactor services & 117.4 & 105.0 & 101.4 & 101.7 & 98.8 & 95.8 \\
\hline \multicolumn{7}{|l|}{ Imports of goods and } \\
\hline nonfactor services & -137.2 & -117.9 & -112.3 & -109.2 & -108.5 & -107.5 \\
\hline
\end{tabular}

Sources: Bureau of Statistics; Bank of Guyana; and Fund staff estimates.

1/Including errors and omissions. 
Table 5. Guyana: Savings and Investment

\begin{tabular}{|c|c|c|c|c|c|c|}
\hline & 1993 & 1994 & 1995 & 1996 & 1997 & $\begin{array}{r}\text { Est. } \\
1998 \\
\end{array}$ \\
\hline \multicolumn{7}{|c|}{ (In millions of Guyana dollars) } \\
\hline Savings & 23,903 & 20,364 & 28,001 & 29,710 & 32,372 & 31,144 \\
\hline National savings & 7,372 & 6,535 & 12,240 & 20,585 & 17,276 & 16,401 \\
\hline Private savings & 8,333 & 2,124 & 1,400 & 4,922 & 7,298 & 6,578 \\
\hline Public savings & 961 & 4,411 & 10,840 & 15,663 & 9,978 & 9,824 \\
\hline Foreign savings & 16,530 & 13,829 & 15,761 & 9,124 & 15,096 & 14,743 \\
\hline Investment & 23,903 & 20,364 & 28,001 & 29,710 & 32,372 & 31,144 \\
\hline Private investment & 12,718 & 11,677 & 13,649 & 10,842 & 13,101 & 15,478 \\
\hline Public investment & 11,185 & 8,687 & 14,352 & 18,868 & 19,271 & 15,666 \\
\hline \multicolumn{7}{|c|}{ (In percent of GDP at market prices) } \\
\hline Savings & 41.5 & 27.2 & 31.8 & 30.1 & 30.3 & 28.7 \\
\hline National savings & 12.8 & 8.7 & 13.9 & 20.9 & 16.2 & 15.1 \\
\hline Private savings & 14.5 & 2.8 & 1.6 & 5.0 & 6.8 & 6.1 \\
\hline Public savings & -1.7 & 5.9 & 12.3 & 15.9 & 9.4 & 9.1 \\
\hline Foreign savings & 29.4 & 18.9 & 17.9 & 9.3 & 14.2 & 13.6 \\
\hline Investment & 41.5 & 27.2 & 31.8 & 30.1 & 30.3 & 28.7 \\
\hline Private investment & 22.1 & 15.6 & 15.5 & 11.0 & 12.3 & 14.3 \\
\hline Public investment & 19.4 & 11.6 & 16.3 & 19.1 & 18.1 & 14.4 \\
\hline
\end{tabular}

Sources: Bureau of Statistics; Bank of Guyana; and Fund staff estimates. 
Table 6. Guyana: Consumer Prices

(Percentage change, period average)

\begin{tabular}{|c|c|c|c|c|c|c|c|}
\hline & $\begin{array}{l}\text { Weight } \\
\text { in New } \\
\text { Consump- } \\
\text { tion Basket }\end{array}$ & $19931 /$ & 1994 & 1995 & 1996 & 1997 & 1998 \\
\hline $\begin{array}{l}\text { Urban consumer prices } \\
\text { (Georgetown) }\end{array}$ & 100.0 & 120 & 136 & 122 & 71 & 36 & 46 \\
\hline Food & 44.1 & $\ldots$ & $\ldots$ & $\ldots$ & 7.6 & 0.8 & 3.6 \\
\hline Clothing & 3.7 & $\ldots$ & $\ldots$ & $\ldots$ & -1.1 & -3.4 & -8.5 \\
\hline Footwear & 1.9 & $\ldots$ & $\ldots$ & $\ldots$ & -3.2 & -3.1 & -10.4 \\
\hline Housing & 22.8 & $\ldots$ & $\ldots$ & $\ldots$ & 12.2 & 8.8 & -1.0 \\
\hline Furniture & 6.0 & $\ldots$ & $\ldots$ & $\ldots$ & 1.5 & 4.8 & -1.1 \\
\hline $\begin{array}{l}\text { Transport and } \\
\text { communications }\end{array}$ & 10.8 & $\ldots$ & $\ldots$ & $\ldots$ & 2.5 & 5.6 & 28.5 \\
\hline $\begin{array}{l}\text { Medical and } \\
\text { personal care }\end{array}$ & 2.4 & $\ldots$ & $\ldots$ & $\ldots$ & 11.9 & 3.5 & 10.7 \\
\hline Education, recreation, culture & 3.5 & $\ldots$ & $\ldots$ & $\ldots$ & 4.8 & 6.0 & 4.7 \\
\hline Other & 4.8 & $\ldots$ & $\ldots$ & $\ldots$ & 2.7 & 2.2 & 4.3 \\
\hline
\end{tabular}

Sources: Bureau of Statistics; and Fund staff estimates.

1/ Staff estimates of the inflation rate are based on price data collected by the Bureau of Statistics representing about 60 percent of the old CPI basket for 1991-93. Publication of the consumer price index was resumed in 1994. 
Table 7. Guyana: Population Estimates

(In thousands)

\begin{tabular}{lcccccc}
\hline & 1993 & 1994 & 1995 & 1996 & 1997 & 1998 \\
\hline Midyear & 734.9 & 746.0 & 760.4 & 770.1 & 775.1 & 773.4 \\
Natural increase 1/ & 15.0 & 16.5 & 17.3 & 16.9 & -20.2 & $\ldots$ \\
Net migration & -7.0 & 0.3 & -7.5 & -12.6 & -16.3 & $\ldots$ \\
\hline
\end{tabular}

Source: Bureau of Statistics.

1/ Total births minus total deaths. 
Table 8. Guyana: Employment in the Public Sector

\begin{tabular}{|c|c|c|c|c|c|c|}
\hline & 1993 & 1994 & 1995 & 1996 & 1997 & $\begin{array}{r}\text { Prel. } \\
1998 \\
\end{array}$ \\
\hline \multicolumn{7}{|c|}{ (Number of employees) } \\
\hline Total public sector $1 /$ & 56,132 & $\mathbf{5 0 , 4 9 2}$ & 46,671 & 42,122 & $\mathbf{3 8 , 8 2 0}$ & 36,269 \\
\hline Central government & 15,899 & 14,564 & 12,913 & 12,393 & 10,792 & 9,419 \\
\hline Rest of the public sector & 40,233 & 35,928 & 33,758 & 29,729 & 28,028 & 26,850 \\
\hline Guyana State Corporation (GUYSTAC Group) & 6,945 & 6,394 & 5,116 & 4,901 & 4,666 & 4,295 \\
\hline Guyana Rice Group & 249 & 215 & 352 & 386 & 318 & 349 \\
\hline \multicolumn{7}{|l|}{ Guyana National Engineering Corporation } \\
\hline (GNEC) & 870 & 649 & 29 & 32 & 31 & 20 \\
\hline Guyana Stores Limited (GSL) & 1,101 & 1,031 & 867 & 776 & 601 & 590 \\
\hline Guyana Electricity Corporation & 1,775 & 1,530 & 1,096 & 1,105 & 1,216 & 1,328 \\
\hline Guyana Pharmaceutical Corporation & 336 & 318 & 247 & 225 & 225 & 195 \\
\hline Other corporations & 2,614 & 2,651 & 2,525 & 2,377 & 2,275 & 1,813 \\
\hline Guyana Sugar Corporation (GUYSUCO) $2 /$ & 27,855 & 24,463 & 23,819 & 20,492 & 19,287 & 18,873 \\
\hline Bauxite companies & 3,303 & 3,020 & 2,866 & 2,648 & 2,390 & 2,115 \\
\hline Linden Mining Enterprise (LINMINE) & 2,389 & 2,133 & 2,000 & 1,861 & 1,746 & 1,568 \\
\hline Berbice Mining Enterprise (BERMINE) & 914 & 887 & 866 & 787 & 644 & 547 \\
\hline Other independent corporations & 243 & 236 & 243 & 232 & 230 & 240 \\
\hline Guyana Broadcasting Corporation & 137 & 110 & 112 & 107 & 105 & 111 \\
\hline Guyana National Newspaper Limited & 106 & 126 & 131 & 125 & 125 & 129 \\
\hline Financial institutions & 1,887 & 1,815 & 1,714 & 1,456 & 1,455 & 1,327 \\
\hline \multicolumn{7}{|c|}{ (In percent of total) } \\
\hline Central government & 28.3 & 28.8 & 27.7 & 29.4 & 27.8 & $\mathbf{2 6 . 0}$ \\
\hline Rest of the public sector & 71.7 & 71.2 & 72.3 & 70.6 & 72.2 & 74.0 \\
\hline Guyana State Corporation (GUYSTAC Group) & 12.4 & 12.7 & 11.0 & 11.6 & 12.0 & 11.8 \\
\hline Guyana Sugar Corporation (GUYSUCO) & 49.6 & 48.4 & 51.0 & 48.6 & 49.7 & 52.0 \\
\hline Bauxite companies $1 /$ & 5.9 & 6.0 & 6.1 & 6.3 & 6.2 & 5.8 \\
\hline Linden Mining Enterprise (LINMINE) & 4.3 & 4.2 & 4.3 & 4.4 & 4.5 & 4.3 \\
\hline Berbice Mining Enterprise (BERMINE) & 1.6 & 1.8 & 1.9 & 1.9 & 1.7 & 1.5 \\
\hline Other independent corporations & 0.4 & 0.5 & 0.5 & 0.6 & 0.6 & 0.7 \\
\hline Financial institutions & 3.4 & 3.6 & 3.7 & 3.5 & 3.7 & 3.7 \\
\hline \multicolumn{7}{|c|}{ (12-month percentage change) } \\
\hline Central government & $\ldots$ & -8.4 & -11.3 & -4.0 & -12.9 & -12.7 \\
\hline Rest of public sector & $\ldots$ & -10.7 & -6.0 & -11.9 & -5.7 & -4.2 \\
\hline
\end{tabular}

Sources: Bureau of Statistics; and State Planning Secretariat.

1/ Excludes staff of the Guyana Police Force, Guyana Defense Force, Guyana Fire Service, Guyana Prison Service, Guyana National Service, Teachers, Open Vote Workers, and staff of entities receiving subsidies and contributions.

2/ Employment figures represent permanent employees. Guysuco has also employed temporary workers totaling 1,537, 1,529, and 2,250 in 1996,1997 , and 1998, respectively. 
Table 9. Guyana: Summary of the Operations of the Public Sector

\begin{tabular}{|c|c|c|c|c|c|c|}
\hline & 1993 & 1994 & 1995 & 1996 & 1997 & $\begin{array}{r}\text { Prel. } \\
1998 \\
\end{array}$ \\
\hline \multicolumn{7}{|c|}{ (In millions of Guyana dollars) } \\
\hline Revenue & 17,248 & 23,582 & 32,996 & 39,298 & $\mathbf{3 8 , 7 8 7}$ & 38,329 \\
\hline Central government & 21,973 & 23,918 & 29,317 & 34,307 & 33,999 & 33,028 \\
\hline Public enterprises 1/ & 94 & 3,081 & 5,249 & 5,963 & 4,390 & 4,843 \\
\hline Central bank $1 /$ & $-4,820$ & $-3,417$ & $-1,571$ & -972 & 398 & 458 \\
\hline Total expenditure & 29,394 & 27,858 & 36,507 & 42,445 & 48,080 & 43,843 \\
\hline Current expenditure $2 /$ & 18,209 & 19,171 & 22,155 & 23,578 & 28,809 & 28,177 \\
\hline Noninterest current expenditure & 12,009 & 11,588 & 13,246 & 16,058 & 18,709 & 19,500 \\
\hline Interest & 6,200 & 7,583 & 8,909 & 7,520 & 10,100 & 8,677 \\
\hline External & 2,688 & 2,803 & 3,234 & 2,813 & 6,485 & 5,649 \\
\hline Domestic & 3,512 & 4,780 & 5,675 & 4,708 & $.3,615$ & 3,028 \\
\hline Capital expenditure & 11,185 & 8,687 & 14,352 & 18,867 & 19,271 & 15,666 \\
\hline Central government & 8,114 & 7,580 & 12,270 & 15,640 & 16,635 & 12,657 \\
\hline State corporations and NIS & 3,071 & 1,107 & 2,082 & 3,227 & 2,637 & 3,009 \\
\hline Current balance & -961 & $4, \mathbf{4 1 1}$ & 10,840 & 15,663 & 9,978 & 10,152 \\
\hline Overall balance & $-12,146$ & $-4,276$ & $-\mathbf{3 , 5 1 1}$ & $-3,147$ & $-9,293$ & $-5,515$ \\
\hline Grants & 2,708 & 3,477 & 1,680 & 4,351 & 6,097 & 1,758 \\
\hline Overall balance after grants & $-9,438$ & -799 & $-\mathbf{1 , 8 3 1}$ & 1,203 & $-3,196$ & $-3,756$ \\
\hline Total financing & 9,438 & 799 & $\mathbf{1 , 8 3 1}$ & $-1,203$ & 3,196 & 3,756 \\
\hline Net foreign financing & 5,742 & $-1,083$ & 1,512 & 5,997 & 1,383 & 1,999 \\
\hline PSIP loans & 7,325 & 3,135 & 4,620 & 5,584 & 5,237 & 5,079 \\
\hline Other loans & 2,394 & 399 & 1,120 & 5,164 & 3,266 & 4,442 \\
\hline \multicolumn{7}{|l|}{ Of which } \\
\hline Banking system & $-8,867$ & $-6,622$ & 361 & $-8,280$ & 1,972 & 4,561 \\
\hline Divestment & 1,090 & 2,948 & 2,034 & 401 & 2,128 & 360 \\
\hline Other domestic & 11,473 & 5,556 & $-2,076$ & 679 & $-2,288$ & $-3,164$ \\
\hline \multicolumn{7}{|c|}{ (In percent of GDP) } \\
\hline Total revenue & 30.0 & 31.5 & 37.5 & 39.9 & 36.4 & 35.3 \\
\hline Total expenditure & 51.0 & 37.2 & 41.4 & 43.1 & 45.1 & 40.4 \\
\hline Current expenditure & 31.6 & 25.6 & 25.1 & 23.9 & 27.0 & 26.0 \\
\hline Interest & 10.8 & 10.1 & 10.1 & 7.6 & 9.5 & 8.0 \\
\hline External & 4.7 & 3.7 & 3.7 & 2.8 & 6.1 & 5.2 \\
\hline Domestic & 6.1 & 6.4 & 6.4 & 4.8 & 3.4 & 2.8 \\
\hline Current balance & -1.7 & 5.9 & 12.3 & 15.9 & 9.4 & 9.4 \\
\hline Capital expenditure & 19.4 & 11.6 & 16.3 & 19.1 & 18.1 & 14.4 \\
\hline Overall balance & -21.1 & -5.7 & -4.0 & -3.2 & -8.7 & -5.1 \\
\hline Grants & 4.7 & 4.6 & 1.9 & 4.4 & 5.7 & 1.6 \\
\hline Overall balance after grants & -16.4 & .1 .1 & -2.1 & 1.2 & -3.0 & -3.5 \\
\hline Net foreign financing & 10.0 & -1.4 & 1.7 & 6.1 & 1.3 & 1.8 \\
\hline Net domestic financing & 6.4 & 2.5 & 0.4 & -7.3 & 1.7 & 1.6 \\
\hline
\end{tabular}

Sources: Ministry of Finance; and Fund staff estimates.

1/ Current account balance.

2/ Current expenditure of the central government. 
Table 10. Guyana: Operations of the Central Government

\begin{tabular}{|c|c|c|c|c|c|c|}
\hline & 1993 & 1994 & 1995 & 1996 & 1997 & $\begin{array}{r}\text { Prel. } \\
1998 \\
\end{array}$ \\
\hline \multicolumn{7}{|c|}{ (In millions of Guyana dollars) } \\
\hline Tax revenue & 20,545 & 22,294 & 27,650 & 31,879 & 31,538 & 31,075 \\
\hline Income 1/ & 6,854 & 7,994 & 10,749 & 12,615 & 12,193 & 11,854 \\
\hline Property & 422 & 432 & 537 & 686 & 660 & 613 \\
\hline Consumption $1 /$ & 6,570 & 8,090 & 9,958 & 11,550 & 11,667 & 11,445 \\
\hline Intemational transactions $1 /$ & 3,266 & 3,458 & 4,113 & 4,641 & 4,383 & 4,481 \\
\hline Other & 3,432 & 2,320 & 2,293 & 2,387 & 2,635 & 2,682 \\
\hline Nontax revenue $1 /$ & 1,429 & 1,624 & 1,667 & 2,427 & 2,461 & 1,954 \\
\hline Total expenditure & 26,323 & 26,751 & 34,425 & 39,218 & 45,444 & 41,833 \\
\hline Current expenditures & 18,209 & 19,171 & 22,155 & 23,578 & 28,809 & 28,177 \\
\hline Personal emoluments & 3,585 & 4,485 & 5,514 & 6,477 & 8,298 & 9,124 \\
\hline Other goods and services & 3,486 & 4,901 & 5,476 & 6,397 & 6,140 & 6,253 \\
\hline Transfer payments & 4,938 & 2,202 & 2,256 & 3,184 & 4,271 & 4,123 \\
\hline Interest $2 /$ & 6,200 & 7,583 & 8,909 & 7,520 & 10,100 & 8,677 \\
\hline Domestic & 3,512 & 4,780 & 5,675 & 4,708 & 3,615 & 3,028 \\
\hline External & 2,688 & 2,803 & 3,234 & 2,813 & 6,485 & 5,649 \\
\hline Current account surplus or deficit $(-)$ & 3,765 & 4,746 & 7,162 & 10,673 & 5,191 & $-28,177$ \\
\hline Capital expenditure 3/ & 8,114 & 7,580 & 12,270 & 15,640 & 16,635 & 13,656 \\
\hline Overall surplus or deficit $(-)$ & $-4,349$ & $-2,834$ & $-5,108$ & $-4,911$ & $-11,444$ & $-41,833$ \\
\hline Grants & 2,708 & 3,477 & 1,680 & 4,351 & 6,097 & 1,758 \\
\hline \multicolumn{7}{|l|}{ Overall surplus or deficit (-) } \\
\hline after grants & $-1,642$ & 643 & $-3,428$ & -560 & $-5,347$ & $-40,075$ \\
\hline \multicolumn{7}{|c|}{ (In percent of GDP) } \\
\hline Total revenue & 38.2 & 32.0 & 33.3 & 34.8 & 31.9 & 30.5 \\
\hline Current revenue & 38.2 & 32.0 & 33.3 & 34.7 & 31.9 & 30.5 \\
\hline \multicolumn{7}{|l|}{ Of which } \\
\hline Tax revenue & 35.7 & 29.8 & 31.4 & 32.3 & 29.6 & 28.6 \\
\hline Nontax revenue & 2.5 & 2.2 & 1.9 & 2.4 & 2.3 & 1.8 \\
\hline Capital revenues & 0.0 & 0.0 & 0.0 & 0.1 & 0.0 & 0.0 \\
\hline Current expenditure & 31.6 & 25.6 & 25.1 & 23.9 & 27.0 & 26.0 \\
\hline \multicolumn{7}{|l|}{ Of which } \\
\hline Interest & 10.8 & 10.1 & 10.1 & 7.6 & 9.5 & 8.0 \\
\hline Noninterest current expenditures & 20.9 & 15.5 & 15.0 & 16.3 & 17.5 & 18.0 \\
\hline Current balance & 6.5 & 6.3 & 8.1 & 10.8 & 4.9 & 4.5 \\
\hline Capital expenditure & 14.1 & 10.1 & 13.9 & 15.9 & 15.6 & 12.6 \\
\hline Overall surplus or deficit (-) & -7.6 & -3.8 & -5.8 & -5.0 & -10.7 & -8.1 \\
\hline Grants & 4.7 & 4.6 & 1.9 & 4.4 & 5.7 & 1.6 \\
\hline \multicolumn{7}{|l|}{ Overall surplus or deficit (-) } \\
\hline after grants & -2.9 & 0.9 & -3.9 & -0.6 & -5.0 & -6.5 \\
\hline
\end{tabular}

Sources: Ministry of Finance; and Fund staff estimates.

1/ Includes taxes paid by state enterprises.

2/ Cash payments.

3/ Includes on lending to public enterprises. 
Table 11. Guyana: Central Government Revenues

\begin{tabular}{|c|c|c|c|c|c|c|}
\hline & 1993 & 1994 & 1995 & 1996 & 1997 & $\begin{array}{c}\text { Prel. } \\
1998 \\
\end{array}$ \\
\hline \multicolumn{7}{|c|}{ (In millions of Guyana dollars) } \\
\hline 'Total revenue & 21,973 & 23,918 & 29,317 & $\mathbf{3 4 , 3 0 7}$ & 33,999 & 33,028 \\
\hline Tax revenues & 20,545 & 22,294 & 27,650 & 31,879 & 31,538 & 31,075 \\
\hline Income tax & 6,854 & 7,994 & 10,749 & 12,615 & 12,193 & 11,854 \\
\hline Companies 1/ & 3,772 & 4,071 & 5,453 & 6,966 & 6,532 & 6,096 \\
\hline Personal & 2,184 & 3,194 & 4,230 & 4,546 & 4,558 & 4,759 \\
\hline Withholding tax & 897 & 729 & 1,066 & 1,103 & 1,103 & 999 \\
\hline Property tax & 422 & 432 & 537 & 686 & 660 & 613 \\
\hline Property & 242 & 349 & 411 & 484 & 468 & 430 \\
\hline Estate duty & 16 & 17 & 17 & 15 & 21 & 29 \\
\hline Capital gains tax & 164 & 66 & 109 & 188 & 170 & 154 \\
\hline Consumption and purchase taxes $1 /$ & 6,570 & 8,090 & 9,958 & 11,550 & 11,667 & 11,445 \\
\hline Excise tax & 168 & 49 & 0 & 0 & 0 & 0 \\
\hline Consumption tax & 6,148 & 7,747 & 9,623 & 11,087 & 11,225 & 11,003 \\
\hline On imports 1/ & 4,885 & 5,702 & 6,830 & 7,751 & 7,902 & 8,098 \\
\hline On local goods $1 /$ & 1,263 & 2,045 & 2,794 & 3,336 & 3,323 & 2,905 \\
\hline Purchiase tax on cars & 254 & 294 & 335 & 463 & 442 & 442 \\
\hline Taxes on international trade $1 /$ & 3,266 & 3,458 & 4,113 & 4,641 & 4,383 & 4,481 \\
\hline Import duties 1/ & 2,689 & 2,848 & 3,408 & 3,747 & 3,701 & 3,724 \\
\hline Export duties & 152 & 181 & 130 & 197 & 9 & 5 \\
\hline Travel tax & 425 & 429 & 575 & 697 & 673 & 752 \\
\hline Other taxes & 3,432 & 2,320 & 2,293 & 2,387 & 2,635 & 2,682 \\
\hline Sugar levy & 3,152 & 2,000 & 1,900 & 1,850 & 2,000 & 2,000 \\
\hline Entertainment tax & 37 & 32 & 40 & 46 & 34 & 29 \\
\hline Other taxes & 128 & 148 & 217 & 206 & 294 & 309 \\
\hline Vehicle licences & 76 & 87 & 94 & 168 & 160 & 215 \\
\hline Other licenses & 38 & 53 & 43 & 118 & 147 & 129 \\
\hline Nontax revenue & 1,429 & 1,624 & 1,667 & 2,428 & 2,461 & 1,954 \\
\hline Rents and royalties & 441 & 662 & 508 & 692 & 1,033 & 699 \\
\hline Fees, fines, and charges & 231 & 199 & 296 & 295 & 399 & 327 \\
\hline Rice levy & 9 & 92 & 108 & 94 & 32 & 0 \\
\hline Other nontax revenue & 748 & 671 & 755 & 1,347 & 996 & 928 \\
\hline Bank of Guyana profits & 5 & 0 & 0 & 0 & 0 & 149 \\
\hline Dividends from NFPEs & 165 & 128 & 64 & 103 & 77 & 145 \\
\hline Special transfers, corporations & 18 & 20 & 150 & 438 & 184 & 34 \\
\hline Miscellaneous & 560 & 523 & 541 & 806 & 735 & 600 \\
\hline \multicolumn{7}{|c|}{ (Annual percentage change) } \\
\hline Total revenue & 26.1 & 8.8 & 22.6 & 17.0 & -0.9 & -2.9 \\
\hline Tax revenue & 24.2 & 8.5 & 24.0 & 15.3 & -1.1 & -1.5 \\
\hline Income & 24.2 & 8.5 & 24.0 & 15.3 & -1.1 & -1.5 \\
\hline Property & 152.8 & 2.4 & 24.1 & 27.9 & -3.9 & -7.1 \\
\hline Consumption & 37.4 & 23.1 & 23.1 & 16.0 & 1.0 & -1.9 \\
\hline International trade & 58.8 & 5.9 & 19.0 & 12.8 & -5.6 & 2.2 \\
\hline Other & -8.1 & -32.4 & -1.1 & 4.1 & 10.4 & 1.8 \\
\hline Nontax revenues & 61.5 & 13.7 & 2.6 & 42.2 & 3.8 & -20.6 \\
\hline \multicolumn{7}{|c|}{ (In percent of GDP) } \\
\hline Total revenue & 38.2 & 32.0 & 33.3 & 34.8 & 31.9 & 30.5 \\
\hline Tax revenue & 35.7 & 29.8 & 31.4 & 32.3 & 29.6 & 28.6 \\
\hline Income & 11.9 & 10.7 & 12.2 & 12.8 & 11.4 & 10.9 \\
\hline Property & 0.7 & 0.6 & 0.6 & 0.7 & 0.6 & 0.6 \\
\hline Consumption & 11.4 & 10.8 & 11.3 & 11.7 & 10.9 & 10.6 \\
\hline International trade & 5.7 & 4.6 & 4.7 & 4.7 & 4.1 & 4.1 \\
\hline Other & 6.0 & 3.1 & 2.6 & 2.4 & 2.5 & 2.5 \\
\hline Nontax revenues & 2.5 & 2.2 & 1.9 & 2.5 & 2.3 & 1.8 \\
\hline
\end{tabular}

Sources: Ministry of Finance; and Fund staff estimates.

1/ Includes revenue from nonfinancial public corporations. 
Table 12. Guyana: Central Government Expenditures

\begin{tabular}{|c|c|c|c|c|c|c|}
\hline & 1993 & 1994 & 1995 & 1996 & 1997 & $\begin{array}{r}\text { Prel. } \\
1998 \\
\end{array}$ \\
\hline \multicolumn{7}{|c|}{ (In millions of Guyana dollars) } \\
\hline Total expenditure and net lending & 26,323 & 26,751 & 34,425 & 39,218 & 45,444 & 41,833 \\
\hline Current expenditure & 18,209 & 19,171 & 22,155 & 23,578 & 28,809 & 28,177 \\
\hline Goods and services & 7,071 & 9,386 & 10,990 & 12,874 & 14,438 & 18,248 \\
\hline Personnel emoluments & 3,585 & 4,485 & 5,514 & 6,477 & 8,298 & 9,124 \\
\hline Wages and salaries & 2,586 & 3,390 & 4,193 & 5,019 & 6,280 & 7,085 \\
\hline Allowances and contributions & 999 & 1,095 & 1,322 & 1,458 & 2,018 & 2,039 \\
\hline Other goods and services & 3,486 & 4,901 & 5,476 & 6,397 & 6,140 & 6,253 \\
\hline Materials and supplies & 607 & 805 & 941 & 1,010 & 1,128 & 1,354 \\
\hline Maintenance of infrastructure & 442 & 476 & 470 & 453 & 477 & 398 \\
\hline Other $1 /$ & 2,436 & 3,620 & 4,065 & 4,934 & 4,535 & 4,501 \\
\hline Interest 2/ & 6,200 & 7,583 & 8,909 & 7,520 & 10,100 & 8,677 \\
\hline External & 2,688 & 2,803 & 3,234 & 2,813 & 6,485 & 5,649 \\
\hline Domestic & 3,512 & 4,780 & 5,675 & 4,708 & 3,615 & 3,028 \\
\hline Transfers & 4,938 & 2,202 & 2,256 & 3,184 & 4,271 & 4,123 \\
\hline Public corporations & 1,903 & 0 & 0 & 0 & $\mathbf{0}$ & 0 \\
\hline Pensions and gratuities & 135 & 168 & 224 & 379 & 1,185 & 1,122 \\
\hline Other private & 1,363 & 682 & 454 & 668 & 801 & 842 \\
\hline Local and international organizations & 1,493 & 1,208 & 1,414 & 1,951 & 2,188 & 2,015 \\
\hline Local authorities & 44 & 144 & 164 & 186 & 97 & 143 \\
\hline Refund of revenues & 130 & 174 & 100 & 0 & 0 & 0 \\
\hline Capital expenditure & 8,114 & 7,580 & 12,270 & 15,640 & 16,635 & 13,656 \\
\hline \multicolumn{7}{|c|}{ (Annual percentage change) } \\
\hline Total expenditure & 18.3 & 1.6 & 28.7 & 13.9 & 15.9 & -7.9 \\
\hline Current expenditure & 14.8 & 5.3 & 15.6 & 6.4 & 22.2 & -2.2 \\
\hline Personnel emoluments & 13.5 & 25.1 & 22.9 & 17.5 & 28.1 & 10.0 \\
\hline Other goods and services & 5.0 & 40.6 & 11.7 & 16.8 & -4.0 & 1.8 \\
\hline Interest & -4.7 & 22.3 & 17.5 & -15.6 & 34.3 & -14.1 \\
\hline Transfers & 71.4 & -55.4 & 2.5 & 41.1 & 34.1 & -3.5 \\
\hline Capital expenditure & 27.2 & -6.6 & 61.9 & 27.5 & 6.4 & -17.9 \\
\hline \multicolumn{7}{|c|}{ (In percent of GDP) } \\
\hline Total expenditure & $\mathbf{4 5 . 7}$ & 35.8 & 39.1 & 39.8 & 42.6 & 38.6 \\
\hline Current expenditures & 31.6 & 25.6 & 25.1 & 23.9 & 27.0 & 26.0 \\
\hline Personnel emoluments & 6.2 & 6.0 & 6.3 & 6.6 & 7.8 & 8.4 \\
\hline Wages and salaries & 4.5 & 4.5 & 4.8 & 5.1 & 5.9 & 6.5 \\
\hline Allowances and contributions & 1.7 & 1.5 & 1.5 & 1.5 & 1.9 & 1.9 \\
\hline Other goods and services & 6.1 & 6.6 & 6.2 & 6.5 & 5.8 & 5.8 \\
\hline Interest & 10.8 & 10.1 & 10.1 & 7.6 & 9.5 & 8.0 \\
\hline Current transfers & 8.6 & 2.9 & 2.6 & 3.2 & 4.0 & 3.8 \\
\hline Capital expenditures & 14.1 & 10.1 & 13.9 & 15.9 & 15.6 & 12.6 \\
\hline
\end{tabular}

Sources: Ministry of Finance; and Fund staff estimates.

1/ Includes rent, electricity, fuel, travel, postage, telephones, and other miscellaneous expenses.

2/ Interest paid. 
Table 13. Guyana: Summary of the Operations of the Public Enterprises

\begin{tabular}{|c|c|c|c|c|c|c|}
\hline & 1993 & 1994 & 1995 & 1996 & 1997 & $\begin{array}{c}\text { Prel. } \\
1998 \\
\end{array}$ \\
\hline \multicolumn{7}{|c|}{ (In millions of Guyana dollars) } \\
\hline Revenue & 39,115 & 42,753 & 48,447 & 52,398 & 52,366 & 50,279 \\
\hline Enterprises & 37,772 & 40,853 & 45,732 & 49,067 & 48,344 & 45,063 \\
\hline NIS & 1,343 & 1,900 & 2,715 & 3,331 & 4,022 & 5,216 \\
\hline Total noninterest expenditure & 38,894 & 39,629 & 42,998 & 46,251 & 47,930 & 45,354 \\
\hline Enterprises & 33,246 & 35,268 & 38,643 & 41,294 & 43,059 & 39,589 \\
\hline Wages and salaries & 8,404 & 9,979 & 10,651 & 11,357 & 14,373 & 13,042 \\
\hline Goods and services & 24,750 & 24,990 & 26,817 & 27,954 & 28,221 & 26,007 \\
\hline Local taxes & 92 & 300 & 1,176 & 1,984 & 465 & 540 \\
\hline National insurance scheme & 883 & 1,124 & 1,461 & 1,709 & 1,962 & 2,501 \\
\hline Taxes to the central government $1 /$ & 4,577 & 3,088 & 2,680 & 2,706 & 2,741 & 3,085 \\
\hline Dividends and transfers & 188 & 148 & 214 & 542 & 169 & 179 \\
\hline Interest & 127 & 43 & 200 & 185 & 46 & 82 \\
\hline Domestic & 0 & 0 & 0 & 63 & 46 & 82 \\
\hline External & 127 & 43 & 200 & 121 & 0 & 0 \\
\hline Current surplus or deficit (-) & 94 & $\mathbf{3 , 0 8 1}$ & 5,249 & 5,962 & 4,390 & 4,843 \\
\hline Capital expenditure & 3,071 & 1,107 & 2,082 & 3,227 & 2,637 & 3,009 \\
\hline Enterprises & 7,179 & 2,221 & 3,035 & 3,207 & 4,512 & 3,340 \\
\hline NIS & 47 & 21 & 58 & 21 & 59 & 39 \\
\hline Less government transfers & 4,155 & 1,136 & 1,011 & 0 & 1,934 & 370 \\
\hline Overall surplus or deficit $(-)$ & $-2,977$ & 1,975 & 3,167 & 2,735 & 1,753 & 1,834 \\
\hline Net foreign financing $2 /$ & 0 & 0 & 0 & 0 & 0 & 0 \\
\hline Net domestic financing & 2,977 & $-1,975$ & $-3,167$ & $-2,735$ & $-1,753$ & $\sim 1,834$ \\
\hline Banking system & -989 & 3,174 & 199 & $-1,036$ & $-1,049$ & -41 \\
\hline Central bank & $-1,568$ & 2,679 & -319 & 1,402 & 1,364 & 304 \\
\hline Commercial banks & 579 & 495 & 518 & $-2,438$ & $-2,413$ & -345 \\
\hline Other & 3,966 & $-5,149$ & $-3,366$ & $-1,699$ & -704 & $-1,793$ \\
\hline \multicolumn{7}{|l|}{ Of which } \\
\hline Debentures/treasury bills & -373 & $-1,055$ & $-1,595$ & $-1,765$ & 1,840 & $-2,623$ \\
\hline \multicolumn{7}{|c|}{ (In percent of GDP) } \\
\hline Revenue & 67.9 & 57.2 & 55.0 & 53.2 & 49.1 & 46.4 \\
\hline Current expenditure & 67.8 & 53.0 & 49.0 & 47.1 & 45.0 & 41.9 \\
\hline Noninterest expenditure & 67.5 & 53.0 & 48.8 & 46.9 & 44.9 & 41.8 \\
\hline Interest & 0.2 & 0.1 & 0.2 & 0.2 & 0.0 & 0.1 \\
\hline Current surplus or deficit $(-)$ & 0.2 & 4.1 & 6.0 & 6.0 & 4.1 & 4.5 \\
\hline Capital expenditure & 5.3 & 1.5 & 2.4 & 3.3 & 2.5 & 2.8 \\
\hline Overall surplus or deficit $(-)$ & -5.2 & 2.6 & 3.6 & 2.8 & 1.6 & 1.7 \\
\hline
\end{tabular}

Sources: Ministry of Finance; and Fund staff estimates.

1/ Taxes paid by enterprises.

2/ Amortization payments are consolidated with central government amortization repayments. 
Table 14. Guyana: Operations of the Public Corporations

(In millions of Guyana dollars)

\begin{tabular}{|c|c|c|c|c|c|c|}
\hline & 1993 & 1994 & 1995 & 1996 & 1997 & $\begin{array}{r}\text { Prel. } \\
1998 \\
\end{array}$ \\
\hline \multicolumn{7}{|c|}{ A GUYSUCO } \\
\hline Operating revenues & 16,190 & 18,067 & 20,583 & 23,756 & 22,202 & 21,506 \\
\hline Exports of sugar & 14,680 & 16,111 & 18,636 & 21,785 & 20,208 & 19,697 \\
\hline Local sales & 1,090 & 1,169 & 1,327 & 1,188 & 1,249 & 1,083 \\
\hline Other income & 420 & 787 & 620 & 783 & 745 & 726 \\
\hline Operating expenditure & 12,399 & 13,357 & 14,465 & 15,177 & 17,259 & 16,646 \\
\hline Wages and salaries & 5,613 & 6,910 & 7,133 & 7,507 & 10,146 & 8,835 \\
\hline Goods and services & 6,682 & 6,356 & 7,332 & 7,658 & 7,113 & 7,810 \\
\hline Foreign inputs & 2,720 & 3,012 & 3,781 & 0 & 0 & 0 \\
\hline Other local inputs & 3,962 & 3,344 & 3,551 & 7,658 & 7,113 & 7,810 \\
\hline Taxes, dividends, etc. & 0 & 0 & 0 & 0 & 0 & 0 \\
\hline Interest & 104 & 91 & 0 & 12 & 0 & 0 \\
\hline Domestic & -22 & 60 & 0 & 8 & 0 & 0 \\
\hline Foreign & 126 & 31 & 0 & 4 & 0 & 0 \\
\hline Sugar purchases & 0 & 0 & 0 & 0 & 0 & 0 \\
\hline Import duty--sugar & 0 & 0 & $\mathbf{0}$ & 0 & 0 & 0 \\
\hline Operating surplus or deficit (-) & 3,791 & 4,710 & 6,118 & 8,579 & 4,943 & 4,861 \\
\hline Transfers to the central government & 3,697 & 2,419 & 1,900 & 2,000 & 2,162 & 2,000 \\
\hline Taxes and levy & 3,697 & 2,419 & 1,900 & 2,000 & 2,162 & 2,000 \\
\hline Dividends & 0 & 0 & 0 & 0 & & 0 \\
\hline Current surplus or deficit (-) & 9 & 2,027 & 3,092 & 6,579 & 2,781 & 2,861 \\
\hline Capital expenditure & 1,811 & 822 & 2,000 & 1,604 & 2,643 & 2,514 \\
\hline Overall surplus or deficit $(-)$ & $-1,802$ & 1,205 & 1,092 & 4,975 & 138 & 347 \\
\hline \multicolumn{7}{|c|}{ B. GUYMINE (from 1994 represents the combined output of LINMINE and BERMINE) } \\
\hline Operating revenues & 8,368 & 6,061 & 6,176 & 5,585 & 6,144 & 5,867 \\
\hline Sales-export & 7,755 & 5,288 & 5,612 & 5,487 & 5,793 & 5,212 \\
\hline Other revenue & 613 & 773 & 564 & 398 & 350 & 655 \\
\hline Operating expenditure & 8,188 & 6,416 & 5,578 & 5,891 & 6,214 & 5,630 \\
\hline Wages and salaries & 1,367 & 1,318 & 1,303 & 1,466 & 1,581 & 1,559 \\
\hline Goods and services & 6,821 & 5,098 & 4,276 & 4,425 & 4,633 & 4,059 \\
\hline Interest & 0 & 0 & 0 & 0 & 12 & 11 \\
\hline Domestic & 0 & 0 & 0 & 0 & 12 & 11 \\
\hline External & 0 & 0 & 0 & 0 & 0 & 0 \\
\hline Operating surplus or deficit (-) & 180 & -355 & 597 & -6 & -70 & 237 \\
\hline Transfers to the central government & 89 & 5 & 30 & 0 & 0 & 0 \\
\hline Taxes & 89 & 5 & 30 & 0 & 0 & 0 \\
\hline Dividends & 0 & 0 & $\mathbf{0}$ & 0 & 0 & 0 \\
\hline Current surplus or deficit $(-)$ & 92 & -360 & 567 & -6 & -70 & 237 \\
\hline Capital expenditure & 2,768 & 644 & 209 & 106 & 82 & 663 \\
\hline Overall șurplus or deficit (-) & $-2,677$ & $-1,005$ & 358 & -112 & -152 & -426 \\
\hline
\end{tabular}


Table 14. Guyana: Operations of the Public Corporations

(In millions of Guyana dollars)

\begin{tabular}{|c|c|c|c|c|c|c|}
\hline & 1993 & 1994 & 1995 & 1996 & 1997 & $\begin{array}{r}\text { Prel. } \\
1998 \\
\end{array}$ \\
\hline \multicolumn{7}{|c|}{ B1. BERMINE } \\
\hline Operating revenues & $\ldots$ & 1,721 & 1,356 & 1,901 & 1,758 & 2,299 \\
\hline Sales-export & $\ldots$ & 1,437 & 1,197 & 1,690 & 1,576 & 2,027 \\
\hline Other revenue & $\ldots$ & 284 & 159 & 211 & 182 & 272 \\
\hline Operating expenditure & $\ldots$ & 1,549 & 1,232 & 1,933 & 1,710 & 1,972 \\
\hline Wages and salaries & $\ldots$ & 235 & 278 & 385 & 427 & 402 \\
\hline Goods and services & $\ldots$ & 1,315 & 954 & 1,548 & 1,283 & 1,570 \\
\hline Interest & $\ldots$ & 0 & 0 & 0 & 0 & 0 \\
\hline Domestic & $\ldots$ & 0 & 0 & 0 & 0 & 0 \\
\hline External & & 0 & 0 & 0 & 0 & 0 \\
\hline Operating surplus or deficit (-) & $\begin{array}{l}\ldots \\
\ldots\end{array}$ & 172 & 124 & -32 & 49 & 327 \\
\hline Transfers to the central government & $\begin{array}{l}\ldots \\
\ldots\end{array}$ & 0 & 0 & 0 & 0 & 0 \\
\hline Current surplus or deficit $(-)$ & $\ldots$ & 172 & 124 & -32 & 49 & 327 \\
\hline Capital expenditure & $\cdots$ & 145 & 51 & 11 & 14 & 256 \\
\hline Overall surplus or deficit (-) & $\ldots$ & 27 & 73 & -43 & 35 & 71 \\
\hline \multicolumn{7}{|c|}{ B2. LINMINE } \\
\hline Operating revenues & $\ldots$ & 4,340 & 4,820 & 3,984 & 4,386 & 3,568 \\
\hline Sales - export & ... & 3,851 & 4,415 & 3,798 & 4,217 & 3,186 \\
\hline Other revenue & ... & 489 & 404 & 186 & 169 & 383 \\
\hline Operating expenditure & $\ldots$ & 4,867 & 4,346 & 4,080 & 4,504 & 3,658 \\
\hline Wages and salaries & $\ldots$ & 1,083 & 1,025 & 1,082 & 1,154 & 1,157 \\
\hline Goods and services & $\ldots$ & 3,784 & 3,322 & 2,877 & 3,350 & 2,490 \\
\hline Interest & $\ldots$ & 0 & 0 & 121 & 12 & 11 \\
\hline Domestic & $\ldots$ & 0 & 0 & 9 & 12 & 11 \\
\hline External & $\ldots$ & 0 & 0 & 112 & 0 & 0 \\
\hline Operating surplus or deficit $(-)$ & $\ldots$ & -527 & 473 & -96 & -119 & -90 \\
\hline Transfers to the central government & $\ldots$ & 5 & 30 & 0 & 0 & 0 \\
\hline Taxes & $\ldots$ & 5 & 30 & 0 & 0 & 0 \\
\hline Dividends & $\ldots$ & 0 & 0 & 0 & 0 & 0 \\
\hline Current surplus or deficit $(-)$ & ... & -532 & 443 & -96 & -129 & -90 \\
\hline Capital expenditure & ... & 500 & 158 & 96 & 68 & 407 \\
\hline Overall surplus or deficit $(-)$ & $\cdots$ & $-1,032$ & 285 & -192 & -197 & -497 \\
\hline \multicolumn{7}{|c|}{ C. Guyana Electricity Corporation } \\
\hline Operating revenues & 1,969 & 2,745 & 3,035 & 3,873 & 4,586 & 4,462 \\
\hline Operating expenditure & 2,664 & 3,030 & 3,559 & 3,759 & 4,654 & 4,362 \\
\hline Wages and salaries & 409 & 492 & 578 & 623 & 714 & 853 \\
\hline Other & 2,255 & 2,538 & 2,981 & 3,136 & 3,940 & 3,509 \\
\hline
\end{tabular}


Table 14. Guyana: Operations of the Public Corporations

(In millions of Guyana dollars)

\begin{tabular}{|c|c|c|c|c|c|c|}
\hline & 1993 & 1994 & 1995 & 1996 & 1997 & $\begin{array}{r}\text { Prel. } \\
1998 \\
\end{array}$ \\
\hline \multicolumn{7}{|c|}{ C. Guyana Electricity Corporation } \\
\hline Operating surplus or deficit (-) & -695 & -285 & -524 & 114 & -68 & 100 \\
\hline Transfers to the central government & 0 & 0 & 0 & 0 & 0 & 0 \\
\hline Current surplus or deficit (-) & -695 & -294 & -524 & 114 & -68 & 100 \\
\hline Capital expenditure & 2,004 & 611 & 70 & 1,061 & 1,310 & 15 \\
\hline Overall surplus or deficit (-) & $-2,699$ & -905 & -594 & -947 & $-1,378$ & 85 \\
\hline \multicolumn{7}{|c|}{ D. Other Public Corporations } \\
\hline Operating revenues & 10,845 & 13,539 & 15,188 & 15,553 & 15,412 & 13,228 \\
\hline Operating expenditure & 9,629 & 11,755 & 13,115 & 14,539 & 14,976 & 12,992 \\
\hline Wages and salaries & 1,015 & 1,258 & 1,637 & 1,760 & 1,932 & 1,794 \\
\hline Goods and services & 8,992 & 10,998 & 12,228 & 12,734 & 13,011 & 11,168 \\
\hline Interest & -377 & -501 & -750 & 45 & 33 & 31 \\
\hline Domestic & -378 & -501 & .750 & 45 & 33 & 31 \\
\hline External & 0 & 0 & 0 & 0 & 0 & 0 \\
\hline Operating surplus or deficit (-) & 1,215 & 1,783 & 2,073 & 1,014 & 436 & 235 \\
\hline Transfers to the central government & 416 & 533 & 964 & 1,248 & 910 & 655 \\
\hline Taxes & 400 & 389 & 750 & 706 & 741 & 496 \\
\hline Dividends & 16 & 144 & 214 & 542 & 169 & 159 \\
\hline Special transfers & 0 & 0 & 0 & $\mathbf{0}$ & 0 & 0 \\
\hline Current surplus or deficit $(-)$ & 792 & 1,223 & 1,059 & -234 & -474 & -420 \\
\hline Capital expenditure & 596 & 144 & 135 & 260 & 482 & 148 \\
\hline Overall surplus or deficit (-) & 196 & 1,079 & 924 & -494 & -956 & -568 \\
\hline \multicolumn{7}{|c|}{ E. National Insurance Scheme } \\
\hline Income & 1,343 & 1,900 & 2,715 & 3,331 & 4,022 & 5,216 \\
\hline Contributions & 1,108 & 1,598 & 2,088 & 2,655 & 3,246 & 3,587 \\
\hline Investment income & 234 & 300 & 505 & 668 & 760 & 668 \\
\hline Other & 1 & 2 & 122 & 8 & 16 & 960 \\
\hline Expenditures & 883 & 1,124 & 1,461 & 1,708 & 1,962 & 2,501 \\
\hline Payment of benefits & 641 & 849 & 1,162 & 1,330 & 1,623 & 2,123 \\
\hline Other current expenditures & 242 & 275 & 298 & 378 & 339 & 379 \\
\hline Operating surplus or deficit (-) & 460 & 777 & 1,255 & 1,623 & 2,060 & 2,714 \\
\hline Capital expenditure & 47 & 21 & 58 & 21 & 59 & 40 \\
\hline Overall surplus or deficit $(-)$ & 413 & 755 & 1,197 & 1,602 & 2,001 & 2,675 \\
\hline
\end{tabular}

Sources: Ministry of Finance. 
Table 15. Guyana: Monetary Survey

\begin{tabular}{|c|c|c|c|c|c|c|}
\hline & 1993 & 1994 & 1995 & 1996 & 1997 & 1998 \\
\hline \multicolumn{7}{|c|}{ (In millions of Guyana dollars) } \\
\hline Net foreign assets & $-71,490$ & $-76,003$ & $-74,966$ & $-26,174$ & $-6,338$ & -62 \\
\hline Assets & 35,368 & 41,857 & 41,282 & 50,340 & 49,216 & 49,555 \\
\hline Liabilities & $-106,858$ & $-117,860$ & $-116,248$ & $-76,514$ & $-55,554$ & $-49,617$ \\
\hline Net domestic assets & 104,862 & 115,118 & 124,306 & $\mathbf{8 3 , 7 5 4}$ & 70,657 & 68,756 \\
\hline Public sector credit & $-4,707$ & $-11,328$ & $-10,967$ & $-19,248$ & $-17,277$ & $-12,715$ \\
\hline Central government (net) $1 /$ & 2,884 & $-6,912$ & $-6,750$ & $-13,994$ & 10,974 & $-6,372$ \\
\hline \multicolumn{7}{|l|}{ Other (public enterprises, } \\
\hline NIS and other agencies) & $-7,590$ & $-4,416$ & $-4,217$ & $-5,254$ & $-6,303$ & $-6,343$ \\
\hline Private sector credit & 10,230 & 13,799 & 21,107 & 36,309 & 44,863 & 51,838 \\
\hline Valuation adjustment & 55,789 & 63,553 & 62,931 & 62,013 & 63,535 & 63,953 \\
\hline Private capital and surplus & $-3,660$ & $-3,969$ & $-5,392$ & $-13,718$ & $-15,054$ & $-19,385$ \\
\hline \multicolumn{7}{|l|}{ Other items net (including } \\
\hline \multicolumn{7}{|l|}{ BOG capital, bank liabilities } \\
\hline to rest of financial sector) & 47,209 & 53,063 & 56,579 & 18,398 & $-5,411$ & $-14,934$ \\
\hline Liabilities to the private sector & 33,371 & 39,115 & 49,340 & $\mathbf{5 7 , 5 8 0}$ & 64,319 & 68,696 \\
\hline Monetary liabilities & 9,379 & 12,266 & 14,007 & 16,037 & 17,389 & 17,821 \\
\hline Currency in circulation & 6,480 & 8,167 & 8,967 & 9,959 & 11,193 & 11,334 \\
\hline Demand deposits & 2,899 & 4,099 & 5,040 & 6,078 & 6,169 & 6,486 \\
\hline Time and savings deposits & 23,992 & 26,849 & 35,333 & 41,543 & 46,931 & 50,875 \\
\hline \multicolumn{7}{|c|}{ (Change as a percent of broad money at beginning of period) } \\
\hline Net foreign assets & 6.1 & -13.5 & 2.7 & 98.9 & $\mathbf{3 4 . 5}$ & 9.8 \\
\hline Net domestic assets & 21.7 & 30.6 & 23.4 & -82.3 & -22.7 & -3.0 \\
\hline Public sector credit & -34.0 & -19.8 & 0.9 & -16.8 & 3.4 & 7.1 \\
\hline Private sector credit & 5.7 & 10.7 & 18.7 & 30.8 & 14.9 & 10.8 \\
\hline Other items net & 50.0 & 39.8 & 3.8 & -96.3 & -41.0 & -20.9 \\
\hline Broad money & 27.9 & 17.2 & 26.1 & 16.7 & $\mathbf{1 1 . 7}$ & 6.8 \\
\hline \multicolumn{7}{|l|}{ Velocity } \\
\hline Narrow money & 6.7 & 6.9 & 6.7 & 6.6 & 6.4 & 6.2 \\
\hline Broad money & 1.9 & 2.1 & 2.0 & 1.8 & 1.8 & 1.6 \\
\hline
\end{tabular}

Source: Bank of Guyana.

1/ Excludes interest-free debentures issued to the Bank of Guyana to cover losses. 
Table 16. Guyana: Accounts of the Bank of Guyana

(In millions of Guyana dollars)

\begin{tabular}{|c|c|c|c|c|c|c|}
\hline & 1993 & 1994 & 1995 & 1996 & 1997 & 1998 \\
\hline Net foreign assets & $-72,599$ & $-76,618$ & $-75,881$ & $-26,357$ & $-4,872$ & 1,239 \\
\hline Assets & 32,178 & 38,309 & 37,484 & 46,590 & 45,719 & 45,675 \\
\hline Liabilities & $-104,777$ & $-114,927$ & $-113,365$ & $-72,947$ & $-50,591$ & $-44,436$ \\
\hline Net domestic assets & 79,080 & $\mathbf{8 4 , 7 8 5}$ & 84,848 & 36,317 & 16,065 & 10,095 \\
\hline Public sector (net) & $-18,835$ & $-21,164$ & $-21,564$ & $-29,183$ & $-25,894$ & $-19,436$ \\
\hline Central government $1 /$ & $-14,511$ & $-19,520$ & $-19,601$ & $-28,622$ & $-26,697$ & $-20,542$ \\
\hline Treasury bills & 688 & 2,363 & 340 & 795 & 238 & 1,020 \\
\hline Debentures & 175 & 174 & 174 & 0 & 0 & 0 \\
\hline Deposits & $-15,374$ & $-22,058$ & $-20,115$ & $-29,417$ & $-26,935$ & $-21,563$ \\
\hline Special funds & -7 & -7 & -7 & -7 & .7 & -7 \\
\hline \multicolumn{7}{|l|}{ Social security, pensions, and } \\
\hline other public sector & $-4,317$ & $-1,638$ & $-1,913$ & -544 & 809 & 1,113 \\
\hline Liabilities to commercial banks & 5,326 & 7,899 & 10,202 & 10,794 & 13,097 & 15,839 \\
\hline Currency & 461 & 591 & 640 & 1,343 & 1,277 & 1,184 \\
\hline Bankers' deposits & 4,498 & 6,973 & 9,232 & 9,121 & 11,502 & 14,345 \\
\hline Deposits on external payments arrears & 368 & 335 & 331 & 330 & 318 & 310 \\
\hline Other items net & 103,240 & 113,847 & 116,614 & 76,293 & 55,056 & 45,370 \\
\hline Valuation adjustment & 57,471 & 65,235 & 64,613 & 63,695 & 65,217 & 65,635 \\
\hline Capital, reserves and counterpart items & 45,769 & 48,612 & 52,001 & 12,598 & $-10,161$ & $-20,265$ \\
\hline Capital and contigency reserves & $-50,618$ & $-59,179$ & $-58,045$ & $-58,023$ & $-57,952$ & $-59,796$ \\
\hline \multicolumn{7}{|l|}{ Medium-term liabilities and } \\
\hline nonmonetary external deposits & $-1,063$ & $-1,151$ & -580 & -488 & -457 & -516 \\
\hline Unclassified assets and liabilities (net) & 116,787 & 128,653 & 136,707 & 95,429 & 75,514 & 68,380 \\
\hline $\begin{array}{l}\text { Assets } \\
\text { Of which }\end{array}$ & 117,594 & 129,291 & 137,639 & 96,660 & 76,758 & 69,748 \\
\hline \multicolumn{7}{|l|}{ Of which } \\
\hline Noninterest debentures & 116,805 & 124,134 & 134,849 & 94,849 & 75,044 & 67,961 \\
\hline Counterpart liabilities & 175 & 220 & 484 & 222 & 224 & 0 \\
\hline Liabilities & -807 & -638 & -932 & $-1,231$ & $-1,244$ & $-1,368$ \\
\hline Counterpart unrequited foreign exchange & $-19,337$ & $-19,711$ & $-26,081$ & $-24,319$ & $-27,266$ & $-28,333$ \\
\hline SDR allocation account & 2,609 & 3,023 & 3,035 & 2,951 & 2,823 & 3,381 \\
\hline \multicolumn{7}{|l|}{ Other counterpart entries including } \\
\hline \multicolumn{7}{|l|}{ Of which } \\
\hline \multicolumn{7}{|l|}{ Valuation adjustment and } \\
\hline fund account & $-7,750$ & $-8,828$ & $-2,276$ & $-2,369$ & $-1,031$ & -966.1 \\
\hline Currency in circulation & 6,480 & 8,167 & 8,967 & 9,959 & 11,193 & 11,334 \\
\hline Currency issue & 6,941 & 8,758 & 9,607 & 11,303 & 12,470 & 12,518 \\
\hline Less holdings of commercial banks & -461 & -591 & -640 & $-1,343$ & $-1,277$ & $-1,183$ \\
\hline
\end{tabular}

Source: Bank of Guyana.

1/ Excludes interest-free debentures issued to the Bank of Guyana to cover losses. 
Table 17. Guyana: Accounts of the Commercial Banks

(In millions of Guyana dollars)

\begin{tabular}{|c|c|c|c|c|c|c|}
\hline & 1993 & 1994 & 1995 & 1996 & 1997 & 1998 \\
\hline Net foreign assets & 1,109 & 615 & 915 & 183 & $-1,466$ & $-1,301$ \\
\hline Assets & 3190 & 3,548 & 3798 & 3,750 & 3,498 & 3880 \\
\hline Liabilities & $-2,081$ & $-2,933$ & $-2,883$ & $-3,567$ & $-4,963$ & $-5,181$ \\
\hline Net domestic assets & 25,782 & $\mathbf{3 0 , 3 3 3}$ & 39,457 & 47,438 & $\mathbf{5 4 , 5 9 2}$ & 58,662 \\
\hline Credit to public sector & 14,128 & 9,836 & 10597 & 9,935 & 8,617 & $6,720.60$ \\
\hline Central government & 17,395 & 12,608 & 12851 & 14,627 & 15,723 & $14,170.60$ \\
\hline \multicolumn{7}{|l|}{ Credit (treasury bills and } \\
\hline debentures) & 20,027 & 15,615 & 14,806 & 17,222 & 18,027 & 15,850 \\
\hline Advances & 37 & 33 & 33 & 28 & 1 & 1 \\
\hline Deposits & $-2,669$ & $-3,042$ & $-1,996$ & $-2,623$ & $-2,303$ & $-1,680$ \\
\hline \multicolumn{7}{|l|}{ Public enterprises, NIS and other } \\
\hline agencies & $-3,267$ & $-2,772$ & $-2,086$ & $-4,692$ & $-7,105$ & $-7,450$ \\
\hline NIS and other agencies & -504 & -262 & -168 & .404 & $-3,487$ & $-3,850$ \\
\hline Public enterprises & $-2,763$ & $-2,510$ & $-1,918$ & $-4,288$ & $-3,618$ & $-3,601$ \\
\hline Credit & 470.6 & 188 & 409.7 & 255 & 216 & 410.2 \\
\hline Deposits & $-3,234$ & $-2,698$ & $-2,327$ & $-4,542$ & $-3,835$ & $-4,011$ \\
\hline Credit to private sector & 10,230 & 13,799 & 21,107 & 36,309 & 44,863 & 51,838 \\
\hline Other & 1,424 & 6,698 & 7,753 & 1,194 & 1,111 & 104 \\
\hline Private capital and surplus & $-3,660$ & $-3,969$ & $-5,392$ & $-13,718$ & $-15,054$ & $-19,385$ \\
\hline Interbank float & 106 & 382 & 756 & 755 & 1,081 & 487 \\
\hline Claims on BOG (net) & 5,563 & 8,232 & 10,387 & 10,790 & 13,376 & 16,132 \\
\hline Currency & 461 & 591 & 640 & 1,343 & 1,277 & 1,184 \\
\hline Deposits & 4,735 & 7,306 & 9,417 & 9,117 & 11,782 & 14,637 \\
\hline EPD deposits & 367 & 334 & 331 & 330 & 318 & 310 \\
\hline Valuation adjustment & $-1,682$ & $-1,682$ & $-1,682$ & $-1,682$ & $-1,682$ & $-1,682$ \\
\hline Other items (net) & 1,097 & 3,736 & 3,683 & 5,049 & 3,390 & 4,552 \\
\hline \multicolumn{7}{|l|}{ Of which } \\
\hline \multicolumn{7}{|l|}{ Liabilities to rest of the } \\
\hline financial system & 2,875 & 1,342 & 1,891 & 2,574 & 3,660 & 5,703 \\
\hline \multicolumn{7}{|l|}{ External payment deposits } \\
\hline (EPDs) & 368 & 335 & 331 & 330 & 318 & 310 \\
\hline Liabilities to private sector & 26,891 & 30,948 & 40,372 & 47,621 & 53,127 & $\mathbf{5 7 , 3 6 1}$ \\
\hline Monetary liabilities & 2,899 & 4,099 & 5,040 & 6,078 & 6,196 & 6,486 \\
\hline Demand deposits & 2,405 & 3,516 & 4,301 & 5,131 & 5,186 & 5,547 \\
\hline Cashiers and managers checks & 494 & 583 & 738 & 947 & 1,010 & 939 \\
\hline Time and savings deposits & 23,992 & 26,849 & 35,333 & 41,543 & 46,931 & 50,875 \\
\hline
\end{tabular}

Source: Bank of Guyana. 
Table 18. Guyana: Net Foreign Assets of the Banking System

(In millions of U.S. dollars)

\begin{tabular}{lrrrrrr}
\hline & 1993 & 1994 & 1995 & 1996 & 1997 & 1998 \\
\hline Net foreign assets & $-\mathbf{5 4 7}$ & $-\mathbf{5 3 4}$ & $\mathbf{- 5 3 4}$ & $\mathbf{- 1 8 6}$ & $\mathbf{- 4 4}$ & $\mathbf{6}$ \\
& & & & & & \\
Bank of Guyana & -555 & -538 & -540 & -187 & -34 & 14 \\
Gross international reserves & 246 & 269 & 269 & $\mathbf{3 3 2}$ & $\mathbf{3 1 5}$ & 276 \\
Short-term liabilities & -190 & -190 & -182 & -178 & -165 & -148 \\
$\quad$ Current & -185 & -185 & -176 & -171 & -159 & -148 \\
$\quad$ Venezuela Investment Fund & -8 & -6 & -4 & -3 & -2 & 0 \\
$\quad$ Use of fund credit & -177 & -179 & -172 & -168 & -157 & -148 \\
$\quad$ In arrears & -5 & -6 & -6 & -7 & -7 & 0 \\
Medium-term liabilities & -7 & -7 & -3 & -3 & -3 & -3 \\
Rescheduled liabilities & -604 & -610 & -623 & $-\mathbf{3 3 8}$ & -181 & -112 \\
& & & & & -10 & -8 \\
Commercial banks & 9 & 4 & 7 & 1 & -10 \\
\hline
\end{tabular}

Source: Bank of Guyana. 
Table 19. Guyana: Commercial Bank Credit by Sector

\begin{tabular}{|c|c|c|c|c|c|c|}
\hline & 1993 & 1994 & 1995 & 1996 & 1997 & 1998 \\
\hline \multicolumn{7}{|c|}{ (In millions of Guyana dollars) } \\
\hline Tatal & 10,700 & 13,987 & 21,517 & 36,593 & 45,079 & 52,248 \\
\hline Credit to private sector & 10,230 & 13,799 & 21,107 & 36,309 & 44,863 & 51,838 \\
\hline Agriculture & 1,074 & 1,729 & 3,290 & 7,950 & 7,266 & 8,978 \\
\hline Sugarcane & 32 & 65 & 26 & 33 & 186 & 181 \\
\hline Rice Paddy & 437 & 963 & 2,263 & 6,705 & 4,311 & 6,140 \\
\hline Other & 606 & 701 & 1,000 & 1,212 & 2,769 & 2,657 \\
\hline Mining & 602 & 644 & 839 & 1,016 & 918 & 1,042 \\
\hline Timber and sawmilling & 589 & 608 & 570 & 938 & 1,834 & 1,967 \\
\hline Construction & 511 & 439 & 554 & 1,163 & 1,769 & 2,198 \\
\hline Manufacturing & 2,412 & 1,358 & 2,071 & 8,314 & 9,040 & 13,750 \\
\hline Transport and communications & 344 & 362 & 634 & 689 & 950 & 943 \\
\hline Distribution & 2,044 & 3,248 & 4,713 & 7,026 & 7,637 & 8,715 \\
\hline Housing and real estate & 410 & 722 & 1,377 & 2,125 & 2,469 & 2,943 \\
\hline Personal (excluding housing) & 1,680 & 2,410 & 3,908 & 3,984 & 6,299 & 7,004 \\
\hline Cooperatives & 26 & 36 & 38 & 38 & 162 & 147 \\
\hline \multicolumn{7}{|l|}{$\begin{array}{l}\text { Services and other (including } \\
\text { mortgage and other local }\end{array}$} \\
\hline security loans) & 539 & 2,243 & 3,113 & 3,066 & 6,520 & 4,151 \\
\hline Credit to public enterprises & 471 & 188 & 410 & 284 & 216 & 410 \\
\hline Sugar & 0 & 0 & 121 & 0 & 0 & 0 \\
\hline Bauxite & 0 & 110 & 228 & 148 & 49 & 177 \\
\hline Timber and sawmilling & 0 & 0 & 0 & 0 & 0 & 0 \\
\hline Transport and communications & 0 & 0 & 0 & 0 & 0 & 39 \\
\hline Distribution (including rice) & 31 & 3 & 0 & 83 & 73 & 80 \\
\hline Other & 440 & 75 & 61 & 53 & 95 & 115 \\
\hline \multicolumn{7}{|c|}{ (In percent of total) } \\
\hline Private sector & 95.6 & 98.7 & 98.1 & 99.2 & 99.5 & 99.2 \\
\hline Public sector & 4.4 & 1.3 & 1.9 & 0.8 & 0.5 & 0.8 \\
\hline \multicolumn{7}{|c|}{ (Annual percentage change) } \\
\hline Total & 11.8 & 30.7 & 53.8 & 70.1 & 23.2 & 15.9 \\
\hline Private sector & 17.1 & 34.9 & 53.0 & 72.0 & 23.6 & 15.5 \\
\hline Public sector & -43.6 & -60.1 & 118.1 & -30.7 & -23.9 & 89.8 \\
\hline
\end{tabular}

Source: Bank of Guyana. 
Table 20. Guyana: Liabilities of the Banking System to the Private Sector

\begin{tabular}{|c|c|c|c|c|c|c|}
\hline & 1993 & 1994 & 1995 & 1996 & 1997 & 1998 \\
\hline \multicolumn{7}{|c|}{ (In millions of Guyana dollars) } \\
\hline Total & 33,371 & 39,115 & 49,340 & $\mathbf{5 7 , 5 8 0}$ & 64,319 & 68,696 \\
\hline Monetary liabilities & 9,379 & 12,266 & 14,007 & 16,037 & 17,389 & 17,821 \\
\hline Currency in circulation & 6,480 & 8,167 & 8,967 & 9,959 & 11,193 & 11,334 \\
\hline Demand deposits & 2,899 & 4,099 & 5,040 & 6,078 & 6,196 & 6,486 \\
\hline Time and savings deposits & 23,992 & 26,849 & 35,333 & 41,543 & 46,931 & 50,875 \\
\hline \multicolumn{7}{|c|}{ (Annual percentage change) } \\
\hline Total & 28.0 & 17.0 & 26.0 & 17.0 & 11.7 & 6.8 \\
\hline Monetary liabilities & 21.0 & 31.0 & 14.0 & 14.0 & 8.4 & 2.5 \\
\hline Currency in circulation & 27.0 & 26.0 & 10.0 & 11.0 & 12.4 & 1.3 \\
\hline Demand deposits & 10.0 & 41.0 & 23.0 & 21.0 & 1.9 & 4.7 \\
\hline Time and savings deposits & 31.0 & 12.0 & 32.0 & 18.0 & 13.0 & 8.4 \\
\hline \multicolumn{7}{|c|}{ (In percent of GDP) } \\
\hline Total & 58.0 & 52.3 & 56.0 & 58.4 & 60.3 & 63.3 \\
\hline Monetary liabilities & 16.3 & 16.4 & 15.9 & 16.3 & 16.3 & 16.4 \\
\hline Currency in circulation & 11.3 & 10.9 & 10.2 & 10.1 & 10.5 & 10.4 \\
\hline Demand deposits & 5.0 & 5.5 & 5.7 & 6.2 & 5.8 & 6.0 \\
\hline Time and savings deposits & 41.7 & 35.9 & 40.1 & 42.1 & 44.0 & 46.9 \\
\hline \multicolumn{7}{|l|}{ Memorandum item: } \\
\hline \multicolumn{7}{|l|}{ GDP at market prices } \\
\hline (G\$ billion) & 57.6 & 74.8 & 88.1 & 98.6 & 106.7 & 108.5 \\
\hline
\end{tabular}

Source: Bank of Guyana. 
Table 21. Guyana: Commercial Banks Liquid Asset Requirements

\begin{tabular}{|c|c|c|c|c|c|c|}
\hline & 1993 & 1994 & 1995 & 1996 & 1997 & 1998 \\
\hline \multicolumn{7}{|c|}{ (In millions of Guyana dollars) } \\
\hline Liabilities & 38,362 & 41,713 & 50,823 & 63,101 & 72,150 & 64,663 \\
\hline Demand deposits & 6,467 & 7,596 & 10,207 & 11,984 & 11,643 & 10,808 \\
\hline Time and savings deposits & 31,895 & 34,117 & 40,616 & 51,117 & 60,507 & 53,855 \\
\hline \multicolumn{7}{|l|}{ Liquid assets } \\
\hline Required & 7,996 & 8,667 & 10,673 & 13,219 & 15,012 & 13,473 \\
\hline Actual & 23,198 & 21,184 & 21,453 & 21,476 & 25,588 & 24,808 \\
\hline Foreign assets & 2,355 & 2,590 & 2,582 & 2,209 & 3,627 & 2,479 \\
\hline Currency & 612 & 679 & 761 & 1,435 & 1,342 & 1,557 \\
\hline Reserve deposits & 4,524 & 7,265 & 9,168 & 9,429 & 11,465 & 15,376 \\
\hline Treasury bills & 15,580 & 10,059 & 8,195 & 7,770 & 8,798 & 4,776 \\
\hline Other & 128 & 591 & 747 & 633 & 356 & 620 \\
\hline Excess & 15,202 & 12,517 & 10,780 & 8,257 & 10,576 & 11,335 \\
\hline \multicolumn{7}{|c|}{ (In percent of total liabilities) } \\
\hline \multicolumn{7}{|l|}{ Reserves } \\
\hline Required & 20.8 & 20.8 & 21.0 & 20.0 & 20.8 & 20.8 \\
\hline Actual & 60.5 & 50.8 & 42.2 & 34.0 & 35.5 & 38.4 \\
\hline Excess & 39.6 & 30.0 & 21.2 & 14.0 & 14.7 & 17.5 \\
\hline Actual/required & 2.9 & 2.4 & 2.0 & 1.7 & 1.7 & 1.8 \\
\hline
\end{tabular}

Source: Bank of Guyana. 
Table 22. Guyana: Reserve Requirements of the Commercial Banks

\begin{tabular}{|c|c|c|c|c|c|c|}
\hline & 1993 & 1994 & 1995 & 1996 & 1997 & 1998 \\
\hline \multicolumn{7}{|c|}{ (Average for the last reserve period, in millions of Guyana dollars) } \\
\hline Liabilities & 38,362 & 41,713 & $\mathbf{5 0 , 8 2 3}$ & 63,101 & 71,414 & 76,936 \\
\hline Demand deposits & 6,467 & 7,596 & 10,207 & 11,984 & 10,993 & 10,456 \\
\hline Time deposits & 31,895 & 34,117 & 40,616 & 51,117 & 60,421 & 66,479 \\
\hline \multicolumn{7}{|l|}{ Reserves } \\
\hline Required & 3,583 & 5,836 & 7,209 & 8,802 & 10,286 & 10,980 \\
\hline Actual & 3,896 & 5,899 & 8,872 & 11,848 & $13 ; 093$ & 14,358 \\
\hline Excess & 313 & 63 & 1,663 & 3,046 & 2,807 & 3,379 \\
\hline \multicolumn{7}{|c|}{ (In percent of total liabilities) } \\
\hline \multicolumn{7}{|l|}{ Reserves } \\
\hline Required & 9.3 & 14.0 & 14.2 & 13.9 & 14.4 & 14.3 \\
\hline Actual & 10.2 & 14.1 & 17.5 & 18.7 & 18.3 & 18.7 \\
\hline Excess & 0.8 & 0.2 & 3.3 & 4.8 & 3.9 & 4.4 \\
\hline Actual/required & 1.1 & 1.0 & 1.2 & 1.4 & 1.3 & 1.3 \\
\hline
\end{tabular}

Source: Bank of Guyana. 
Table 23. Guyana: Private Sector Holdings of Domestic Financial Assets

\begin{tabular}{|c|c|c|c|c|c|c|}
\hline & 1993 & 1994 & 1995 & 1996 & 1997 & 1998 \\
\hline \multicolumn{7}{|c|}{ (In millions of Guyana dollars) } \\
\hline Total & 44,002 & 53,747 & 65,898 & 75,875 & $\mathbf{8 4 , 2 6 9}$ & 91,708 \\
\hline \multicolumn{7}{|l|}{ By asset type } \\
\hline Claims on financial system & 42,314 & 49,208 & 61,892 & 72,837 & 83,151 & 91,210 \\
\hline Banking system & 32,937 & 38,533 & 48,602 & 56,634 & 63,310 & 67,757 \\
\hline Currency in circulation & 6,480 & 8,167 & 8,967 & 9,959 & 11,193 & 11,334 \\
\hline Demand deposits & 2,465 & 3,516 & 4,301 & 5,131 & 5,186 & 5,547 \\
\hline Time deposits & 8,596 & 8,780 & 12,756 & 15,443 & 16,833 & 17,048 \\
\hline Savings deposits & 15,396 & 18,069 & 22,577 & 26,100 & 30,098 & 33,828 \\
\hline Nonbanks & 9,376 & 10,676 & 13,291 & 16,203 & 19,841 & 23,453 \\
\hline Deposits & 4,501 & 5,525 & 6,920 & 8,663 & 10,549 & 12,162 \\
\hline Shares & 3,004 & 3,758 & 4,767 & 6,440 & 7,871 & 9,130 \\
\hline Other & 1,498 & 1,767 & 2,153 & 2,223 & 2,678 & 3,032 \\
\hline Insurance premia & 2,025 & 1,440 & 1,660 & 1,891 & 1,962 & 2,174 \\
\hline Pension Fund & 2,659 & 3,550 & 4,524 & 5,382 & 6,371 & 7,651 \\
\hline Trust Fund & 192 & 162 & 188 & 267 & 959 & 1,466 \\
\hline Claims on the central government & 1,689 & 4,538 & 4,006 & 3,038 & 1,118 & 498 \\
\hline Treasury bills & 1,589 & 3,010 & 2,508 & 2,637 & 783 & 80 \\
\hline Government debentures & 74 & 1,501 & 1,470 & 385 & 326 & 412 \\
\hline Defense bonds & 25 & 28 & 28 & 17 & 9 & 6 \\
\hline \multicolumn{7}{|l|}{ By institution } \\
\hline Financial intermediaries & 42,314 & 49,208 & 61,892 & 72,836 & 83,151 & 91,210 \\
\hline Bank of Guyana & 6,480 & 8,167 & 8,967 & 9,959 & 11,193 & 11,334 \\
\hline Commercial banks & 26,457 & 30,366 & 39,634 & 46,674 & 52,117 & 56,422 \\
\hline Nonbanks & 9,376 & 10,676 & 13,291 & 16,203 & 19,841 & 23,110 \\
\hline Building Society & 3,192 & 3,988 & 5,006 & 6,700 & 8,157 & 9,469 \\
\hline Trust companies & 1,501 & 1,698 & 2,101 & 2,230 & 3,351 & 4,159 \\
\hline Insurance companies & 2,025 & 1,440 & 1,660 & 1,891 & 1,962 & 2,174 \\
\hline Pension schemes & 2,659 & 3,550 & 4,524 & 5,382 & 6,371 & 7,651 \\
\hline Central government & 1,689 & 4,538 & 4,006 & 3,038 & 1,118 & 498 \\
\hline \multicolumn{7}{|c|}{ (In percent of total) } \\
\hline \multicolumn{7}{|l|}{ By asset type } \\
\hline Claims on financial system & 96.2 & 91.6 & 93.9 & 96.0 & 98.7 & 99.5 \\
\hline Banking system & 74.9 & 71.7 & 73.8 & 74.6 & 75.1 & 73.9 \\
\hline Currency in circulation & 14.7 & 15.2 & 13.6 & 13.1 & 13.3 & 12.4 \\
\hline Demand deposits & 5.6 & 6.5 & 6.5 & 6.8 & 6.2 & 6.0 \\
\hline Time and saving deposits & 54.5 & 50.0 & 53.6 & 54.8 & 55.7 & 55.5 \\
\hline Nonbanks & 21.3 & 19.9 & 20.2 & 21.4 & 23.5 & 25.6 \\
\hline Claims on the central government & 3.8 & 8.4 & 6.1 & 4.0 & 1.3 & 0.5 \\
\hline Treasury bills & 3.6 & 5.6 & 3.8 & 3.5 & 0.9 & 0.1 \\
\hline Government debentures & 0.2 & 2.8 & 2.2 & 0.5 & 0.4 & 0.4 \\
\hline Defense bonds & 0.1 & 0.1 & 0.0 & 0.0 & 0.0 & -0.0 \\
\hline \multicolumn{7}{|l|}{ By institution } \\
\hline Financial intermediaries & 96.2 & 91.6 & 93.9 & 96.0 & 98.7 & 99.5 \\
\hline Bank of Guyana & 14.7 & 15.2 & 13.6 & 13.1 & 13.3 & 12.4 \\
\hline Commercial banks & 60.1 & 56.5 & 60.1 & 61.5 & 61.8 & 61.5 \\
\hline Nonbanks & 21.3 & 19.9 & 20.2 & 21.4 & 23.5 & 25.2 \\
\hline Central government & 3.8 & 8.4 & 6.1 & 4.0 & 1.3 & 0.5 \\
\hline \multicolumn{7}{|l|}{ Memorandum items: } \\
\hline Total assets (percent of GDP) & 76.4 & 71.9 & 74.8 & 77.0 & 79.0 & 79.0 \\
\hline Total assets (percent change) & 25.2 & 22.1 & 22.6 & 15.1 & 11.1 & 8.8 \\
\hline
\end{tabular}

Source: Bank of Guyana. 
Table 24. Guyana: Private Nonbank Financial Institutions

(In millions of Guyana dollars)

\begin{tabular}{|c|c|c|c|c|c|c|}
\hline & 1993 & 1994 & 1995 & 1996 & 1997 & 1998 \\
\hline Net foreign assets & 40 & -35 & 588 & 1,214 & 1,619 & 1,857 \\
\hline Assets & 3,206 & 3,949 & 4,537 & 4,646 & 5,241 & 5,786 \\
\hline Liabilities & $-3,165$ & $-3,984$ & $-3,950$ & $-3,432$ & $-3,622$ & $-3,929$ \\
\hline Claims on other financial institutio & 667 & 879 & $2, \mathbf{2 3 0}$ & 4,152 & 5,343 & 6,491 \\
\hline Net domestic assets & 11,076 & 13,231 & 17,288 & 16,590 & 15,920 & 17,637 \\
\hline Central government & 3,846 & 6,221 & 6,886 & 6,599 & 6,138 & 6,128 \\
\hline Treasury bills & 3,241 & 5,683 & 6,408 & 6,215 & 5,689 & 5,753 \\
\hline Debentures & 605 & 538 & 478 & 384 & 449 & 375 \\
\hline Rest of public sector & 11 & 117 & 10 & 0 & 0 & 132 \\
\hline Private sector & 1,441 & 4,770 & 7,385 & 9,458 & 13,235 & 16,108 \\
\hline Unclassified (net) & 5,778 & 2,122 & 3,007 & 533 & $-3,452$ & $-4,731$ \\
\hline Liabillties to private sector & 11,783 & 14,074 & 20,105 & 21,955 & 22,882 & 25,984 \\
\hline
\end{tabular}

Source: Bank of Guyana. 
Table 25. Guyana: Selected Interest Rates

(In percent per annum)

\begin{tabular}{|c|c|c|c|c|c|c|}
\hline & 1993 & 1994 & 1995 & 1996 & 1997 & 1998 \\
\hline \multicolumn{7}{|l|}{ Local rates } \\
\hline Prime lending rate & 17.5 & 19.9 & 19.1 & 17.2 & 16.9 & 17.0 \\
\hline Bank rate & 17.0 & 26.3 & 17.3 & 12.0 & 11.0 & 11.3 \\
\hline Treasury bills (91-day) & 15.4 & 18.6 & 15.5 & 9.9 & 8.2 & 8.8 \\
\hline Small savings rate & 9.5 & 11.2 & 10.5 & 7.7 & 7.4 & 7.1 \\
\hline \multicolumn{7}{|l|}{ Time deposits } \\
\hline 3-month & 10.9 & 12.8 & 12.8 & 9.0 & 8.4 & 8.0 \\
\hline 6-month & 11.8 & 14.4 & 13.8 & 9.9 & 9.4 & 8.3 \\
\hline 12-month & 12.3 & 14.3 & 14.4 & 9.5 & 9.3 & 9.7 \\
\hline \multicolumn{7}{|l|}{$\begin{array}{l}\text { Interest paid on deposits against } \\
\text { external payment arrears }\end{array}$} \\
\hline with commercial banks & 18.2 & 20.8 & 20.4 & 110.0 & 9.8 & 10.0 \\
\hline Weighted average time deposit rate & 11.0 & 13.0 & 13.0 & 9.6 & 8.5 & 8.2 \\
\hline Weighted average lending rate & 18.2 & 20.8 & 20.4 & 18.5 & 18.3 & 18.4 \\
\hline \multicolumn{7}{|l|}{ International rates } \\
\hline LIBOR & 3.3 & 4.7 & 6.0 & 5.5 & 5.8 & 5.6 \\
\hline \multicolumn{7}{|l|}{ Treasury bill rate } \\
\hline United Kingdom & 5.2 & 5.2 & 6.4 & 5.8 & 6.5 & 6.8 \\
\hline United States & 3.0 & 4.3 & 5.5 & 5.0 & 5.1 & 4.8 \\
\hline Canada & 4.8 & 5.5 & 6.9 & 4.2 & 3.3 & 4.7 \\
\hline Jamaica & 28.9 & 43.0 & 27.7 & 38.0 & 21.1 & 25.7 \\
\hline Trinidad & 9.5 & 10.0 & 8.4 & 10.4 & 9.8 & 11.9 \\
\hline
\end{tabular}

Sources: IMF, International Financial Statistics; data provided by the Guyanese authorities; and Fund staff estimates. 
Table 26. Guyana: Balance of Payments

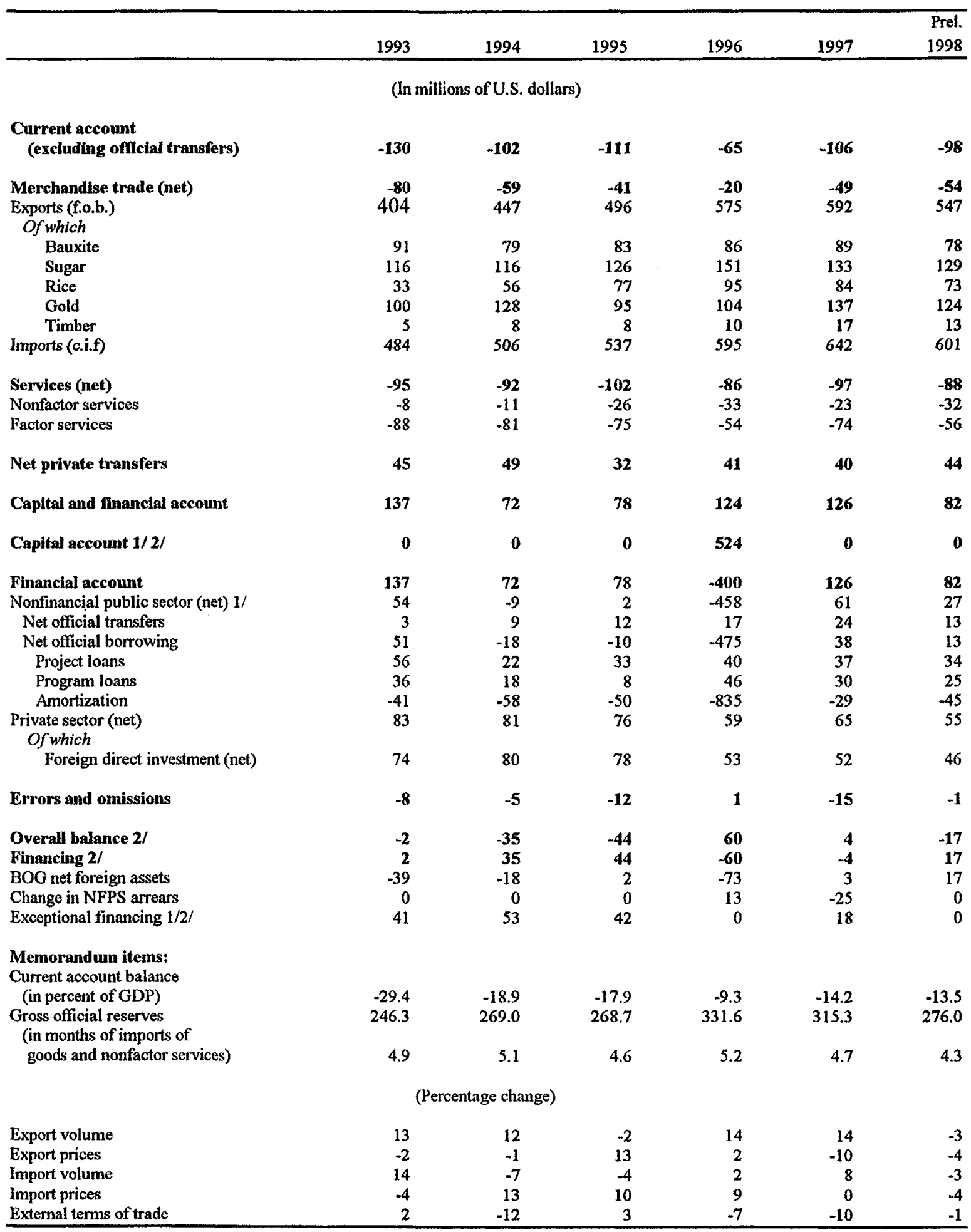

Sources: Bank of Guyana; Statistical Bureau of Guyana; Ministry of Finance, and Fund staff estimates and projections.

1/ In 1996 Guyana received a debt-stock reduction on Naples terms from Paris Club Creditors, including Trinidad and Tobago. For 1999 comparable treatment from Non-Paris Club bilateral creditors is assumed.

$2 /$ Debt forgiveness of future maturities is presented as a capital transfer and debt forgiveness of arrears and current maturities is captured under exceptional financing. 
Table 27. Guyana: Value, Price, and Volume Indices for Exports and Imports

\begin{tabular}{|c|c|c|c|c|c|c|}
\hline & 1993 & 1994 & 1995 & 1996 & 1997 & $\begin{array}{l}\text { Prel. } \\
1998 \\
\end{array}$ \\
\hline \multicolumn{7}{|c|}{$(1982=100)$} \\
\hline \multicolumn{7}{|l|}{ Exports } \\
\hline Value & 141.6 & 156.8 & 173.7 & 201.6 & 207.6 & 191.9 \\
\hline Prices & 100.9 & 99.5 & 112.2 & 114.1 & 103.2 & 98.7 \\
\hline Volume & 140.3 & 157.5 & 154.8 & 176.7 & 201.1 & 194.4 \\
\hline \multicolumn{7}{|l|}{ Imports } \\
\hline Value & 138.5 & 144.9 & 153.7 & 170.3 & 183.7 & 172.1 \\
\hline Prices & 113.4 & 127.8 & 140.5 & 153.4 & 153.6 & 148.1 \\
\hline Volume & 122.1 & 113.4 & 109.3 & 111.0 & 119.5 & 116.2 \\
\hline Terms of trade & 89.0 & 77.9 & 79.9 & 74.4 & 67.2 & 66.6 \\
\hline \multicolumn{7}{|c|}{ (Annual changes in percent) } \\
\hline \multicolumn{7}{|l|}{ Exports } \\
\hline Value & 11.1 & 10.7 & 10.8 & 16.1 & 2.9 & -7.6 \\
\hline Unit Value & -2.0 & -1.4 & 12.8 & 1.7 & -9.5 & -4.4 \\
\hline Volume & 13.4 & 12.3 & -1.7 & 14.2 & 13.8 & -3.3 \\
\hline \multicolumn{7}{|l|}{ Imports } \\
\hline Value & 9.3 & 4.7 & 6.0 & 10.8 & 7.8 & -6.3 \\
\hline Unit Value & -3.9 & 12.7 & 10.0 & 9.1 & 0.2 & -3.6 \\
\hline Volume & 13.7 & -7.1 & -3.6 & 1.6 & 7.7 & -2.8 \\
\hline Terms of trade & 2.0 & -12.4 & 2.5 & -6.8 & -9.7 & -0.8 \\
\hline
\end{tabular}

Sources: Fund staff estimates based on data from the Bank of Guyana. 
Table 28. Guyana: Commodity Composition of Exports

(Value in millions of U.S. dollars, volume in thousands of metric tons, and unit value in U.S. dollars per metric ton)

\begin{tabular}{|c|c|c|c|c|c|c|}
\hline & 1993 & 1994 & 1995 & 1996 & 1997 & $\begin{array}{l}\text { Prel. } \\
1998 \\
\end{array}$ \\
\hline Total exports (f.o.b.) & 404 & 447 & 496 & 575 & 592 & 547 \\
\hline Bauxite - value & 91 & 79 & 83 & 86 & 89 & 78 \\
\hline Volume & 2,050 & 1,996 & 1,971 & 2,100 & 2,200 & 2,086 \\
\hline Unit value & 44 & 40 & 42 & 41 & 41 & 37 \\
\hline Sugar - value & 116 & 116 & 126 & 151 & 133 & 129 \\
\hline Volume & 237 & 238 & 225 & 256 & 256 & 237 \\
\hline Unit value & 491 & 488 & 557 & 589 & 520 & 547 \\
\hline Rice - value & 33 & 56 & 77 & 95 & 84 & 73 \\
\hline Volume & 124 & 183 & 201 & 264 & 285 & 250 \\
\hline Unit value & 266 & 305 & 381 & 359 & 295 & 293 \\
\hline Gold - value & 100 & 128 & 95 & 104 & 137 & 124 \\
\hline Volume $(000 \mathrm{oz})$ & 279 & 359 & 275 & 290 & 411 & 417 \\
\hline Unit value (US\$/oz) & 358 & 357 & 344 & 359 & 333 & 298 \\
\hline Timber - value & 5 & 8 & 8 & 10 & 17 & 13 \\
\hline Volume (000 cu.m) & 19 & 39 & 36 & 42 & 102 & 86 \\
\hline Unit value (US\$/cu m) & 205 & 231 & 231 & 243 & 172 & 156 \\
\hline Other & 48 & 45 & 91 & 108 & 108 & 107 \\
\hline Re-exports (f.o.b.) & 12 & 16 & 17 & 22 & 23 & 22 \\
\hline
\end{tabular}

Sources: Bank of Guyana, Bureau of Statistics; and Fund staff estimates. 
Table 29. Guyana: Composition of Imports 1/

\begin{tabular}{|c|c|c|c|c|c|c|}
\hline & 1993 & 1994 & 1995 & 1996 & 1997 & $\begin{array}{l}\text { Prel. } \\
1998 \\
\end{array}$ \\
\hline \multicolumn{7}{|c|}{ (In millions of U.S. dollars) } \\
\hline Total imports, c.i.f. & 483.8 & 506.3 & 536.8 & 595.0 & 641.6 & 601.2 \\
\hline Capital goods & 169.2 & 110.4 & 187.7 & 174.1 & 184.8 & 162.6 \\
\hline Consumer goods & 102.8 & 82.3 & 114.1 & 168.9 & 181.5 & 193.7 \\
\hline Fuel and lubricants & 80.7 & 135.9 & 89.5 & 89.9 & 100.0 & 72.0 \\
\hline Other intermediate & 129.5 & 124.4 & 143.7 & 161.1 & 174.5 & 172.4 \\
\hline Miscellaneous & 1.6 & 53.3 & 1.8 & 1.0 & 0.8 & 0.5 \\
\hline \multicolumn{7}{|c|}{ (In percent change) } \\
\hline Total imports, c.i.f. & 9.3 & 4.7 & 6.0 & 10.8 & 7.8 & -6.3 \\
\hline Capital goods & -6.0 & -34.8 & 70.1 & 9.1 & 6.1 & -12.0 \\
\hline Consumer goods & 20.8 & -19.9 & 38.6 & 8.3 & 7.5 & 6.7 \\
\hline Fuel and lubricants & 2.3 & 68.4 & -34.1 & 13.4 & 11.2 & -28.0 \\
\hline Other intermediate & 66.5 & -3.9 & 15.5 & 9.3 & 8.3 & -1.2 \\
\hline Miscellaneous & -92.3 & 3231.3 & -96.7 & 8.0 & -20.0 & -37.5 \\
\hline
\end{tabular}

Sources: Bank of Guyana; and Fund staff estimates.

1/ Classification of imports from 1997 is based on the newly introduced ASYCUDA system and is not directly comparable to data prior to 1997. 
Table 30. Guyana: Services Account 1/

(In millions of U.S. dollars)

\begin{tabular}{|c|c|c|c|c|c|c|}
\hline & 1993 & 1994 & 1995 & 1996 & 1997 & $\begin{array}{l}\text { Prel. } \\
1998 \\
\end{array}$ \\
\hline Nonfactor services (net) & -7.8 & -11.2 & -26.3 & -32.8 & -23.2 & -32.0 \\
\hline Receipts & 115.3 & 120.7 & $\mathbf{1 3 3 . 5}$ & 138.8 & 148.1 & 141.8 \\
\hline Transportation & 29.4 & 26.7 & 33.1 & 34.4 & 3.3 & 2.8 \\
\hline Travel and tourism & 35.5 & 34.0 & 32.6 & 33.9 & 112.0 & 108.0 \\
\hline Communication services & 45.1 & 53.2 & 60.5 & 62.9 & 0.0 & 0.0 \\
\hline Government, n.i.e. & 3.5 & 3.6 & 3.9 & 4.1 & 0.0 & 0.0 \\
\hline Other & 1.9 & 3.2 & 3.4 & 3.6 & 27.0 & 25.0 \\
\hline Payments & 123.1 & 131.9 & 159.8 & 171.6 & 171.3 & 173.8 \\
\hline Transportation & 51.7 & 48.1 & 68.7 & 72.2 & 7.0 & 6.0 \\
\hline Travel and tourism & 12.5 & 23.0 & 21.1 & 22.1 & 62.0 & 63.0 \\
\hline Communication services & 14.0 & 22.1 & 38.5 & 40.4 & 1.0 & 0.8 \\
\hline Construction services & 15.8 & 9.0 & 5.7 & 6.0 & 0.0 & 0.0 \\
\hline Insurance services & 8.9 & 8.0 & 8.5 & 9.0 & 61.3 & 54.0 \\
\hline Nonmerchandise insurance & 4.8 & 5.0 & 5.4 & 5.6 & 0.0 & 0.0 \\
\hline Government, n.i.e & 6.9 & 4.3 & 4.3 & 4.5 & 0.0 & 0.0 \\
\hline Other & 8.4 & 12.4 & 7.6 & 11.8 & 40.0 & 49.9 \\
\hline Interest (net) & -79.2 & -72.2 & -75.2 & -53.9 & -69.8 & -52.5 \\
\hline Payments & -89.0 & -83.0 & -86.0 & -63.7 & -82.3 & -64.3 \\
\hline Receipts & 9.8 & 10.8 & 10.8 & 9.8 & 12.5 & 11.8 \\
\hline
\end{tabular}

Sources: Bank of Guyana; and Fund staff estimates.

1/ Classification from 1997 reflected the use of new Bank of Guyana survey forms and data are not directly comparable to previous years. 
Table 31. Guyana: External Public Debt and Debt Service

(In millions of U.S. dollars)

\begin{tabular}{|c|c|c|c|c|c|c|}
\hline & 1993 & 1994 & 1995 & 1996 & 1997 & $\begin{array}{r}\text { Prel. } \\
1998 \\
\end{array}$ \\
\hline Total public sector debt $1 /$ & 2,030 & 2,058 & 2,001 & 1,568 & 1,369 & $1, \mathbf{3 8 3}$ \\
\hline Government $2 / 3$ / & 1,228 & 1,250 & 1,188 & 1,201 & 1,084 & 1,114 \\
\hline Bank of Guyana 3/ & 802 & 808 & 813 & 367 & 285 & 270 \\
\hline Drawings & 104 & $\mathbf{5 3}$ & 55 & 112 & 91 & 71 \\
\hline Government $2 /$ & 92 & 40 & 40 & 86 & 67 & 58 \\
\hline Bank of Guyana & 13 & 13 & 14 & 26 & 24 & 12 \\
\hline Actual amortization & -58 & -59 & -71 & -71 & -74 & -72 \\
\hline Government $2 /$ & -42 & -33 & -34 & -34 & -34 & -37 \\
\hline Bank of Guyana & -16 & -26 & -37 & -36 & -39 & -35 \\
\hline Actual interest payments & 42 & 40 & 37 & 34 & 54 & 58 \\
\hline Government $2 /$ & 25 & 24 & 25 & 24 & 46 & 50 \\
\hline Bank of Guyana & 18 & 17 & 12 & 10 & 8 & 8 \\
\hline Actual debt service & 100 & 99 & 108 & 104 & 128 & 130 \\
\hline Government $2 /$ & 67 & 57 & 59 & 58 & 80 & 87 \\
\hline Bank of Guyana & 33 & 43 & 49 & 47 & 47 & 43 \\
\hline \multicolumn{7}{|l|}{ Memorandum items: } \\
\hline Multilateral debt (percent of total) & 45 & 44 & 47 & 62 & 69 & 70 \\
\hline Debt/GDP & 461 & 392 & 318 & 223 & 183 & 192 \\
\hline Actual debt-service ratio $4 / 5$ / & 19 & 17 & 17 & 15 & 17 & 19 \\
\hline Scheduled debt-service ratio 4/ & 26 & 30 & 27 & 23 & 16 & 15 \\
\hline Government debt service/revenue & 40 & 34 & 28 & 24 & 34 & 40 \\
\hline \multicolumn{7}{|l|}{ Government interest/ } \\
\hline current expenditure & 18 & 18 & 16 & 14 & 23 & 27 \\
\hline Effective interest rate $6 /$ & 2.1 & 2.0 & 1.8 & 1.9 & 3.7 & 4.2 \\
\hline
\end{tabular}

Sources: Data provided by the Guyanese authorities; World Bank Debtor Reporting System; and Fund staff estimates and projections.

1/Including valuation adjustment.

$2 /$ Including nonfinancial public enterprises.

3/ Reflects Paris Club stock-of-debt operation in May 1996.

$4 /$ In percent of exports of goods and nonfactor services.

5/ In 1997 the ratio reflects interest payments carried over from 1996 upon conclusion of bilateral agreements under the Paris Club framework. In 1998 the ratio reflects arrears payments.

6/Interest payments as a percent of average stock of debt. 1997 and 1998 reflects payments on interest arrears. 
Table 32. Guyana: External Public Sector Debt 1/

(In millions of U.S. dollars)

\begin{tabular}{|c|c|c|c|c|c|c|}
\hline & 1993 & 1994 & 1995 & 1996 & 1997 & $\begin{array}{r}\text { Prel. } \\
1998 \\
\end{array}$ \\
\hline Total external public debt & 2,030 & 2,058 & 2,001 & 1,568 & 1,369 & 1,383 \\
\hline \multicolumn{7}{|c|}{ Government and government guaranteed } \\
\hline medium- and long-term debt & 1,228 & 1,250 & 1,188 & 1,201 & 1,084 & 1,114 \\
\hline \multicolumn{7}{|l|}{ Of which } \\
\hline Bilateral & 466 & 494 & 444 & 461 & 384 & 383 \\
\hline \multicolumn{7}{|l|}{ Of which } \\
\hline China & 28 & 31 & 24 & 30 & 30 & 30 \\
\hline Germany & 41 & 37 & 32 & 18 & 18 & 18 \\
\hline Trinidad and Tobago & 101 & 95 & 107 & 177 & 177 & 177 \\
\hline United Kingdom & 173 & 207 & 173 & 73 & 73 & 73 \\
\hline United States & 24 & 26 & 25 & 33 & 33 & 33 \\
\hline Multilateral & 588 & 590 & 622 & 678 & 664 & 701 \\
\hline $\mathrm{CDB}$ & 60 & 55 & 57 & 51 & 51 & 51 \\
\hline IBRD & 40 & 34 & 38 & 27 & 19 & 16 \\
\hline IDA & 169 & 177 & 213 & 213 & 220 & 237 \\
\hline IDB & 242 & 253 & 245 & 300 & 301 & 322 \\
\hline OPEC & 18 & 21 & 23 & 24 & 19 & 18 \\
\hline Other & 59 & 50 & 46 & 63 & 54 & 56 \\
\hline Bank of Guyana debt & 802 & 808 & 813 & 367 & 285 & 270 \\
\hline Bilateral & 478 & 486 & 499 & 69 & 11 & 7 \\
\hline Multilateral & 324 & 322 & 314 & 298 & 275 & 263 \\
\hline CMCF & 145 & 143 & 139 & 130 & 118 & 108 \\
\hline IMF & 179 & 179 & 175 & 168 & 157 & 154 \\
\hline
\end{tabular}

Sources: Ministry of Finance; Bank of Guyana; and Fund staff estimates.

1/ The stock of debt outstanding at end-year, reflects Paris Club stock-of-debt operation in May 1996. 
Table 33. Guyana: Effective Exchange Rates and Related Series

(Index: $1990=100$ )

\begin{tabular}{|c|c|c|c|c|c|c|}
\hline & \multirow{3}{*}{$\begin{array}{r}\text { Real } \\
\text { Effective } \\
\text { Exchange } \\
\text { Rate } 1 / 2 / \\
\end{array}$} & \multirow{3}{*}{$\begin{array}{r}\text { Nominal } \\
\text { Effective } \\
\text { Exchange } \\
\text { Rate 2/ }\end{array}$} & \multirow{3}{*}{$\begin{array}{r}\text { Relative } \\
\text { Consumer } \\
\text { Prices } \\
\end{array}$} & \multirow{3}{*}{$\begin{array}{r}\text { Exchange } \\
\text { Rates in } \\
\text { Terms of } \\
\text { U.S. Dollars 1/ } \\
\end{array}$} & \multirow{2}{*}{\multicolumn{2}{|c|}{ Consumer Prices }} \\
\hline & & & & & & \\
\hline & & & & & $\begin{array}{r}\text { Seasonally } \\
\text { Adjusted } \\
\end{array}$ & $\begin{array}{l}\text { Seasonally } \\
\text { Unadjusted }\end{array}$ \\
\hline 1993 & 102.128 & 49.413 & 199.654 & 37.104 & 279.458 & 279.316 \\
\hline 1994 & 100.927 & 50.485 & 193.031 & 34.000 & 314.028 & 314.022 \\
\hline 1995 & 102.577 & 48.134 & 205.684 & 33.084 & 352.483 & 352.400 \\
\hline 1996 & 110.910 & 49.920 & 214.458 & 33.450 & 377.373 & 377.394 \\
\hline 1997 & 116.934 & 52.001 & 217.055 & 33.028 & 390.849 & 390.813 \\
\hline 1998 & 117.747 & 50.956 & 223.128 & 31.243 & 408.804 & 408.737 \\
\hline \multicolumn{7}{|l|}{1994} \\
\hline 1 & 105.013 & 52.497 & 194.091 & 35.786 & 298.642 & 295.607 \\
\hline II & 99.365 & 51.164 & 187.457 & 34.031 & 302.896 & 302.366 \\
\hline III & 99.363 & 49.508 & 193.739 & 33.206 & 322.422 & 325.188 \\
\hline IV & 99.966 & 48.772 & 197.839 & 32.978 & 332.152 & 332.926 \\
\hline \multicolumn{7}{|l|}{1995} \\
\hline I & 101.022 & 48.239 & 202.164 & 32.835 & 342.433 & 340.105 \\
\hline II & 99.611 & 46.821 & 205.365 & 32.709 & 350.927 & 349.577 \\
\hline III & 102.452 & 48.131 & 205.462 & 33.109 & 353.695 & 356.335 \\
\hline IV & 107.222 & 49.344 & 209.744 & 33.682 & 362.875 & 363.583 \\
\hline \multicolumn{7}{|l|}{1996} \\
\hline I & 109.261 & 49.703 & 212.193 & 33.482 & 369.694 & 367.795 \\
\hline II & 111.488 & 50.114 & 214.742 & 33.482 & 376.942 & 375.533 \\
\hline III & 111.496 & 49.944 & 215.493 & 33.482 & 380.355 & 382.879 \\
\hline IV & 111.393 & 49.917 & 215.405 & 33.366 & 382.503 & 383.369 \\
\hline \multicolumn{7}{|l|}{1997} \\
\hline 1 & 114.699 & 51.358 & 215.585 & 33.247 & 385.285 & 383.564 \\
\hline II & 115.702 & 51.691 & 216.077 & 33.122 & 387.820 & 386.307 \\
\hline III & 117.787 & 52.404 & 216.966 & 32.934 & 391.826 & 394.145 \\
\hline IV & 119.550 & 52.552 & 219.591 & 32.809 & 398.466 & 399.236 \\
\hline \multicolumn{7}{|l|}{1998} \\
\hline$I$ & 121.820 & 53.196 & 221.088 & 32.730 & 403.112 & 401.489 \\
\hline II & 121.509 & 52.343 & 224.079 & 31.885 & 410.411 & 408.933 \\
\hline III & 118.670 & 51.486 & 222.474 & 31.290 & 408.848 & 411.088 \\
\hline IV & 108.987 & 46.801 & 224.869 & 29.426 & 412.845 & 413.439 \\
\hline
\end{tabular}

Sources: Data provided by the Guyana authorities; and IMF, Information Notice system.

1/ Increases mean appreciation.

2/ Using seasonally adjusted price indices. 